\title{
May 21, 1895. \\ Lt.-Col. H. H. Godwin-Austen, F.R.S., Vice-President, in the Chair.
}

Mr. Sclater made some remarks on the Zoological Institutions which he had recently visited in Cairo. These were the new Zoological Garden at Gizeh, the Zoological Collection in the Medical School at Cairo, and the Ostrich Farm at Matariyeh.

Part of the former Palace-Garden at Gizeh had recently been appropriated by the Egyptian Government as a Zoological Garden, of which a young Englishman, Mr. Jennings Bramley, had been appointed Manager. The Institution was at present quite in its infancy, but had the great advantage of a beautiful garden of 20 acres, well stocked with fine trees and shrubs, and furnished with an abundant water-supply. The small collection already made consisted principally of well-known Egyptian animals, with a certain number of Oriental species, obtained from ships passing through the Suez Canal.

Amongst the Egyptian animals, besides the ordinary Gazella dorcas, of which there were many specimens, Mr. Sclater had examined individuals of both sexes of another Gazelle, said to have been obtained in the Libyan Desert. This belonged to the group with long straight horns, allied to G. cuvieri and G. leptoceros ( $c f$. Brooke, P.Z.S. 1873, p. 543). Mr. Sclater was endeavouring to obtain more information respecting it, but there could be no doubt of the existence of a second species of Gazelle in Egypt.

Amongst the birds in the gardens, Mr. Sclater had noticed two fine specimens of Rüppell's Griffon (Gyps rueppelli), said also to have been obtained from the Western Desert. This species was not recognized in Shelley's 'Birds of Egypt;' and it was rather surprising to meet with it so far north.

The only zoological collection in Cairo was that of the Government School of Medicine, under the care of Dr. Innes. It was at present in an undeveloped condition, but contained a series of Egyptian animals along with others from various parts of the world, intended originally for educational purposes. It was hoped with Dr. Anderson's promised assistance, and aid from other quarters, to make considerable additions to the Egyptian series. There could be no doubt that the capital of Egypt ought to contain a good exhibition of the native animals.

The Ostrich Farm at Matariyeh, near the Khedive's palace at Kubbeh, was, in Mr. Sclater's opinion, one of the most interesting sights in Cairo. It was said to have been commenced with some twenty birds from two sources about fifteen years ago, and now contained about 1400 Ostriches of different ages. The birds were placed in small compartments enclosed by mud walls ten feet high, and arranged according to age, both sexes being kept together. After four or five years, when fully adult and showing signs of 


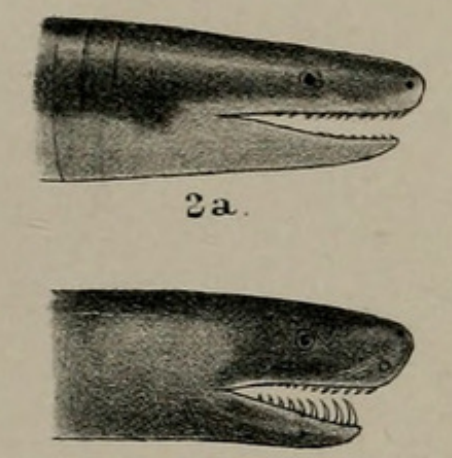

$1 a$

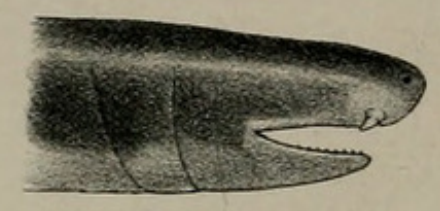

$3 a$.

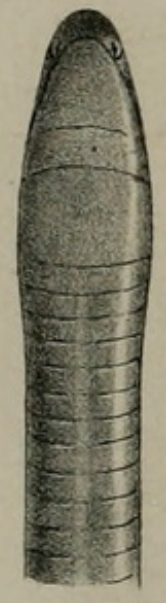

$3 b$.
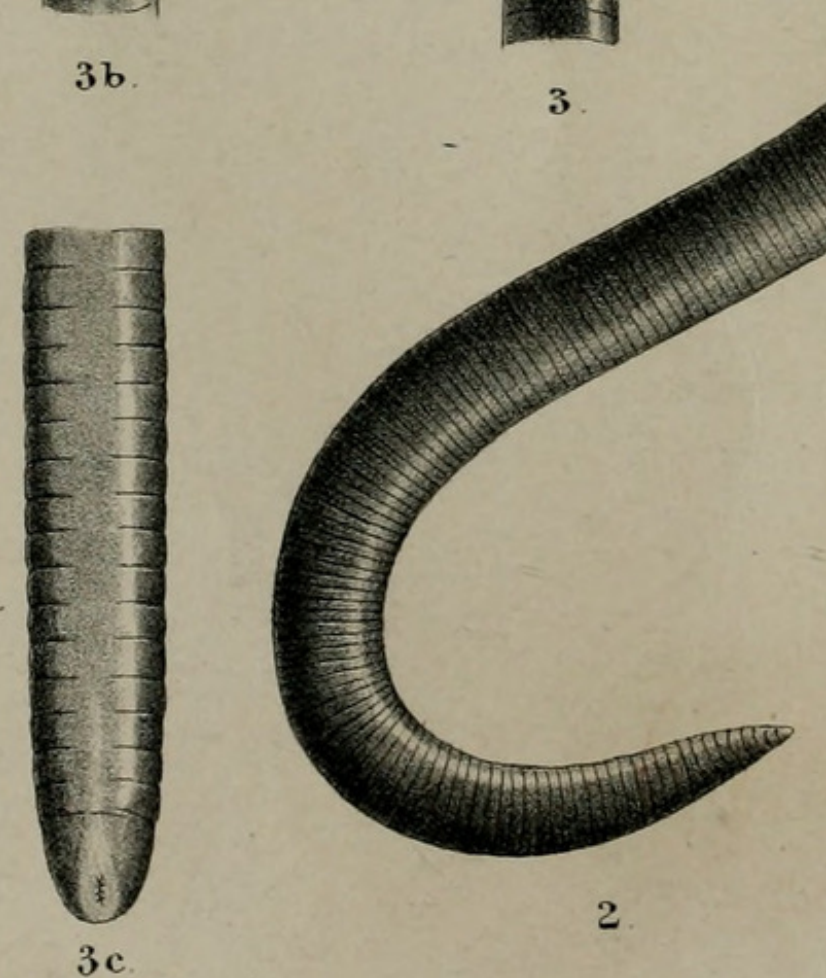

J. Green \& R.E.M. del et lith.

1. CACILIA BUCKLEYI 2.RHINATREMA BICOLOR.

Mintern Bros mp. 3. SCOLECOMORPHUS KIRKII. 


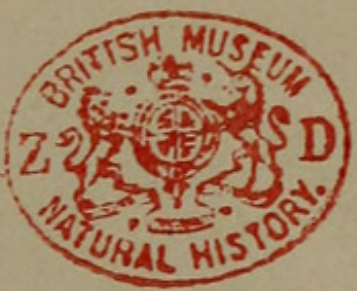




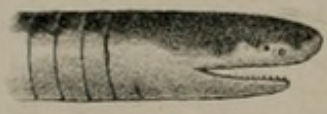

4.a

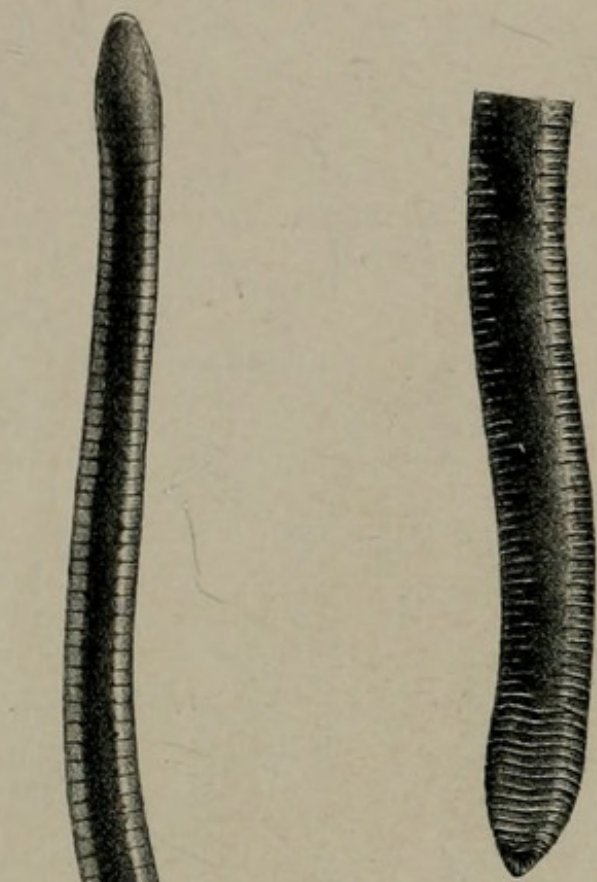

$1 b$.

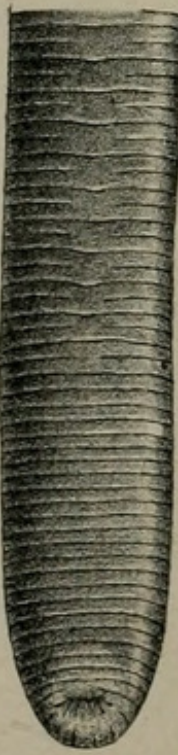

4

$2 b$

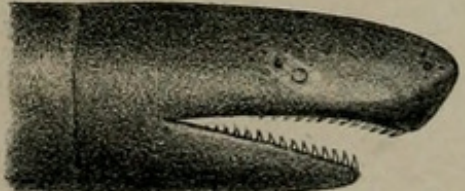

$2 a$

2

1 .

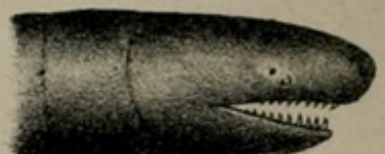

32
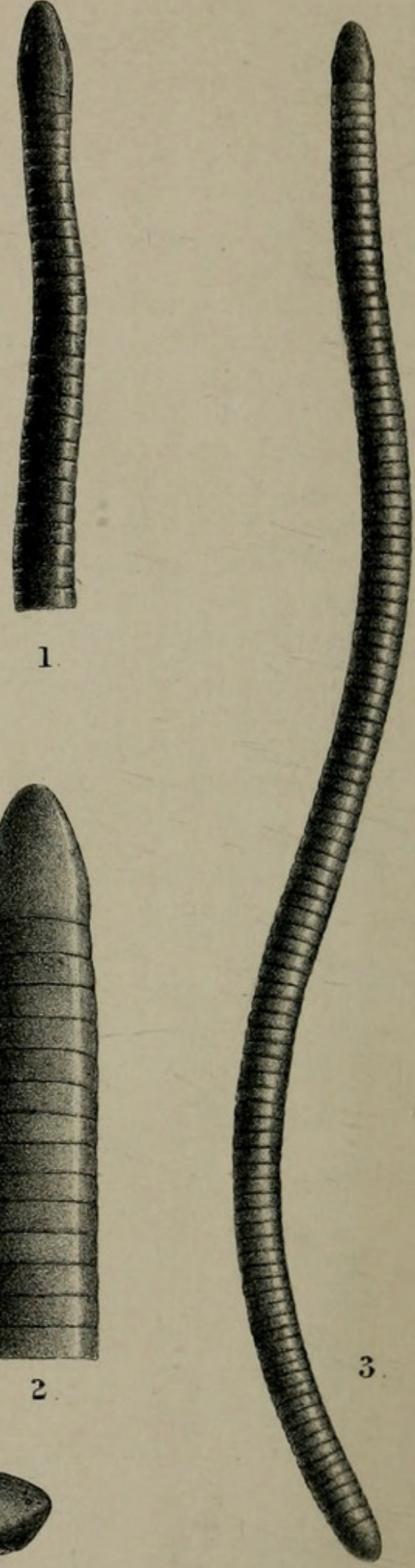

J. Green \& RE M del et lith

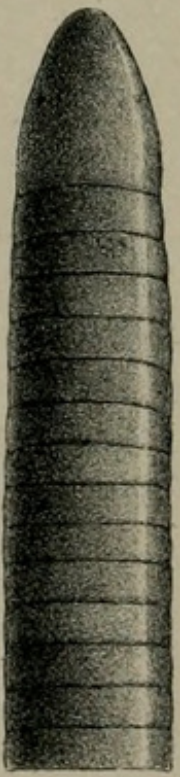

1. GEOTRYPETES PETERSII. 2. CRYPTOPSOPHIS MULTIPLICATUS. 3.SIPHONOPS HARDYI 4.BDELLOPHIS VITTATUS. 
wishing to breed, a pair was selected and put together in a separate enclosure. Here the eggs were laid, and the birds, as Mr. Sclater was assured, took turns in sitting; but many of the eggs were hatched in incubators. In one compartment were contained 11 examples (6 males and 5 females) of the very distinct Somali Ostrich, Struthio molybdophanes. The remainder were all of the typical northern form, S. camelus, with red naked skin; and amongst them were many very fine birds, quite as large as the well-known specimen lately in the Zoological Society's Gardens, from Western Africa, deposited by the Queen.

Mr. Howard Saunders, F.Z.S., exhibited, on behalf of Mr. R. M. Barrington, a hybrid Duck shot in March last on the Moy Estuary, in the West of Ireland. It was evidently a cross between the Wigeon (Mareca penelope) and some other species; the other parent being supposed to have been the Gadwall (Chaulelasmus streperus) by some authorities, while others inclined to the Pintail (Dafila acuta), and others again to the Teal (Querquedula crecca).

Mr. Tegetmeier exhibited and made remarks on a specimen of a Rook (Corvus frugilegus), one of a number produced in one Rookery, in which every feather of the entire plumage was tipped or spangled with white.

The following papers were read :-

1. A Synopsis of the Genera and Species of Apodal Batrachians, with Description of a new Genus and Species (Bdellophis vittatus). By G. A. Boulenger, F.R.S.

\section{(Plates XXIII. \& XXIV.)}

[Received April 19, 1895.]

Whilst describing a new Cæcilian it has occurred to me that a revised list of the 42 species of this order now known would prove useful to the student of these interesting but still very imperfectly known Batrachians. Since the publication of the last revision (Cat. Batr. Grad. \&c. 1882), in which 11 genera and 32 species were defined, many new species have been described and numerous additions and corrections have been made to the synonymy by Cope, Boettger, Vaillant, Stejneger, and myself. These alterations have all been worked into the list now offered for publication to the Society. In order to facilitate identifications, synopses of the genera and species have been inserted. The prefix of an asterisk indicates that the species is represented in the British Museum.

Proc. Zoou, Soc,-1895, No. XXVI, 
I still think it desirable to retain the Apoda as an order distinct from the Caudata, in spite of the views expressed by Prof. Cope and the Drs. Sarasin. If the absence of limbs and the reduction of the tail were the only characteristic of the group, I should of course not hesitate to unite the Cæcilians with the Urodeles; but, to say nothing of the scales, the Cæcilian skull presents features which are not shared by any of the tailed Batrachians, and the order can be defined by the cranial characters alone. The resemblance of the larval Ichthyophis to Amphiuma is, after all, superficial ; and although, as I believe, the Apoda and Caudata may have evolved from a common stock, Amphiuma is certainly not the connecting form between the two, as Prof. Cope would have it, for we cannot well assume the scales, lost in the Urodeles, to have reappeared in the Cæcilians.

I wish, furthermore, to justify the use of the name Apoda for the order often designated as Pseudophidia, Batrachophidia, Gymnophiona, or Peromela. Unless obviously misleading, which is not the case in the present instance, the first-proposed name should supersede all others for higher groups as well as for genera and species, and "Apoda" has the benefit of the law of priority. In the first subdivision of the Batrachians into two families by Duméril in 1806 (Zool. Anal. pp. 90-94) these groups are termed "Anoures" and "Urodèles" in French, Ecaudati and Caudati in Latin. When Duméril's pupil, Oppell, in 1811 (Ordn. Rept. p. 72), added the Crcilians, he named the three groups Apoda, Ecaudata, and Caudata. The Latin form being the only one entitled to recognition in zoological nomenclature, it follows that the last mentioned names should be adopted for the three orders into which Batrachians are divided.

\section{Order APODA.}

No limbs. Tail vestigial or absent. Frontal bones distinct from parietals; palatines fused with maxillaries. Male with an intromittent copulatory organ.

\section{Fam. CжCILIIDж.}

\section{Synopsis of the Genera.}

I. Cycloid scales imbedded in the skin.

A. Eyes distinct or concealed under the skin.

1. Two series of teeth in the lower jaw.

a. Squamosal and parietal bones in contact.

Tentacle conical, below and in front of the eye, usually much nearer the latter than the nostril; circular folds angulate on the belly

Tentacle globular, surrounded by a groove, in front of the eye

Tentacle valvular, tentacular groove horseshoe-shaped, posterior to the nostril

Tentacle valvular, tentacular groove horseshoe-shaped, below the nostril

1. Iснтнуорніs.

2. DeRMophis.

3. HYPOGEOPHIS.

4. Cescilia, 
$b$. Squamosals separated from parietals.

Tentacle valvular, close to the eye

Tentacle valvular, below and behind the nostril

Tentacle conical, below the nostril.

2. A single series of teeth in the lower jaw; tentacle globular, in front of the eye

B. Eyes below the cranial bones; squamosals in contact with parietals; tentacle globular.

Tentacle below and a little behind the nostril

Tentacle nearer the commissure of the jaws than the nostril

II. No scales.

A. Eyes distinct or concealed under the skin.

1. Two series of teeth in the lower jaw.

Parietals and squamosals in contact

11. Typhlonectes.

Parietals separated from squamosals.

12. Chthonerpeton.

2. A single series of teeth in the lower jaw.

Parietals and squamosals in contact

Parietals separated from squamosals.

13. SipHoNops.

14. Bdellophis.

\section{Rhinatrema. \\ 6. Geotrypetes. \\ 7. URÆOTYPHLUS.}

8. Cryptopsophis. 10. GyMNopis.

B. Eyes below the cranial bones.

Two series of teeth in the lower jaw ; parietals and squamosals in contact

A single series of teeth in the lower jaw; parietals separated from squamosals

15. Gegenophis. 16. SCOLECOMORPIIUS

\section{IohthYopHis.}

Ichthyophis, Fitzing. N. Class. Rept. p. 36 (1826); Peters, Mon. Berl. Ac. 1879 , p. 931 ; Bouleng. Cat. p. 89 (1882).

Epicrium, Wagl. Isis, 1828, p. 743, and Syst. Amph. p. 198 (1830) ; Dum. \& Bibr. viii. p. 285 (1841); A. Dum. Mém. Soc. Cherb. ix. 1863, p. 319.

\section{Synopsis of the Species.}

Snout as long as the distance between the eyes; a yellow lateral band

Snout shorter than the distance between the eyes; no lateral band

1. glutinosus.

2. monochrous.

\section{*1. IсHтHYopHIS gLUTINosus.}

Cacilia glutinosa, Linn. Mus. Ad. Frid. p. 19, pl. iv. fig. 1 (1754), and S. N. i. p. 393 (1766); Daud. Rept. vii. p. 418 (1803); Peters, Mon. Berl. Ac. 1864, p. 303.

Cacilia viscosa, Latr. Rept. iv. p. 238 (1802)

Ichthyophis hasseltii, Fitzing. N. Class. p. 63 (1826).

Ccecilia hypocyanea, Hasselt, Isis, 1827, p. 565 ; Müll. Zeitschr.

f. Physiol. iv. 1831, p. 195, and Arch. Anat. Phys. 1835, p. 391, pl. viii. figs. 12-14; Schleg. Abbild. p. 119, pl. xxxix. fig. 1 (1844).

Epicrium hasseltii, Wagl. Isis, 1828, p. 743.

Epicrium glutinosum, Dum. \& Bibr. viii. p. 286 (1841); A. Dum. Mém. Soc. Cherb. ix. 1863, p. 319 ; Günth. Rept. Brit. Ind. p. 441 (1864). 
Ichthyophis glutinosus, Cantor, Cat. Mal. Rept. p. 138 (1847); Gray, Cat. p. 60 (1850); Peters, Mon. Berl. Ac. 1879, p. 931, pl. - . figs. 1 \& 3 ; Bouleng. Cat. p. 89, pl. iv. fig. 2 (1882); Sarasin, Nat. Forsch. Ceylon, ii. (1887-1890); Bouleng. Ann. Mus. Genova, (2) v. 1887 , p. 423 , pl. iv. fig. 4 , and Faun. Ind., Rept. p. 515 (1890).

Ichthyophis beddomii, Peters, Mon. Berl. Ac. 1879, p. 932, pl. - - fig. 4 .

Southern India ; Ceylon ; Eastern Himalayas ; Assam ; Burma ; Indo-China; Malay Peninsula ; Sumatra; Borneo; Java.

*2. IсHтHYOPHIS MONOCHROUS.

Ichthyophis glutinosus, var., Cantor, Cat. Mal. Rept. p. 137 (1847).

Epicrium monochroum, Bleek. Nat. Tijdschr. Nederl. Ind. xvi. 1858, p. 188; Günth. Rept. Brit. Ind. p. 443 (1864).

Ichthyophis monochrous, Peters, Mon. Berl. Ac. 1879, p. 932 ; Bouleng. Cat. p. 91, pl. iv. fig. 1 (1882), and Faun. Ind., Rept. p. 517 (1890).

Western Ghats of India, from Bombay to Travancore ${ }^{1}$; Sikkim ; Singapore; Sumatra ; Borneo; Java.

\section{Dermophis.}

Siphonops, part., Dum. \& Bibr. viii. p. 281 (1841); A. Dum. Mém. Soc. Cherb. ix. 1863, p. 317.

Dermophis, Peters, Mon. Berl. Ac. 1879, p. 937 ; Bouleng. Cat. p. 97 (1882).

\section{Synopsis of the Species.}

I. Diameter of body 46 times in total length; 170 folds ; tentacle in front of, and scarcely below, the eye

1. albiceps.

II. Diameter of body 20 to 30 times in total length; 125170 folds.

Snout rounded, as long as the distance between the eyes

Snout rounded, a little longer than the distance between the eyes

Snout acuminate; the distance between tentacle and nostril four to five times that between tentacle and eye

2. mexicanus. 3. gregorii.

III. Diameter of body 19 times in total length; 95 folds ...

4. thomensis.

5. crassus.

*1. DeRMophis ALBICEPS.

Dermophis albiceps, Bouleng. Cat. p. 98, pl. viii. fig. 1 (1882). Ecuador.

*2. DeRmophis mexicanus.

Siphonops mexicanus, Dum. \& Bibr. viii. p. 284 (1841); Gray, Cat. p. 59 (1850); A. Dum. Mém. Soc. Cherb. ix. 1863, p. 23,

I A fine specimen from Maduvangaud, Travancore, presented by Mr. H. S, Ferguson, measures 500 millim. 
pl. i. fig. 10 ; Brocchi, Miss. Sc. Mex., Batr. p. 120, pl. xxi. fig. 2 (1882).

Dermophis mexicanus, Peters, Mon. Berl. Ac. 1879, p. 937, pl. - - fig. 6 ; Bouleng. Cat. p. 98, pl. viii. fig. 2 (1882).

Mexico and Central America.

*3. Dermophis GregoriI.

Dermophis gregorii, Bouleug. P. Z. S. 1894, p. 646, pl. xl. fig. 4 (1895).

Ngatana, East Africa.

*4. DeRmophis thomensis.

Siphonops thomensis, Bocage, Jorn. Se. Lisb. iv. 1873, p. 224.

Siphonops brevirostris, Peters, Mon. Berl. Ac. 1874, p. 617, pl. i. fig. 2.

Dermophis brevirostris, Peters, Mon. Berl. Ac. 1879, p. 937.

Dermophis thomensis, Peters, l. c. p. 938, and 1880, p. 223 ; Bouleng. Cat. p. 98 (1882); Greef, Sitzb. Ges. Marburg, 1884, p. 15 ; Bedriaga, Amph. \& Rept. I. Guin.p. 13 (1892).

S. Thomé, Gulf of Guinea.

\section{Dermophis crassus.}

Dermophis crassus, Cope, Proc. Am. Philos. Soc. xxii. 1885, p. 184.

Bolivia ; Eastern Peru.

The systematic position of the following species, provisionally referred to Dermophis by Cope, is very doubtful :-

Siphonops syntremus, Cope, Proc. Ac. Philad. 1866, p. 129.

Typhlonectes? syntremus, Peters, Mon. Berl. Ac. 1879, p. 941.

Dermophis syntremus, Cope, Proc. Am. Philos. Soc. xxii. 1885, p. 171.

Belize.

\section{HYPOGEOPHIS.}

Cacilia, part., Dum. \& Bibr. viii. p. 274 (1841); A. Dum. Mém. Soc. Cherb. ix. 1863 , p. 311.

Hypogeophis, Peters, Mon. Berl. Ac. 1879, p. 936 ; Bouleng. Cat. p. 96 (1882).

\section{Synopsis of the Species.}

Tentacle much nearer the nostril than the eye; 100 folds Tentacle much nearer the nostril than the eye; $105-130$ folds... Tentacle not or but little nearer the nostril than the eye; 175 folds

1. guentheri. 2. rostratus. 3. alternans.

*1. HYPogeophIS GUENTHERI.

Hypogeophis guentheri, Bouleng. Cat. p. 96, pl. vii. fig. 1 (1882). Zanzibar. 
*2. Hypogeophis rostratus.

Cacilia rostrata, Cuv. R. A. 2nd ed. ii. p. 100 (1829); Dum. \& Bibr. viii. p. 279 (1841); Peters, Mon. Berl. Ac. 1877, p. 456.

Hypogeophis rostratus, Peters, Mon. Berl. Ac. 1879, p. 936, and Sitzb. Ges. naturf. Fr. 1880 , p. 53 ; Bouleng. Cat. p. 96, pl. vii. fig. 2 (1882); Stejneg. Proc. U. S. Nat. Mus. xvi. 1894, p. 738.

Seychelles.

*3. Hypogeophis alternans.

Hypogeophis alternans, Stejneg. Proc. U. S. Nat. Mus. xvi. 1894, p. 739 .

Seychelles.

\section{CесіLIA.}

Caccilia, part., Linn. S. N. i. p. 229 (1766).

Cacilia, Wagl. Syst. Amph. p. 198 (1830); Dum. \& Bibr. viii. p. 274 (1841); A. Dum. Mém. Soc. Cherb. ix. 1863, p. 311 ; Peters, Mon. Berl. Ac. 1879, p. 934 ; Bouleng. Cat. p. 93 (1882).

\section{Synopsis of the Species.}

I. Total length not 60 times greatest diameter of body.

135-150 circular folds, last 40 to 50 not interrupted on the dorsal line.

115-140 circular folds, last 16 to 20 not interrupted on the dorsal line

1. tentaculata.

175 circular folds, all complete

2. isthmica.

3. buckleyi.

II. Total length more than 60 times greatest diameter of body. 207-209 circular folds, nearly all complete 160-170 circular folds, interrupted on the dorsal and ventral lines 210-255 circular folds, interrupted on the dorsal and ventral lines

4. polyzona.

5. pachynema.

6. gracilis.

*1. Cecilita tentaculata.

Caccilia, Linn. Amœn. Acad. i. p. 489, pl. xvii. fig. 1 (1754).

Cacilia tentaculata, part., Linn. Mus. Ad. Frid. p. 19 (1754), and S. N. i. p. 393 (1766).

Cacilia tentaculata, Shaw, Zool. iii. p. 599, pl. exxxvi. (1802); Peters, Mon. Berl. Ac. 1879, p. 934; Bouleng. Cat. p. 93 (1882). Cacilia albiventris, Daud. Rept. vii. p. 423, pl. xcii. fig. 1 (1803); Dum. \& Bibr. viii. p. 277 (1841).

Guianas.

\section{*2. Cecilita isthmica.}

Cacilia rostrata (non Cuv.), Günth. P. Z. S. 1859, p. 417.

Cacilia isthmica, Cope, Proc. Am. Philos. Soc. xvii. 1877, p. 91; Bouleng. Cat. p. 94, pl. vi. fig. 1 (1882).

Cacilia guentheri, Peters, Mon. Berl. Ac. 1879, p. 936.

Cacilia pachynema (non Gthr.), Bouleng. Bull. Soc. Zool. France, 1880 , p. 48.

Jsthmus of Darien; Ecuador. 
*3. Chomia buckleyi. (Plate XXIII. fig. 1.)

Caceilia buckleyi, Bouleng. Ann. \& Mag. N. H. (5) xiii. 1884, p. 398.

Intac, Ecuador.

*4. Cecilia polyzona.

Cacilia polyzona, Fischer, Mon. Berl. Ac. 1879 , p. 937, and Arch. f. Nat. 1880, p. 215, pl. viii. figs. 1-4; Bouleng. Cat. p. 94 (1882).

Colombia.

*5. Cefoilia pachynema.

Cacilia pachynema, Günth. P. Z. S. 1859, p. 417 ; Peters, Mon. Berl. Ac. 1879 , p. 935 ; Bouleng. Cat. p. 95, pl. vi. fig. 2 (1882).

W. Ecuador.

*6. Cecithia gracilis.

Caccilia tentaculata, part., Linn. Mus. Ad. Frid. p. 19, pl. v. fig. 2 (1754), and S. N. i. p. 393 (1766).

Cacilia gracilis, Shaw, Zool. iii. p. 597 (1802); Gray, Cat.p. 57 (1850); Günth. P. Z. S. 1859 , p. 417 ; Peters, Mon. Berl. Ac. 1879 , p. 937 ; Bouleng. Cat. p. 95 (1882).

Cacilia lumbricoidea, Daud. Rept. vii. p. 420, pl. xcii. fig. 2 (1803); Dum. \& Bibr. viii. p. 275 (1841); A. Dum. Mém. Soc. Cherb. ix. 1863, p. 313.

Guianas, N. Brazil.

\section{Rhinatrema.}

Rhinatrema, Dum. \& Bibr. viii. p. 288 (1841); A. Dum. Mém. Soc. Cherb. ix. 1863 , p. 320 ; Vaill. C. R. Ac. Sc. exx. 1895, p. 460.

Epicrionops, Bouleng. Ann. \& Mag. N. H. (5) vi. 1883, p. 202.

Synopsis of the Species.

340 cireular folds

1. bivittatum.

245 circular folds

2. bicolor.

\section{Rhinatrema bivititatum.}

Cacilia bivittata, Cuv. R. A. 2nd ed. ii. p. 100 (1829); Guér. Icon. R. A., Rept. pl. xxv. fig. 2 (18-?).

Rhinatrema bivittatum, Dum. \& Bibr. viii. p. 288, pl. lxxxv. fig. 4 (1841); Peters, Mon. Berl. Ac. 1879, p. 942, pl. - . fig. 2; Vaill. C. R. Ac. Sc. exx. 1895, p. 461.

Cayenne.

*2. Rhinatrema bicolor. (Plate XXIII. fig. 2.)

Epicrionops bicolor, Bouleng. Ann. \& Mag. N. H. (5) xi. 1883, p. 202.

Rhinatrema bicolor, Vaill. C. R. Ac. Sc. cxx. 1895, p. 461. 
Intac, Ecuador.

Prof. Vaillant has recently pointed out that the late Prof. Peters was mistaken in identifying the type specimen of $C$. bivittata, which he had an opportunity of examining, with Ichthyophis glutinosus, and that the genus Rhinatrema is in every respect identical with Epicrionops, established by me in 1883, at a time when I had no reason to question the correctness of Peters's identification. It is now to me even a matter of doubt whether the two species mentioned above are really distinct, considering the amount of variation in the number of folds in Ichthyophis.

\section{Geotrypetes.}

Geotrypetes, Peters, Sitzb. Ges. naturf. Fr. Berl. 1880, p. 55 ; Bouleng. Ann. \& Mag. N. H. (6) xv. 1895, p. 329.

1*. Geotrypetes Petersit. (Plate XXIV. fig. 1.)

Hypogeophis seraphini (non A. Dum.), Peters, Mon. Berl. Ac. 1879 , p. 937.

Geotrypetes seraphini, Peters, Sitzb. Ges. naturf. Fr. 1880, p. 55.

Geotrypetes petersii, Bouleng. Ann. \& Mag. N. H. (6) xv. 1895, p. 329.

West Africa (Lagos, Cameroon).

\section{URæOTYPHLUS.}

Cacilia, part., Dum. \& Bibr. viii. p. 274 (1841); A. Dum. Mém. Soc. Cherb. ix. 1863 , p. 311.

Urcootyphlus, Peters, Mon. Berl. Ac. 1879, p. 933 ; Bouleng. Cat. p. 91 (1882).

\section{Synopsis of the Species.}

Snout moderately prominent, as long as the distance between the eyes ; $120-130$ folds

Snout moderately prominent, as long as the distance hetween the eves; 200 folds

Snout very prominent, longer than the distance between the eyes; $240-260$ folds

1. seraphini.

2. oxyurus.

3. malabaricus.

\section{*1. URAOTYPHLUS SERAPHINI.}

Cacilia seraphini, A. Dum. Arch. Mus. x. 1859 , p. 222 , and Mém. Soc. Cherb. ix. 1863, p. 314.

Urceotyphlus africanus, Bouleng. Cat. p. 92, pl. v. fig. 1 (1882). Urceotyphlus seraphini, Bouleng. Ann. \& Mag. N. H. (6) xv. 1895 , p. 328.

Gaboon.

*2. URAOTYPhLUS OXYURUS.

Caccilia oxyura, Dum. \& Bibr. viii. p. 280 (1841); A. Dum. Mém. Soc. Cherb. ix. 1863, p. 22, pl. i. tig. 8 ; Günth. Rept. Brit. Ind. p. 443 (1864).

Urcoot!phlius vxyurus, Peters, Mon. Berl. Ac. 1879, p. 933, and 
Sitzb. Ges. naturf. Fr. 1881, p. 90 ; Bouleng. Cat. p. 92, pl. v. fig. 2 (1882), and Faun. Ind., Rept. p. 517 (1890).

Malabar.

*3. UReotyphlús malabaricus.

Cacilia malabarica, Beddome, Madr. Monthly Journ. Med. Sc. 1870 , p. 176.

Urceotyphlus malabaricus, Peters, Mon. Berl. Ac. 1879 , p. 933 ; Bouleng. Cat. p. 92, pl. v. fig. 3 (1882), and Faun. Ind., Rept. p. 518 (1890).

Malabar.

8. Cryptopsophis.

Cryptopsophis, Bouleng. Ann. \& Mag. N. H. (5) xii. 1883, p. 166.

*1. Cryptopsophis multiplicatus. (Plate XXIV. fig. 2.)

Cryptopsophis multiplicatus, Bouleng. $l$. $c$.

Seychelles.

9. Herpele.

Ccccilia, part., Gray, Cat. p. 59 (1850); A. Dum. Mém. Soc. Cherb. ix. 1863, p. 311.

Herpele, Peters, Mon. Berl. Ac. 1879, p. 939; Bouleng. Cat. p. 100 (1882).

Synopsis of the Species.

130-150 circular folds

1. squalostoma.

200-206 circular folds.

2. ochrocephala.

*1. Herpele squalostoma.

Cacilia squalostoma, Stutchbury, Trans. Linn. Soc. xvii, 1850, p. 362 ; Gray, Cat. p. 59 (1850); A. Dum. Arch. Mus. x. 1859, p. 222, and Mém. Soc. Cherb. ix. 1863, p. 314.

Herpele squalostoma, Peters, Mon. Berl. Ac. 1879, p. 939, pl. fig. 8 ; Bouleng. Cat. p. 101, pl. ix. fig. 1 (1882).

Gaboon.

*2. Herpele ochrocephala.

Cacilia ochrocephala, Cope, Proc. Ac. Philad. 1866, p. 132 ; Bouleng. Cat. p. 94 (1882) ; Brocchi, Miss. Sc. Mex., Batr. p. 119, pl. xxi. fig. 1 (1882).

Herpele ochrocephala, Cope, Proc. Am. Philos. Soc. xxii. 1885, p. 171.

Panama.

10. Grunopis.

Rhinatrema, part., A. Dum. Mém. Soc. Cherb. ix. 1863, p. 320. Gymnopis, Peters, Mon. Berl. Ac. 1874, p. 216, and 1879, p. 938 ; Bouleng. Cat. p. 99 (1882). 
Synopsis of the Species.

Diameter of body 27 or 28 times in total length ; 228-250 folds. 1. multiplicata. Diameter of body 23 times in total length; 129 folds ........ 2. proxima. Diameter of body 37 or 38 times in total length; $180-190$ folds. 3. unicolor.

Diameter of body 47 to 53 times in total length;166-200 folds. 4. oligozona.

\section{Gymnopis multiplicata.}

Gymnopis multiplicata, Peters, Mon. Berl. Ac. 1874, p. 616, pl. i. fig. 1, and 1879, p. 939, pl. - . fig. 7; Bouleng. Cat. p. 100 (1882). Siphonops simus, Cope, Proc. Am. Philos. Soc. xvii. 1877, p. 91.

Dermophis ? simus, Peters, Mon. Berl. Ac. 1879, p. 938; Bouleng. l. c. p. 99.

Gymnopis sima, Cope, Proc. Am. Philos. Soc. xxii. 1885, p. 171. Costa Rica; Veragua; Antioquia.

\section{GyMnopis PRoxima.}

Siphonops proximus, Cope, Proc. Am. Philos. Soc. xvii. 1877 , p. 90. Dermophis ? proximus, Peters, Mon. Berl. Ac. 1879, p. 938 ; Bouleng. Cat. p. 99 (1882).

Gymnopis proxima, Cope, Proc. Am. Philos. Soc. xxii. 1885, p. 171.

Costa Rica.

*3. Granopis unicolor.

Rhinatrema unicolor, A. Dum. Mém. Soc. Cherb. ix. 1863, p. 321, pl. i. figs. 6,7 .

Gymnopis unicolor, Peters, Mon. Berl. Ac. 1879 , p. 939 ; Bouleng. Cat. p. 100 (1882).

Cayenne.

*4. Grinnopis oligozona.

Siphonops oligozonus, Cope, Proc. Am. Philos. Soc. xvii. 1877, p. 91.

Gymnopis ? oligozona, Peters, Mon. Berl. Ac. 1879, p. 939 ; Bouleng. Cat. p. 100 (1882).

Gymnopis oligozona, Cope, Proc. Am. Philos. Soc. xxii. 1885, p. 171 .

Guatemala ${ }^{1}$.

\section{Trphlonectes.}

Cacilia, part., Dum. \& Bibr. viii. p. 274 (1841); A. Dum. Mém. Soc. Cherb. ix. 1863, p. 311.

Typhlonectes, Peters, Mon. Berl. Ac. 1879, p. 940 ; Bouleng. Cat. p. 102 (1882).

Synopsis of the Species.

135-167 circular folds, interrupted on the back 99 circular folds, all complete

1. compressicauda. Circular folds indistinct

3. natans.

1 The origin of the type specimen is unknown. A specimen from Guatemala, received from the Basle Museum, is in the British Museum. 
*1. TrPhloneCtes COMPRESSiCAUdA.

Caccilia compressicauda, Dum. \& Bibr. viii. p. 278 (1841); Peters, Mon. Berl. Ac. 1874 , p. 45, and 1875, p. 483, pl. - .

Typhlonectes compressicauda, Peters, Mon. Berl. Ac. 1879, p. 941, pl. — ; Bouleng. Cat. p. 102 (1882).

Guianas; Venezuela ; N. Brazil ${ }^{1}$.

2. Typhlonectes KaUPiI.

Siphonops kaupii, Berthold, Götting. Nachr. 1859, p. 181, and 1867 , p. 361.

Cacilia dorsalis, Peters, Mon. Berl. Ac. 1877, p. 459, pl. - .

Typhlonectes dorsalis, Peters, Mon. Berl. Ac. 1879, p. 941; Bouleng. Cat. p. 103 (1882).

Typhlonectes kaupii, Bouleng. Ann. \& Mag. N. H. (6) viii. 1891, p. 457.

Venezuela.

*3. Typhloneutes natans.

Cacilia natans, Fischer, Mon. Berl. Ac. 1879, p. 941, and Arch. f. Nat. 1880 , p. 217 , pl. viii. figs. 5-7.

Typhlonectes natans, Peters, Mon. Berl. Ac. 1879, p. 941 ; Bouleng. Cat. p. 103, pl. ix. fig. 3 (1882).

Cacera, Colombia.

\section{Chthonerpeton.}

Chthonerpeton, Peters, Mon. Berl. Ac. 1879, p. 940 ; Bouleng. Cat. p. 104 (1882).

Synopsis of the Species.

Eyes distinct; diameter of body 26 times in total length;

78-100 circular folds.

Eyes indistinct; diameter of body 39 times in total length;

145 circular folds

1. indistinctum.

*1. Chthonerpeton indistinctum.

Siphonops indistinctus, Reinh. \& Lütk. Vid. Meddel. 1861, p. 203. Chthonerpeton indistinctum, Peters, Mon. Berl. Ac. 1879, p. 940 ; Bouleng. Cat. p. 104 (1882).

S. Brazil ; Buenos Ayres.

*2. Chthonerpeton pethrsil.

Chthonerpeton petersii, Bouleng. Cat. p. 104, pl. ix. fig. 2 (1882). Upper Amazon.

\section{SipHoNOPS.}

Siphonops, Wagl. Isis, 1828, p. 740, and Syst. Amph. p. 198 (1830); Peters, Mon. Berl. Ac. 1879, p. 940 ; Bouleng. Cat. p. 101 (1882).

Siphonops, part., Dum. \& Bibr. viii. p. 282 (1841); A. Dum. Mém. Soc. Cherb. ix. 1863, p. 317.

${ }^{1}$ A fine specimen from Manaos is in the British Museum. 
Synopsis of the Species.

Tentacle in front of and below the eye, which is perfectly distinct; diameter of body 20 to 25 times in total length; 85-95 circular folds, all complete

1. anmulatus.

Tentacle in front of and below the eye, which is perfectly distinct; diameter of body 32 times in total length ; 110-115 circular folds, all complete

\title{
2. paulensis.
}

Tentacle in front of and below the eye, which is very indistinct; diameter of body 46 times in total length; 133 circular folds, mostly interrupted on the dorsal and ventral lines

Tentacle in front of and close to the eye, and very slightly below it; eye more or less distinct; diameter of body 36 or 37 times in total length ; 100-104 circular folds, all complete.

\author{
3. brasiliensis.
}

4. hardyi.

\section{*1. Siphonops annulatus.}

Cacilia annulata, Mikan, Delect. Flor. Faun. Bras. p. - , pl. (1820) ; Spix, Serp. Bras. p. 74, pl. xxvi. fig. 1 (1824).

Siphonops annulatus, Wagl. Isis, 1828, p. 740, pl. x. figs. 1, 2 ; Dum. \& Bibr. viii. p. 282, pl. lxxxv. fig. 1 (1841); A. Dum. Mém. Soc. Cherb. ix. 1863 , p. 317 ; Peters, Mon. Berl. Ac. 1879 , p. 940 ; Bouleng. Cat. p. 102, pl. viii, fig. 4 (1882).

Siphonops interrupta, Gray, Cat. p. 59 (1850).

Guianas ; Brazil ; Ecuador; Peru.

*2. SiphoNops PAULENSIS.

Siphonops paulensis, Boettg. Kat. Batr. Senck. Ges. p. 62 (1892). S. Paulo, Brazil.

3. SIPHONOPS BRASILIENSIS.

Siphonops brasitiensis, Lütk. Vid. Meddel. 1851, p. 54 (1852); Reinh. \& Lütk. Vid. Meddel. 1861, p. 202 ; Bouleng. Ann. \& Mag. N. H. (6) viii. 1891 , p. 457.

Dermophis ? brasiliensis, Peters, Mon. Berl. Ac. 1879, p. 938 ; Bouleng. Cat. p. 99 (1882).

Brazil.

*4. Siphonops hardir. (Plate XXIV. fig. 3.)

Siphonops hardyi, Bouleng. Ann. \& Mag. N. H. (6) i. 1888, p. 189 , and viii. 1891 , p. 457 .

Porto Real, Prov. Rio Janeiro, Brazil.

\section{Bdellophis, g. $n$.}

Squamosals separated from the parietals. A single series of teeth in the lower jaw. Tentacle obtusely conical, exsertile, surrounded by a circular groove, in front of and below the eye, twice as distant from the nostril as from the eye. Body much flattened. No scales.

\section{*1. Bdellophis vimtatus, sp. n. (Plate XXIV. fig. 4.)}

Teeth very small. Snout depressed, rounded, strongly projecting; eye small, distinct, much lower down than the nostril. 125 circular 
folds, interrupted on the dorsal and ventral lines. Tail indistinct, rounded. Bright yellow, with a broad black dorsal band.

Total length 160 millim.; greatest diameter of body 6 millim.

A single specimen from Usambara, German East Africa; received from Dr. F. Werner.

\section{Gegenophis.}

Gegenes (non Hübn.), Günth. P. Z. S. 1875, p. 577.

Gegeneophis, Peters, Mon. Berl. Ac. 1879, p. 932 ; Bouleng. Cat. p. 101 (1882).

\section{*1. Gegenophis carnosus.}

Epicrium carnosum, Beddome, Madras Month. Journ. Med. Sc. 1870, p. 176.

Gegenes carnosus, Günth. P. Z. S. 1875, p. 577.

Gegenophis carnosus, Bouleng. Cat. p. 101, pl. viii. fig. 3 (1882), and Faun. Ind., Rept. p. 518 (1890).

Wynaad; Travancore ${ }^{1}$.

\section{SCOLECOMORPHUS.}

Scolecomorphus, Bouleng. Ann. \& Mag. N. H. (5) xi. 1883, p. 48.

*1. Scolecomorphus kirkiI. (Plate XXIII. fig. 3.)

Scolecomorphus kirkii, Bouleng. l. c.; Günth. P. Z. S. 1892, p. 555.

Nyassaland.

Table showing Geographical Distribution.

\begin{tabular}{|c|c|c|c|c|c|}
\hline & $\begin{array}{l}\text { West } \\
\text { Africa. }\end{array}$ & $\begin{array}{c}\text { East } \\
\text { Africa. }\end{array}$ & Seychelles. & S.E. Asia. & $\begin{array}{c}\text { Trop. } \\
\text { America. }\end{array}$ \\
\hline Ichthyophis ........ & & & & 2 & \\
\hline Dermophis ................ & 1 & 1 & $\ldots$ & $\cdots$ & 4 \\
\hline Нypogeophis $\ldots \ldots \ldots \ldots . . . .$. & $\ldots$ & 1 & 2 & & \\
\hline Cæcilia ....................... & $\cdots$ & $\cdots$ & $\cdots$ & $\cdots$ & 6 \\
\hline Rhinatrema ................ & $\dddot{1}$ & $\cdots$ & $\cdots$ & $\cdots$ & 2 \\
\hline Geotrypetes ............... & 1 & & & & \\
\hline 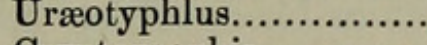 & 1 & $\cdots$ & $\because$ & 2 & \\
\hline Cryptopsophis ............. & 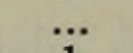 & $\cdots$ & 1 & & \\
\hline 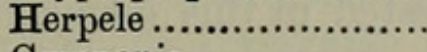 & 1 & $\cdots$ & $\cdots$ & $\cdots$ & 1 \\
\hline 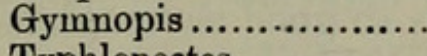 & $\cdots$ & $\cdots$ & 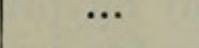 & 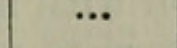 & 4 \\
\hline Typhlonectes................ & $\cdots$ & $\cdots$ & $\cdots$ & $\cdots$ & 3 \\
\hline Chthonerpeton ............. & $\cdots$ & $\cdots$ & $\cdots$ & $\cdots$ & 2 \\
\hline Siphonops ................... & $\cdots$ & 1 & $\cdots$ & $\cdots$ & 4 \\
\hline 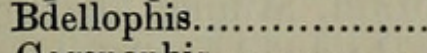 & $\cdots$ & 1 & & & \\
\hline Gegenophis .............. & $\ldots$ & $\because$ & $\cdots$ & 1 & \\
\hline Scolecomorphus $\quad . . \ldots \ldots . .$. & $\cdots$ & 1 & & & \\
\hline Total .... & 4 & 4 & 3 & 5 & 26 \\
\hline
\end{tabular}

1 A specimen from Kallar, Travancore, received from Mr. H. S. Ferguson, measures 280 millim.; diameter of body 9 millim.; 110 folds; uniform dark brown, somewhat paler beneath. 


\section{EXPLANATION OF THE PLATES.}

\section{Plate XXIII.}

Fig. 1. Cacilia buckleyi, Blgr., p. 407.

1a. ", " Side view of head, $\times 3$.

2. Rhinatrema bicolor, Blgr., p. 407.

. $a$. " " " Side view of head, $\times 2$.

$2 b . \quad " \quad$ " $\quad$ Lower view of anterior end.

2c. " " " ", posterior end.

3. Scolecomorphus kirkii, Blgr., p. 413. Upper view of anterior end.

$3 a$. " , " Side view of head, $\times 2$.

$3 b . \quad$ " $\quad$ " Lower view of anterior end.

3c. " " ",$\quad$ posterior end.

\section{Plate XXIV.}

Fig. 1. Geotrypetes petersii, Blgr., p. 408 . Upper view of anterior end.

1a. " " , Side view of head, $\times 2$.

$1 b . \quad " \quad, \quad$ Lower view of posterior end.

2. Cryptopsophis multiplicatus, Blgr., p. 409 . Upper view of anterior

$2 a$. " , $\quad$ Side view of head, $\times 2$.

$2 b$. " " " Lower view of posterior end.

3. Siphonops hardyi, Blgr., p. 412.

$3 a$. " , Side view of head, $\times 3$.

4. Bdellophis vittatus, Blgr., p. 412.

4a. " " Side view of head, $\times 2$.

2. On a new Species of the Genus Erinaceus from Somaliland. Вy Јонn Anderson, M.D., LL.D., F.R.S., F.Z.S., \&c.

[Received May 20, 1895.]

The Hedgehog, the subject of this description, is an adult female. It was living when presented to this Society on the 24th April, 1893, by Mr. H. W. Seton-Karr, F.Z.S., but died soon afterwards. When it was received at the Gardens it was regarded as an example of $E$. albiventris, Wagner ${ }^{1}$, a species which is distinguished from all other members of the genus by having only four digits on the hind foot. The Somali Hedgehog, however, has five welldeveloped toes.

Mr. Sclater, being aware that I was interested in this genus, in connection with my Egyptian researches, was so good as to entrust the specimen to me for description, now some time ago.

I may mention that $I$ have examined all the Hedgehogs preserved in the Museums of Paris, Frankfort on the Main, Munich, Berlin, and London ${ }^{2}$, and, owing the kindness of Mr. Ludwig Lorenz, have

1 Cf. Sclater, P. Z. S. 1893, p. 435.

2 I embrace this opportunity to express my indebtedness to Professor R. Hertwig, Munich ; Professor Dr. Boettger, Frankfort on the Main ; Professor Möbius and Mr. Paul Matschie, Berlin; Prof. A. Milne-Edwards, Paris ; and to Mr. Oldfield Thomas, for the facilities they have afforded me to study the specimens under their respective charges. 
had the opportunity of examining, in London, some of the specimens described by Fitzinger, preserved in the Vienna Museum.

After a careful consideration of all the materials which have come under my observation, I have arrived at the conclusion that this Hedgehog from Somaliland belongs to a species new to science. I have found, in the British Museum, the skin of the body (spines only) of a Hedgehog from Taf, in Central Somaliland, which seems to be identical with it. The registered number of this specimen is 85.12.10.2.

I propose to designate the new species $E$. sclateri.

It belongs to that section of the genus in which the pterygoid fossæ are well-developed, and in which the pterygoids do not contribute to the enlargement of the auditory chamber of the macerated skull. The following species, besides $E$. sclateri, fall under this division, viz., E. europaeus, Linn., E. concolor, Martin, E. algirus, Duv. \& Lereboullet, E. frontalis, Smith, E. auritus, Pallas, and those which are doubtfully distinct from the last, e.g., E. grayi, Bennett, E. megalotis, Blyth, and E. allulus, Stoliczka; and, finally, E. albiventris, Wagner, in which the hallux is absent, is also a member of this group. In the second section of the genus the pterygoid fossæ almost disappear, the pterygoids being enlarged and bullate, the cavity contributing to the enlargement of the auditory chamber of the prepared skull. The Hedgehogs which present this type of cranial structure are E. micropus, Blyth, E. pictus, Stoliczka, E. cethiopicus, Ehrenberg, and E. macracanthus, Blanford.

The Hedgehogs of the first section are referable to two subdivisions, depending on the nature of the post-glenoid process of the squamous. In one that process is solid and much smaller than the mastoid, whereas in the other it is as large as the mastoid process, and concave internally, but not bullate.

The following species, viz., E. europarus, $E$. concolor, E. algirus, $E$. frontalis, $E$. sclateri, and E. albiventris, fall under the first of these subdivisions, and $E$. auritus and its allies already mentioned under the second.

All Hedgehogs belonging to the first subdivision, and of which $E$. europceus may be regarded as the representative, have an area from the forehead to the nape devoid of spines. Their spines are perfectly smooth, that is they have no longitudinal ridges, and are circular in transverse section. They present, however, a finely striated appearance externally, due to the cells of their cuticular covering. In the Hedgehogs of the second subdivision there is no bare area on the mesial line of the head, and the spines are covered with longitudinal ridges bearing minute nodosities.

In the second great section of the genus with dilated pterygoids the post-glenoid process of the squamous becomes greatly enlarged antero-posteriorly, and hollowed out into a large bullate cavity continuous with the auditory chamber of the macerated skull. The Hedgehogs belonging to this type of skull, and of which $E$. cethiopicus may be regarded as the highest expression, have a bare area 
on the mesial line of the head and strongly ridged and nodose spines ${ }^{1}$.

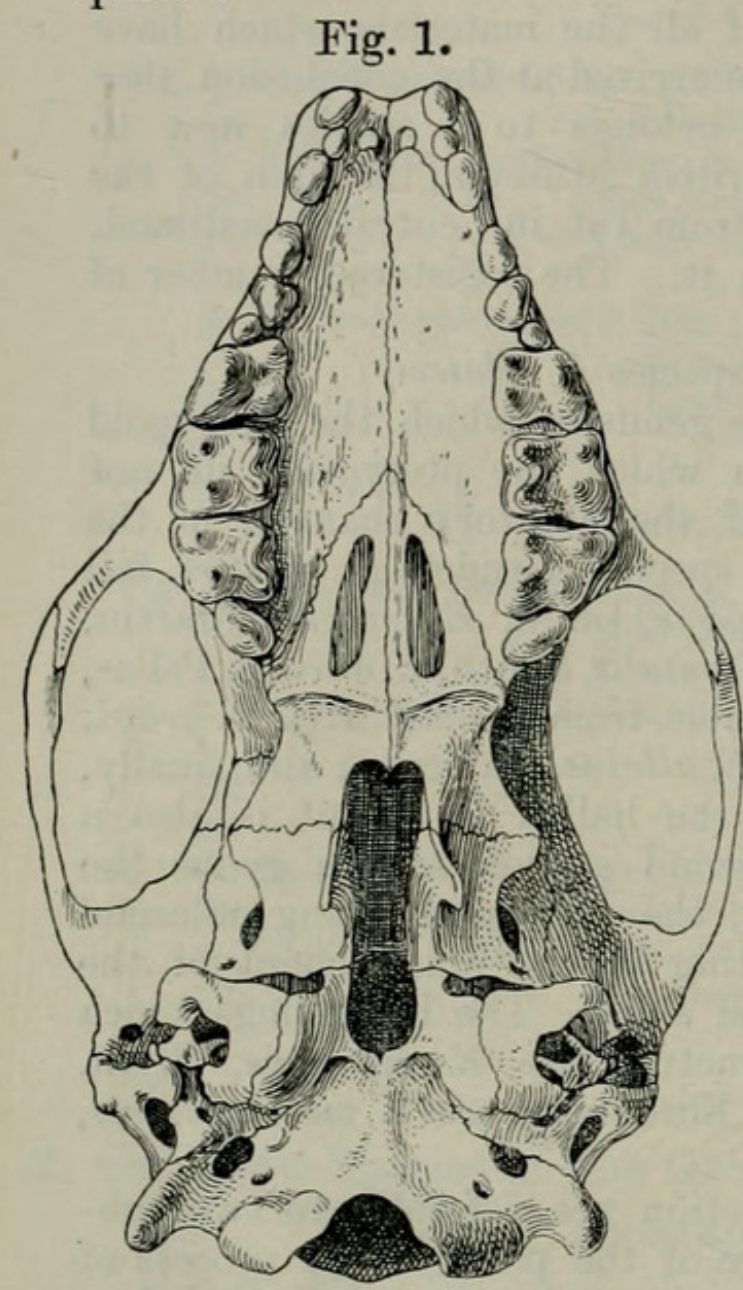

E. sclateri, And.
Fig. 2.

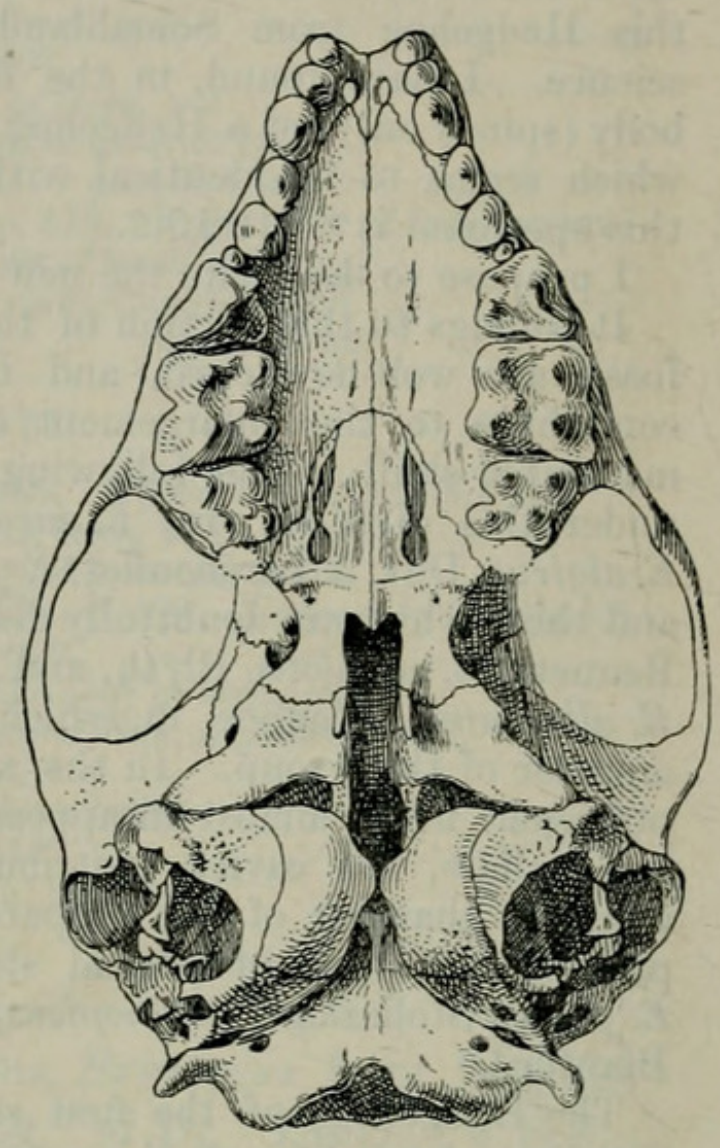

E. ethiopicus, Ehr.

It has been stated by Dobson, and repeated by others, that the spines of all the known species are marked by longitudinal ridges; but if the spines of $E$. europarus and its allies be subjected to microscopical examination in cross section, it will be found that they have a perfectly circular outline without any trace of longitudinal ridges, whereas if a spine of E. cethiopicus be treated in the same way the cross section is seen to be thrown into alternate risings and depressions, due to the presence of longitudinal ridges. The cavity of a spine of either of these groups in cross section consists of a number of inwardly projected septa enclosing chambers. In spines with ridges and furrows, the septa always correspond to the latter, i.e. they originate from the inner walls, whereas the ridges are outward bulgings of the chambers defined by the septa. The position of the latter (septa) is generally indicated externally by a dark longitudinal line, due to the greater thickness of the periphery of the spine opposite to a septum. It is the presence of these dark longitudinal lines that has doubtless given rise to the erroneous impression that they are ridges. The

${ }^{1}$ I give an enlarged view of the skull of $E$. sclateri and alongside of it one of $E$. athiopicus, to bring out the cranial features of the two groups. 
number of septa in the spines of a species is subject to considerable variation-in E. sclateri the lowest number being 21 and the highest 26 , but, among spines of 88 specimens of the genus, I have found the variation to be even greater than this.

The fur of this species has the coarse texture of $E$. europoeus, and distinctive of all the smooth-spined Hedgehogs, whereas in the ridged-spined forms the hair is soft and silky.

In E. sclateri, as in all the existing species of the genus, with the exception of $E$. europaeus and $E$. pictus, the third upper incisor has two roots. In the former it has always one, but in the latter the condition of the teeth varies, as in three out of four skulls the third upper incisor has only one root; but this is probably due to the union of two roots, or to incipient division, as the root in these teeth is marked by a longitudinal furrow on each side. In the fourth skull the tooth has two distinct roots.

This species (E. sclateri) has a double-rooted canine, which is the general character of this tooth throughout the genus. In $E$. europceus, however, the canine has usually only one root; but there are exceptions, as in five out of fifteen individuals observed by me it has two roots, while in the widely different $E$. pictus one out of four specimens examined has the tooth with only one root. The instability of the rooting of this tooth is further evinced by a skull of E. europacus in which the canine has a single root on one, and two roots on the opposite side. In E. concolor, which is very closely allied to $E$. europaeus, the canine has two roots, as in E. algirus.

In E. sclateri the first upper premolar, as in E. algirus, E. frontalis, E. albiventris, E. cethiopicus, and E. macracanthus, has two roots ; whereas in E. europaeus, E. concolor, E. pictus, and E. micropus it has usually one root. On the other hand, in the forms that can be grouped with $E$. auritus, such as $E$. megalotis and $E$. grayi, the first upper premolar may have either one or two roots.

The second upper premolar of E. sclateri has three roots, which is the general character of this tooth throughout the genus, with the exception of those species in which it is very feebly developed and occasionally shed even before the other teeth become worn, and in which it has only a single root. These species are $E$. micropus, $E$. pictus, and also E. cethiopicus; but in the last I have met with an example with a double-rooted second upper premolar. Among the species in which it generally has three roots exceptions also occur, as Dr. Scully has recorded an instance (E. megalotis) in which only two roots are present, and I have observed three similar cases in E. grayi, a species which with E. megalotis may: possibly, be ultimately regarded as only varieties or local races of $E$. auritus an opinion which has already been expressed by Dobson.

The following are the external characters of this species :-

Snout short; ears broadly rounded, but not so high as the interaural spines. Feet well developed; pollex twice as large as the hallux. Two large pads below the wrist, placed side by side, the external pad the larger. The fifth toe twice as large as the hallux;

Proc. Zool. Soc.-1895, No. XXVII. 
a large lingulate pad on the middle of the plantar surface, which is sparsely covered with hair from the heel to the pad. Claws moderately long. Tail short, about half the length of the hind feet. Spines finely striated, the longest about 18 millim. in length and 1 millim. in diameter. The inter-aural spines are not quite so long as the longest body-spines.

The apices of the spines are generally yellowish white, passing into a narrow orange-yellow band, which merges into a brown band followed by a broad yellowish or white band, the basal ends of the spines being dusky.

The face anterior to the eyes, and the chin, are nearly nude, the skin of these parts having a livid hue and sparsely covered with minute dusky hairs, those along the margin of lips being whitish. The ears also are nearly nude, of a livid hue, and are only sparsely clad with short hairs. The fore and hind limbs are thinly clothed with brownish and yellowish hairs. The lower part of the belly and the area behind it are covered with brownish fur. The head behind the livid snout and chin, the sides of the body below the spines, the throat, chest, and upper part of the abdomen are all yellowish white.

\begin{tabular}{|c|c|}
\hline to $v$ & \\
\hline tail & $14 \cdot 5$ \\
\hline to snout. & $41 \cdot 0$ \\
\hline 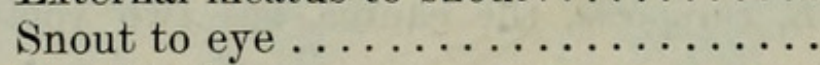 & $21 \cdot 5$ \\
\hline Hei & $24 \cdot 0$ \\
\hline Length of & $18 \cdot 0$ \\
\hline , & $28 \cdot 5$ \\
\hline " of pollex & $\begin{array}{l}2 \cdot 5 \\
1 \cdot 6\end{array}$ \\
\hline
\end{tabular}

The skull of E. sclateri is much smaller than that of $E$. frontalis, Smith, the only species, next to $E$. algirus, with which it can be compared, but it is more closely allied to the former than to the latter. The difference in size between the skull of the British Museum specimen of $E$. frontalis, Smith (E. diadematus, Dobson, but not of Fitzinger), which is a male, and that of $E$. sclateri, which is a female, is greater than mere sexual dissimilarity would account for. It should be viewed in connection with the differences that exist between the two animals when their external characters are studied, and which are such that I have had no course left me but to regard them as specifically distinct.

In $E$. frontalis the spines between the ears instead of being rather shorter than the body-spines, as in E. sclateri, are decidedly longer and form an eminence between the ears. It has only a single large pad below the wrist, whilst in E. sclateri there are two placed side by side. The hind foot of $E$. frontalis has an acutely pointed, well-developed, nipple-like tubercle, opposite to the hallux, whereas in E. sclateri there is a broadish flat lingulate pad in a similar position. The ears also of $E$. frontalis are 
not so rounded as those of $E$. sclateri. The longer spines of $E$. frontalis have exceedingly narrow yellowish tips, with a very broad dark brown band below them, so that the animal has a dark colour, almost like E. collaris of India; whereas in E. sclateri the spines are broadly tipped with white succeeded by a brown band, but not so broad or dark as in E. frontalis, so that the coloration of this Hedgehog is nearly white, but with an orange-brown tint. In $E$. frontalis the face from behind the angle of the mouth, through the eye, and between the eyes to the nose is russetbrown. The shoulder, fore limbs, a band across the chest, the body, and hind limbs are dark russet-brown; the remaining parts, viz., the forehead, the front of the ears, the side of the neck, and the chest behind the brown pectoral band, are white. By these differences in coloration the two species are at once distinguished from one another, while their specific distinctness is established by the other structural dissimilarities already enumerated.

This species is only known from Somaliland.

This genus is represented in Africa by six species, viz., E. algirus, Duv. \& Lereboullet, E. frontalis, A. Smith, E. sclateri, E. albiventris, Wagner, E. athiopicus, Ehr., and E. auritus, Gmelin; and the following is their synonymy and distribution:-

\section{Erinaceus algirus, Duv. \& Lereb.}

Erinaceus algirus, Duv. \& Lereboullet, Mém. de la Soc. du Mus. d'Hist. Nat. de Strasbourg, iii. (1840) pp. 4-5; Dobson, Monogr. Insect. pt. i., Jan. 1882, p. 12 (external characters only); Lataste (F.), Act. Soc. Bordeaux, xxxix. (1885) p. 200 ; Explor. Sc. de la Tunisie, Cat. Crit. des Mammif. 1887, p. 5, et Suppl. pp. 39-41.

Erinaceus krugi, Peters, SB. Ges. naturf. Fr. Berlin, 1877, p. 78 ; Dobson, op. cit. pp. 11, 12.

Erinaceus fallax, Dobson, op. cit. pp. 9, 10.

Erinaceus deserti, Dobson, op. cit. pp. 12, 13 (cranium).

Distribution. Tripoli, Tunisia, Algeria, and Marocco (Tetuan).

\section{Erinaceus frontalis, A. Smith.}

Erinaceus capensis, Andrew Smith, Phil. Mag. \& Annals of Phil. vol. ix. Jan.-June 1831, pp. 61, 62 (nomen nudum).

Erinaceus frontalis, Andrew Smith, South Afr. Quart. Journ. vol. i. (1830) no. 5 , Oct. 1831 , p. 10 ; ibid. vol. ii. Dec. 1833 , p. 61 ; Ill. of South African Zoology, 1849, plate iii. ( $q$ ); Bennett, Proc. Zool. Soc. ii. (1832) p. 193 ; Wagner, Säugeth. Suppl. vol. ii. (1841) p. 21 ; Fitzinger, SB. Ak. Wien, lvi. 1867, p. 854.

Erinaceus capensis, Smith, T. Smuts, Diss. Zool. Enum. Mamm. Cap. 1832 , p. 8.

Erinaceus diadematus, Dobson, op. cit. p. 10 (nec E. diadematus, Württemb., Fitz.).

Distribution. South-western Africa, Benguella to the Cape of Good Hope. 
3. Erinaceus sclateri, $\mathrm{n}$. $\mathrm{sp}$.

Distribution. Somaliland.

4. Erinaceus albiventris, Wagner.

Erinaceus albiventris, Wagner, Säugeth. Suppl. vol. ii. 1841, p. 22 ; Dobson, op. cit. p. 11.

Erinaceus pruneri, Wagner, Säugeth. Suppl. vol. ii. 1841, p. 23. Peroëchinus pruneri, Fitz. SB. Ak. Wien, t. lvi. 1867, p. 856.

Peroechinus albiventris, Fitz. SB. Ak. Wien, t. lvi. 1867, p. 857.

Erinaceus heterodactylus, Sundevall, Vetensk.-Akad. Handl. (1841), Stockholm, 1842, p. 227.

Erinaceus diadematus, Prinz Paul, Rüppell, Mus. Senck. t. iii. (1845) p. 159 (nomen nudum); Fitz. SB. Ak. Wien, t. lvi. 1867, p. 853.

Erinaceus adansoni, de Rochebrune, Bull. Soc. Philom. Paris, (7) t. vii. 1883 , p. 7 .

Distribution. Senegambia across Central Africa, southwards to Ukamba and northwards to Somaliland.

This species has been obtained in the following localities:Senegal ; Saint Louis; Cape Verd; Joal; MacCarthy's Island, River Gambia; Accra, Fantee; Porto Seguro, Togo; Gaboon; Kitui, Ukamba; Tabora; Kasé ; Kilima Njaro ; Wakilomi, District of Maka; Central Somaliland; Sennaar; Kordofan; and region of Upper Nile.

5. Erinaceus athiopicus, Ehrenberg.

Erinaceus athiopicus, Ehr. Symbolæ Phys. Decas ii. 1832.

Erinaceus auritus, Rüppell (non S. G. Gmelin), Neue Wirbelth. 1835 , p. 40 , in part; Tristram, Survey of West Palestine, 1884, p. 24 .

Erinaceus senaarensis, Hedg. Isis, 1839 , p. 5.

Erinaceus brachydactylus, Wagner, Säugeth. Suppl. ii. 1841, p. 24.

Hemiechinus pallidus, Fitzinger, SB. Ak. Wien, 1867, p. 866.

Erinaceus platyotis, Dobson (nec Sundevall), op. cit. p. 12.

Erinaceus deserti, Loche, Cat. Mammif., \&c., de l'Algérie, 1858, p. 20 ; Dobson, op. cit. pp. 12, 13 (nec cranium); Lataste, Act. Soc. Bordeaux, xxxix. 1885, p. 202 ; Explor. Sc. de la Tunisie, Cat. Crit. des Mammif. 1887, p. 5, et Suppl. pp. 39-41.

Erinaceus algirus, Dobson, op. cit. p. 12 (cranium).

Distribution. Upper Nile Valley, Sennaar to Abyssinia, the Red Sea littoral (Suakin), and northwards to Nubia (Dongola).

6. Erinaceus auritus, S. G. Gmelin.

Erinaceus auritus, S. G. Gmelin, Nov. Comment. Petrop. xiv. 1770 , p. 519 , tab. xvi.; Pallas, ibid. p. 573, tab. xxi. fig. 4 ; Geoffroy St.-Hilaire \& Audouin, Descr. de l'Egypte, Hist. Nat. ii. (1827) pp. 737-739, pl. 5. fig. 3; Audouin, ibid. pp. 745, 746, Suppl. pl. i. (skull and teeth); Dobson, Monogr. p. 16. 
Erinaceus libycus, Hempr. \& Ehr. Symb. Phys. Decas ii. 1832; Dobson, Monogr. p. 16 (nec syn.).

Erinaceus hypomelas, Brandt ${ }^{1}$, Bull. Ac. St. Pétersb. 1836, p. 32. Erinaceus platyotis, Sundevall ${ }^{2}$, Vet.-Ak. Handl. Stockholm, (1841) 1842, p. 232.

Erinaceus aegyptius, Geoffroy ${ }^{3}$, Rüppell, Mus. Senck. iii. 1845, p. 159.

Erinaceus frontalis, Dobson (nec E. frontalis, A. Smith), Monogr.

p. 18.

Erinaceus brachydactylus, Tristram (not Wagner), Survey of Western Palestine, 1884, p. 25; Hart, Fauna \& Flora of Sinai Petra, \&c. 1891 , p. 238 , pl. i. fig. 2.

Distribution. Lower Egypt; Sinaitic Peninsula; Palestine; Cyprus ; Turkey in Asia to Kirghis Steppes.

In Africa it is confined to Lower Egypt.

\section{Note on the Structure and Habits of the Sea-Otter}

\section{(Latax lutris). By R. LydeKKer.}

[Received April 9, 1895.]

Through the kindness of Mr. J. Cole Hartland, of Yokohama, I have received the following notes on the structure and habits of the Sea-Otter made by Mr. H. J. Snow, who for the last twenty years has been engaged in hunting these animals and fur-seals in the Kurile Islands. As they somewhat revolutionize the current ideas as to the position of the hind limbs, I think they are decidedly worth laying before the Society.

Commenting on a reproduction of Wood's well-known figure given on page 98 of the second volume of 'The Royal Natural History,' Mr. Hartland writes me that "The fore limbs are much shorter than represented, and when on shore the chest, as far as the end of the breast-bone, has the appearance of almost touching the ground. The abdomen is raised considerably from the ground and the hind flippers are doubled back, the Sea-Otter being incapable of placing its hind flippers in the position represented in the drawing. It occurred to Mr. Snow that the illustration may have been taken from a specimen shot by himself and set up by Ward of Rochester, New York, photos of which I enclose. The attitude of this specimen is quite misleading, and not at all that assumed by the animal when on shore. Mr. Snow has had several opportunities of getting good observations of these animals when on shore-on one occasion he saw some 20 or more on a rocky point

1 Prof. Büchner has been so good as to inform me that the spines on the head of the type are not divided into two lateral groups by an area destitute of spines, and that the spines are distributed quite as in $E$. auritus.

${ }^{2}$ I am indebted to Prof. F. A Smith, of Stockholm, for the information that in the type there is no bare area on the mesial line of the head, and also for the opportunity to examine some of the spines of Sundevall's specimen.

3 This name is taken from the unpublished Catalogue of Mammals in the Paris Museum, by (Étienne) Geoffroy St.-Hilaire. 
of one of the Kurile Islands, and succeeded in killing 9 of them. Their mode of locomotion is by a series of short springs from the hind flipper-he never saw them wall in ordinary acceptance of the term, i. e. by moving the limbs alternately. With regard to the tail-it is not cylindrical but flattish, being more than twice as broad as it is thick. It only tapers to a very slight extent, except at the extreme end, where it runs off sharply to a bluntish point.

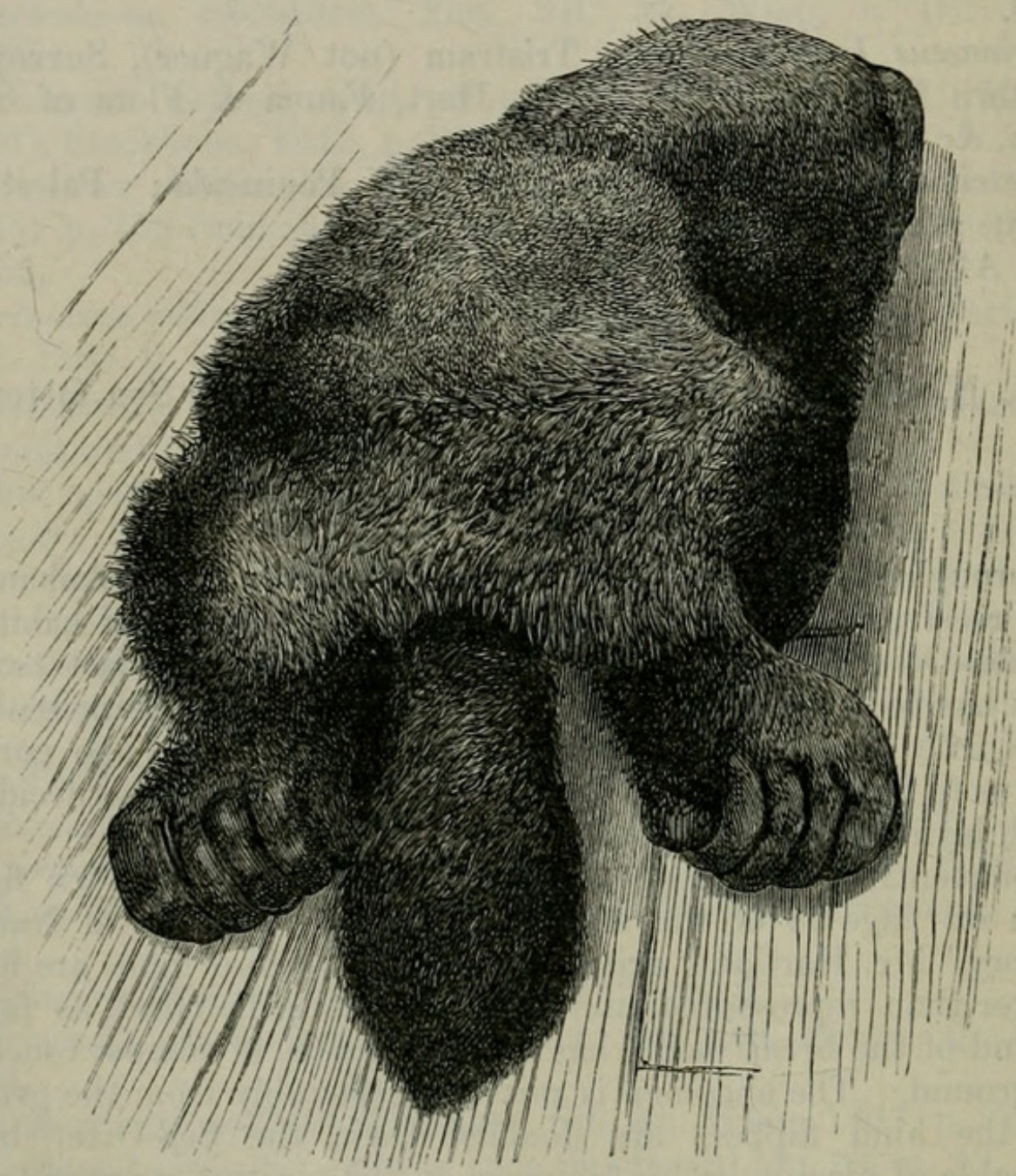

Latax lutris.

Dead Sea-Otter lying on deck; it exhibits the short tail, and the hind paws turned backwards, in the manner said to be natural to the animal when walking.

The whiskers are not so bushy and thick as represented in the drawing. They resemble the whiskers of the Cat, but are coarser. The cry of the Sea-Otter resembles the 'meaow' of a Cat; that of the young is almost identical, but in the adult it is somewhat deeper.

"Habitat. The southern limits of the animal extend as far as Southern California and Mexico. On the Asiatic side, it occurs at the Komandorski Islands, Kamschatka, and the Kurile Islands.

"Breeding. As a rule but one is produced at birth, but occasionally two. Mr. Snow has seen two small pups with their mother, 
UHAL MIS 


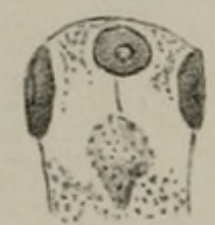

1
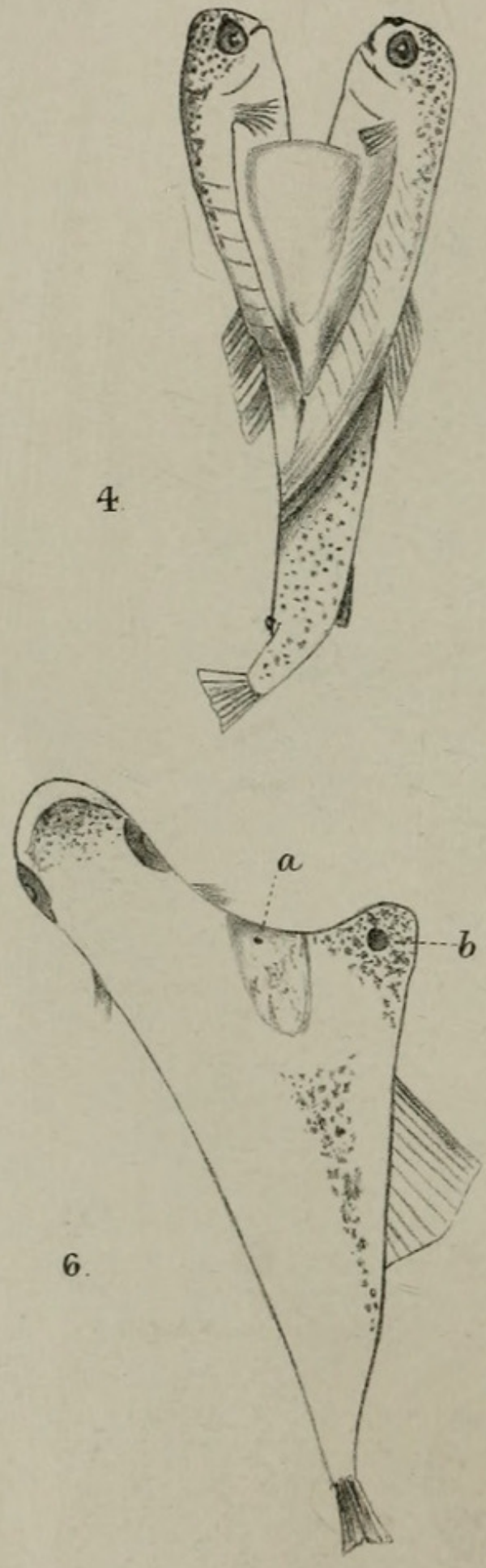

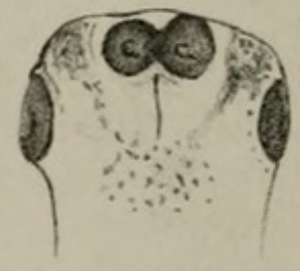

2.
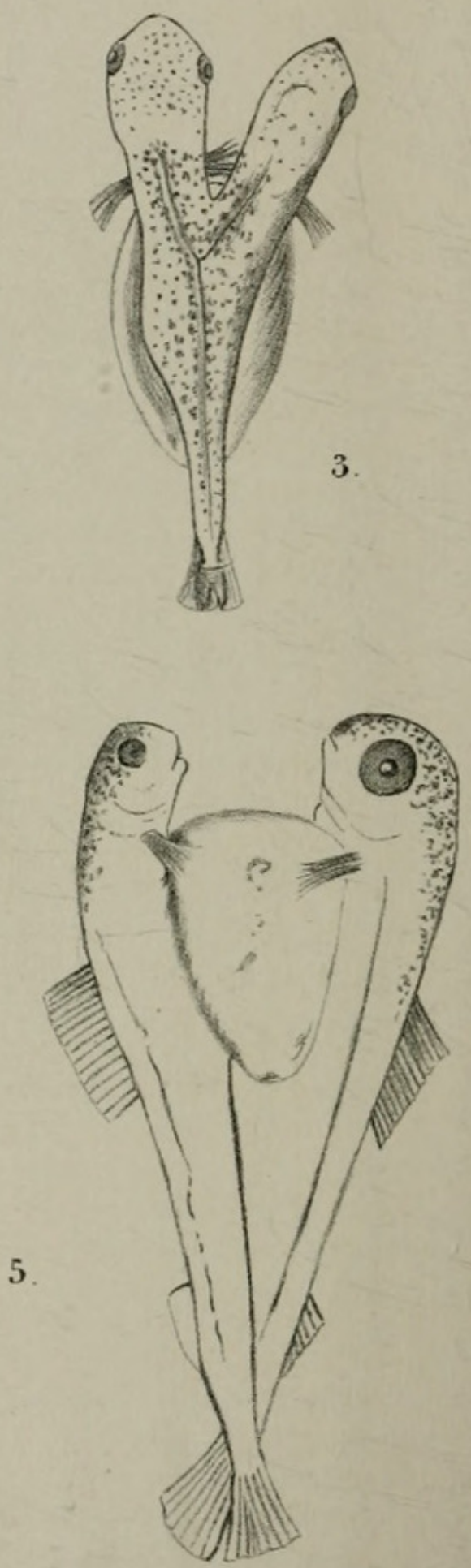
and has taken two from the inside of an Otter he killed. It is not absolutely known at what age the Otter arrives at maturity; Mr. Snow believes that they do so in the third year.

"Habits. Crabs and sea-urchins are the usual contents of the stomach, but occasionally small fish and spawn are also found. The crabs are crushed by the strong molar teeth; it being impossible that the crushing is produced by the striking of two shells together in the manner described by Elliot, as the form of the fore feet will not allow of anything being grasped. The Otter dives for its food and returns to the surface with the prey held between its two fore paws, in which it continues to hold it while eating it. On many occasions Mr. Snow has seen schools of from 10 to 50 or more Otters together some 10 or 15 miles from any land, but not of late years.

" Hunting. The mode adopted by Europeans is to 'run' the Sea-Otter with three boats, each manned by 4 or 5 men, a hunter being in the bow armed with a rifle. When an Otter is 'raised' (as it is called) the boats proceed to surround it, lying some 500 to 600 yards apart in the form of a triangle. The boats are so manœurred that the otter is kept between them. Every time the animal makes its appearance above water, it is shot at, until it is secured. When the Sea-Otter is netted, as described on page 101 of the volume eited, it becomes entangled in the meshes and drowned. The long white hairs of the fur, which are not removed in dressing, form its chief beauty."

Apart from the interesting account of the creature's habits, the especial importance of these notes is in regard to the doubling back of the hind feet, and the jumping motion in walking; in both of which respects the Sea-Otter appears to resemble the true Seals. I regret my correspondent has not sent me a photograph of the living animal; but the accompanying reproduction of a photograph of a recently killed specimen, as it lay on deck (p. 422), gives a good idea of the form of the hind feet and tail.

\section{On Double Malformations amongst Fishes. By Bertram C. A. Windle, D.Sc., M.D., M.A., Professor of Anatomy in Mason College, Birmingham.}

[Received May 10, 1895.]

\section{(Plate XXV.)}

\section{Introduction.}

The following observations are based upon the examination of about fifty trout-embryos presenting some grade, more or less advanced, of double monstrosity, and upon the descriptions of similar or allied forms to be met with in the literature of the subject, which I have endeavoured to examine as exhaustively as possible. As I shall have to allude to most of these papers in a later part of this communication, I shall here content myself with 
making mention of a few of the earlier notices on the point, to which I shall not again have occasion to revert. As far as I know the earliest description of a double fish is that given by Aldrovandus (1):- "captus fuit," he says, " in Nilo Egypti fluvio, non procul ab oppido Latislana cognominato. Hic piscis magnitudinem fere Crocodili adæquabat, coloris erat leucophæi albicantibus maculis insigniti. Habebat quidem duo capita etc." This description, which seems to be original to Aldrovandus, since I have been unable to find it in any of the other similar works which I have searched, must have been based upon the description of some double fish, perbaps a Shark, like that in the R. C. S. Museum. It must also have been enormously exaggerated, since there is no other description of a fish having lived to attain any but a small size. According to von Baer (2), Jussieu, in 1754 (3), exhibited to the French Academy two small fishes united by their bellies. In 1765 , Jacobi (4) gave the first account of any importance of the double forms which he had observed in a fish-hatching establishment:- " En faisant éclore des truites," he says, "j'ai quelquefois remarqué quantité d'avortons ou de monstres, certaines années plus, d'autres moins. Quelques-uns avaient deux têtes et le corps bien formé ; d'autres avaient le ventre commun et du reste étaient deux poissons bien distincts comme seraient deux poissons ordinaires que l'on coucherait sur une table bien serrés l'un contre l'autre par le ventre." According to von Baer, Rudolphi (5), Heusner (6), and Rathke (7) have mentioned similar forms, but I have been unable to refer to the original papers.

\section{Observed forms of Duplicity.}

1. Three eyes of same size (Plate XXV. fig. 1). I have three specimens in which the head is somewhat broader than usual, and is provided with a third, median eye, which appears from external examination to be of the same size as those to each side of it. I have not found this condition, which seems to be the least manifestation of duplicity, mentioned in any of the papers to which I have referred.

2. Three eyes, the median being larger than either of the lateral. I have one specimen of this class. I have not examined the median eye by sectional method, but from its external appearance it appears to be composed of two eyes fused together.

3. Four equal-sized eyes. I have one specimen of this condition myself (fig. 2), and it has also been described by Knoch (8) and by Klaussner (9). In the instance given by the last-mentioned writer, the fish had two distinct heads, one of which was provided with two, the other with four eyes, the condition thus being one of triplicity. Knoch states that there may be two mouths in cases of the kind included in this class. Such is not the case in my specimen.

4. Two heads, the duplicity extending as far back as the otic region. None of my specimens fall into this class, instances of 
which have been described by Knoch, von Baer, Klaussner, St.Hilaire (10), and Lereboullet (11).

5. Duplicity extending to the region of the pectoral fins (fig. 3). I have several instances of this condition, which has also been described by von Baer and Rauber (12). In these cases, as can be seen when the yolk-sac is still present in the specimen, the division extends as far back as the anterior border of that appendage. I may here mention, as some stress has been laid upon that point by de Quatrefages (13), that, although I have carefully looked for it, I have never found any sign of a notch or fissure at the anterior border of the yolk-sac in these or any other of my specimens, such as he saw in some of his and believed to be an indication of the union of two originally distinct sacs.

6. Duplicity extends to the posterior border of the yolk-sac, the caudal extremity of the fishes being quite single (fig. 4).

7. Duplicity extends a short distance behind the posterior border of the yolk-sac, so that there is a triangular gap between the sac and the adjacent sides of the two bodies. The caudal extremity is, however, quite single. I have several specimens of each of the conditions described in this and the preceding class.

8. Duplicity extends to the posterior border of the yolk-sac. Behind this there are two caudal extremities overlapping one the other and firmly united by their contiguous aspects. Each is provided with a distinct and independent caudal fin, a point easily overlooked in a cursory examination, since one overlies the other (fig. 5). In these cases there are two vertebral columns; and from the relation of the caudal ends to one another, it would appear that at some period of development they had been separate, and had subsequently fused in part with one another. I have several specimens belonging to this class, and the condition has also been described and figured by Rauber.

9. Union by the caudal extremities alone. I have not seen this condition, which has been noted by Klaussner, Lereboullet, and Rauber.

10. Union is by the ventral aspects at the site of attachment of the yolk-sac (anakatadidymus). I have specimens of this class, which has also been described by de Quatrefages and Valentin (14).

In the above-mentioned cases the two portions, greater or smaller, of which the double monster consisted are of approximately the same size. As a matter of fact, the occurrence of two united fishes, each being of exactly the same size, must be an occurrence of some rarity. I find it in none of my specimens, and in by far the greater number of recorded cases the inferiority in size of one member is especially mentioned. There is, however, no such marked difference in size as is met with in another group, which should now be considered, that, namely, of

11. Parasites, as they may be called, adopting a term familiar to teratologists. In these cases one member is reduced to the condition of a mere appendage to the larger and more perfect half. A few instances of this condition may be briefly described from 
amongst those in my collection ( $a$, fig. 6 ). On the left side of the right fish, which is itself well-formed and normal in every way, and at about the site of the pectoral fins, there is a pointed projection, representing a second embryo. This projection is unprovided with branchia and has no mouth, but on its under surface there is a single median round patch of pigment, which, from its identity of appearance with certain other conditions yet to be mentioned, I take to be an ill-developed eye. (b) In this ease the second fish, though much smaller than its normal fellow, is recognizable as a fish. It possesses a mouth and a normally formed right eye, that of the left side being represented by a circular patch of pigment like that alluded to in the first case. (c) In this case the head of the parasite has a mouth and is of a shape approximating to the normal, but possesses no eyes nor even pigment patches to represent them.

Lereboullet mentions an interesting case (series ii. no. 19), in which he was able to observe two stages in the development of a parasite. He says, "Je mis à part un œuf (de brochet) âgé de cinq jours, offrant une large bandelette embryonnaire normale avec son sillon; mais sur le côté droit de cette bandelette et tout près de sa base, on voyait se détacher du bourrelet blastodermique un très-petit tubercule, de forme triangulaire. La présence de ce germe accessoire partant du bourrelet blastodermique m'annonçait la production d'un embryon double, ou plutôt en raison de la petitesse du tubercule, un embryon muni d'une languette analogue à celles que j’avais vues précédemment. Cependant je ne revis cet œuf que huit jours plus tard. Le Poisson âgé de treize jours était éclos et très-agile. Il paraissait simple et régulièrement conformé; mais en l'examinant avec attention, je vis qu'il existait, au niveau de la nageoire pectorale du côté droit, un tubercule à peine sensible." From this observation it would appear that minor evidences of duplicity may be of more frequent occurrence than would be supposed, but so slight in their nature as to be easily overlooked.

Before leaving the subject of the various classes into which these double forms can be divided it may be well to note ,two points. In the first place, it should be observed that as yet no such form as that known to teratologists as katadidymus-a form, that is, in which two bodies are connected with a single cephalic extremity-has ever been described: a somewhat remarkable fact. And, lastly, mention should be made of a singular and most anomalous form described by Klaussner, in which two embryos quite divided from one another lay upon the same yolk-sac side by side, but with the cephalic end of one by the caudal end of the other. I have not seen or found in any of the papers to which I have referred any parallel to this case, which is difficult to account for by any of the theories of duplicity now holding the field.

\section{General Observations.}

1. Relative positions of the two members. The commonest position, as has been pointed out by Knoch, is side by side, but 
this is because it is more common for the point of union to lie in front of the anterior limit of the yolk-sac than behind that appendage. When the separation between the two fishes extends further back, some form or another of torsion occurs, due to the gradual shrinkage of the sac, by which the relations between the two fishes are altered. Thus, if the separation extends to the posterior border of the sac only, the caudal end of the monster being single, that part will lie with its dorsal and ventral surfaces upwards and downwards, whilst the anterior parts will lie on their sides with their ventral aspects drawn towards one another by the contraction of the yolk-sac (see fig. 4). If, again, the separation is complete between the two fishes, the condition being that of anakatadidymus, both fishes will finally lie venter to venter in their entire length. Finally, where the separation of the caudal ends has been only temporary, as in the forms included in class 8 , the cephalic ends, which are separate from one another, will lie with their ventral surfaces opposed, whilst the caudal ends are thrown one over the other and united in that position. From an examination of the numerous cases figured and described at all ages, it would appear that the embryos always at their earliest period of development lie side by side and that the subsequent changes in position of a part or the whole extent of their bodies are due to the influence of the contraction of the yolk-sac as it gradually becomes emptied of its contents.

2. Imperfections in one or both members of the double monstrosity. It has been already mentioned that in cases of parasitism the appendage is often very imperfectly developed, especially in connection with its mouth and eyes, and the same is true even in those instances in which there is no very remarkable difference in size between the two members. The following table of instances examined by myself will show this point quite clearly so far as regards the eyes :-

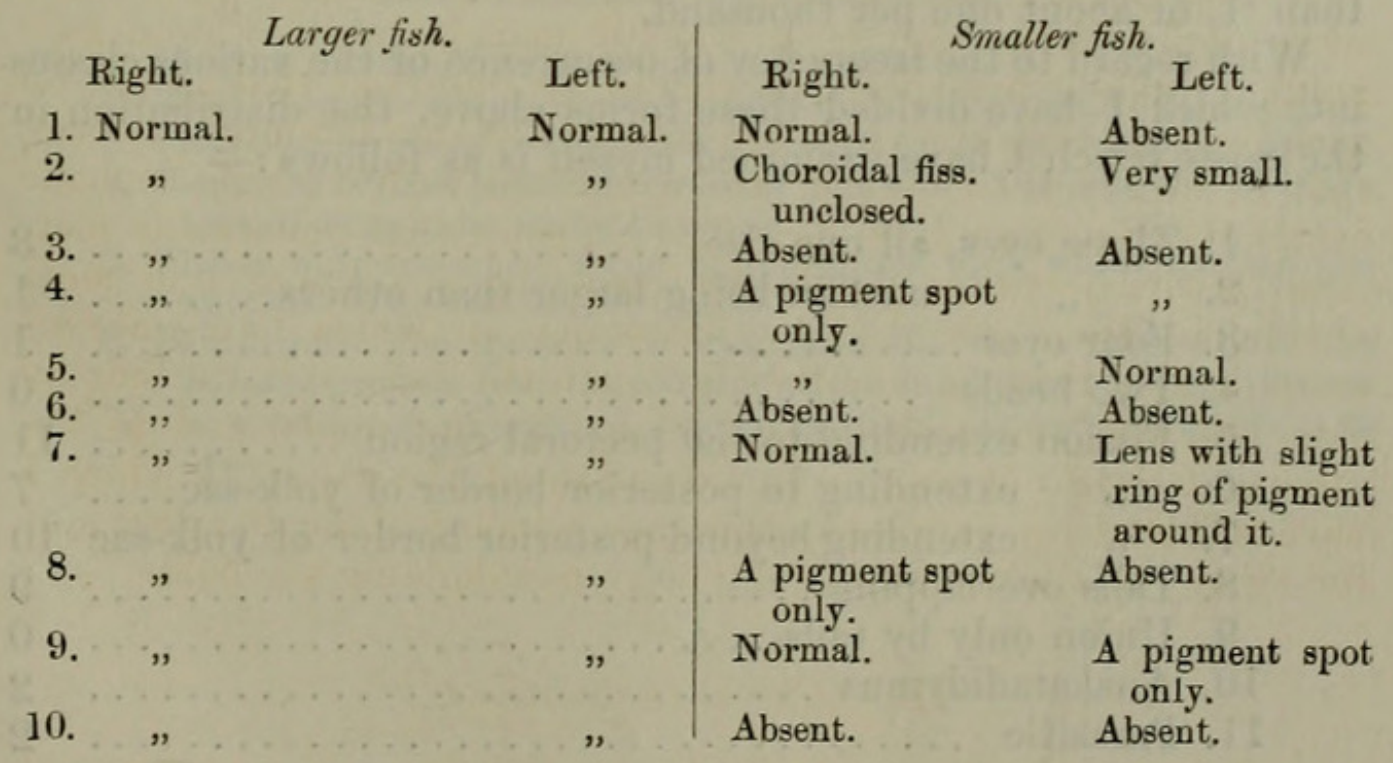

In several instances also there is a considerable degree of mal- 
formation of the jaws, as in the following cases:-(a) In this case the smaller head was unprovided with eyes and the lower jaw was very short and tapered rapidly to a sharp point. (b) In this case the upper jaw was much shorter than the lower, which projected a long way in front of it: there was, in fact, an almost complete failure to develop of that portion of the head which is placed in front of the eyes. (c) In this case the condition was carried still further, for so extensive was the arrest of the development of the anterior part of the skull that the two eyes were placed quite close to one another, with scarcely any separation between them. These two last forms approximate to the condition known as cyclopia.

3. Frequency of occurrence. Jacobi, as has already been mentioned, stated that double monstrosities occurred more frequently in some years than in others ; and I remember the late Mr. Burgess, the founder of the fish-hatching establishment at Malvern, making exactly the same remark to me, though he was unable to assign any cause for the variation. They have been met with amongst Sharks, Mackerel (15), Salmon, Trout, Perch, and Pike. I do not know whether any statisties have been drawn up at any of the fishhatching establishments as to the percentage of double monsters to normal forms, but the following figures have been obtained from data in some of the papers to which I have referred:-

$\begin{array}{clcc}\text { Observer. } & \text { Fish. } & \text { No. Examined. } & \text { No. of Double monsters. } \\ \text { Rauber. } & \text { Trout. } & 1000 & 2 \\ & \text { Pike. } & 325 & 1 \\ \text { Coste (16). } & \text { Various. } & 400,000 & \text { Orer } 100 \\ \text { Lereboullet. } & \text { Pike. } & 203,962 & 222\end{array}$

From the last figures, which are the most complete, it would appear that the percentage of occurrence in the pike is rather less than $\cdot 1$, or about one per thousand.

With regard to the frequency of occurrence of the various classes into which I have divided these forms above, the distribution in the cases which I have examined myself is as follows:-

1. Three eyes, all one size $\ldots \ldots \ldots \ldots \ldots \ldots \ldots \ldots$. 3

2. " median being larger than others........ 1

3. Four eyes ......................... 1

4. Two heads $\ldots \ldots \ldots \ldots \ldots \ldots \ldots \ldots \ldots \ldots \ldots$. 0

5. Fission extending to the pectoral region $\ldots \ldots \ldots \ldots 11$

6. " extending to posterior border of yolk-sac.... 7

7 . $"$ extending beyond posterior border of yolk-sac 10

8. Tails overlapping ........................ 9

9. Union only by tails $\ldots \ldots \ldots \ldots \ldots \ldots \ldots \ldots \ldots, 0$

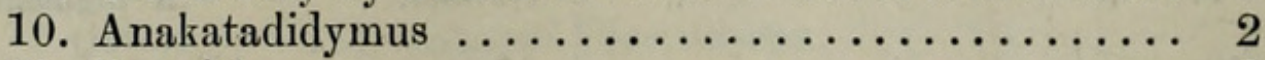

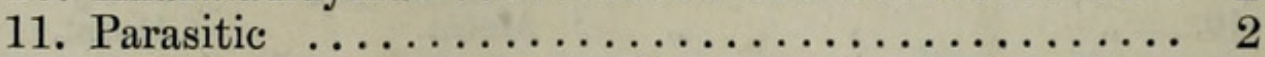




\section{BiBLIOGRAPHY.}

1. Aldrovandus.-Monstrorum Historia (1642), p. 428.

2. v. BAEr.- "Ueb. doppelleibigen Missgeburten." Mém. de l'Acad. Imp. des Sci. de St. Pétersbourg, sér. 6, t. iv. pt. 2,1845 , p. 79 .

3. Jussieu.-Hist. de l'Acad. R. des Sci. 1754, p. 30.

4. J Асовг.-Hannoversch. Mag. 1765, pt. 62.

5. RUdolphi. - (As quoted by v. Baer.)

6. Heusner.-Descr. Monstr. Avium, Amphib. Piscium. Diss. In. Berolini, 1824.

7. Rathke.-Abh. z. Bild. u. Entw. d. Mensch. u. Thiere, Bd. ii. p. 61.

8. KNoch.- "Ueb. Missbild. betr. d. Emb. des Salmonen u. Coregonus Geschlechtes." Bull. de la Soc. Imp. des Nat. de Moscou, t. xlvi. 1873 , p. 173.

9. Klaussner.-Mehrfachbildungen bei Wirbelthieren. München, 1890.

10. St.-Hilarre.-Anomalies de l'Organisation, vol. iii. p. 202.

11. Lereboullet.- "Recherches sur les Monstruosités du Brochet.” Ann. des Sci. Nat., Zool. sér. 4, t. xx. p. 177.

12. RaUber. - "Die Theorien des excessiven Monstra." Virchow's Archiv, t. lxxi. p. 133, \& t. lxiii. p. 551.

13. De Quatrefages.- - Mém. sur la Monst. double chez les Poissons." Mém. de la Soc. Philomath. 1888.

14. Valentin.- “Ein Beitr. z. Entw. d. Doppelmissgeb.” Arch. f. Phys. Heilk. 1851.

15. Sutron.-Evolution and Disease, p. 121.

16. Coste.- "Origine de la Monstruosité double chez les Poissons osseux." Comptes Rendus, xl. pp. 868 \& 931.

\section{EXPLANATION OF PLATE XXV.}

Fig. 1. Head of trout-embryo, showing third median eye.

2. Head of trout-embryo, showing additional, median, pair of eyes.

3. Fission to region of pectoral fins. The left eye of the right fish is absent.

4. Fission to beyond posterior border of yolk-sac. The cephalic ends are twisted so as to lie venter to venter.

5. Fission with subsequent union of the caudal ends, which overlap one another. The tail-fins are double.

6. Parasitism. The specimen is seen from the ventral aspect and the parasite projects from the left side of the autosite as a pointed process. $a$, remains of yolk-sac; $b$, circular patch of pigment representing an eye, 
5. On the Visceral and Muscular Anatomy of Cryptoprocta ferox. By Frank E. Beddard, M.A., F.R.S., Prosector to the Society.

\author{
[Received May 21, 1895.]
}

\title{
(Plate XXVI.)
}

So far as I am aware there is no account of the anatomy of the "soft parts" of Cryptoprocta fero $x$ in zoological literature, excepting only the brain, which was described by Dr. Mivart ${ }^{1}$ from a drawing supplied to him by Prof. A. Milne-Edwards. Prof. MilneEdwards himself, in conjunction with M. Grandidier, gave some years ago $^{2}$ a detailed account of the osteology of the animal ; its external characters are of course well known ${ }^{3}$. Since some interest attaches to this animal as an aberrant Viverrine, I have thought it worth while to bring before the Society a few notes upon the anatomy of its viscera and muscular system. The individual which I dissected was a young male; the coloured drawing which $I$ exhibit (Plate XXVI.) is not of that individual but of the fine adult now alive in the Society's Gardens. I am acquainted with only two coloured illustrations of the animal. The original drawing is contained in the first volume of our 'Transactions,' ${ }^{4}$ and illustrates a paper by Mr. Bennett. The second figure is in the work upon Madagascar by Pollen and Van Dam ${ }^{5}$. Neither of these figures appears to me to be so satisfactory as the water-colour drawing by Mr. J. T. Nettleship, which I now place before the Society.

\section{§ Alimentary Canal.}

The palate has 8 ridges, of which the last three are more or less interrupted in the middle line; they here end in conical papillæ, of which there are plenty scattered between the ridges, and from a fusion between which the latter seem to have arisen.

The tongue (see woodcut, fig. 1) has two circumvallate papillæ on each side, of which the innermost is double. There is no median papilla. Contrary to what is said by Prof. Mivart, I have found them in Genetta (pardina). There is, as in the Cat, a strongly marked patch of spiny papillæ anteriorly.

The stomach is not unlike that of Prionodon, as figured by Dr. Mivart ${ }^{6}$, though deeper. The interior of the cardiac portion is distinguished by numerous longitudinally running folds. These cease absolutely at the constriction which marks the commencement

1 "Notes on the Cerebral Convolutions of the Carnivora," J. Linn. Soc. vol. xix.

2 "Observations anatomiques sur quelques Mammifères, \&c.," Ann. Sci. Nat. (5) vii. p. 314.

3 See Bennett, Tr. Z. S. vol. i. p. 137; Pollen and Van Dam, " Recherches sur la Faune de Madagascar," $2^{\mathrm{e}}$ partie, vol. viii.

4 Pl. xxvi.

B P. Z. S. 1882 , p. 506.

5 Loc. cit. 


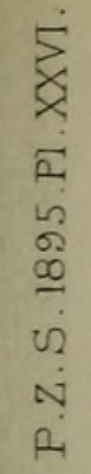


- $154 M U S$

$Z$ 级

(a)

(4) 
of the upward bend of the pyloric region of the stomach. The pyloric valve is not very strongly marked.

The spleen measures from end to end just over two inches. It is considerably wider at one end than the other. At the wide end are indistinct traces of bifurcation as in the Cat.

Fig. 2.

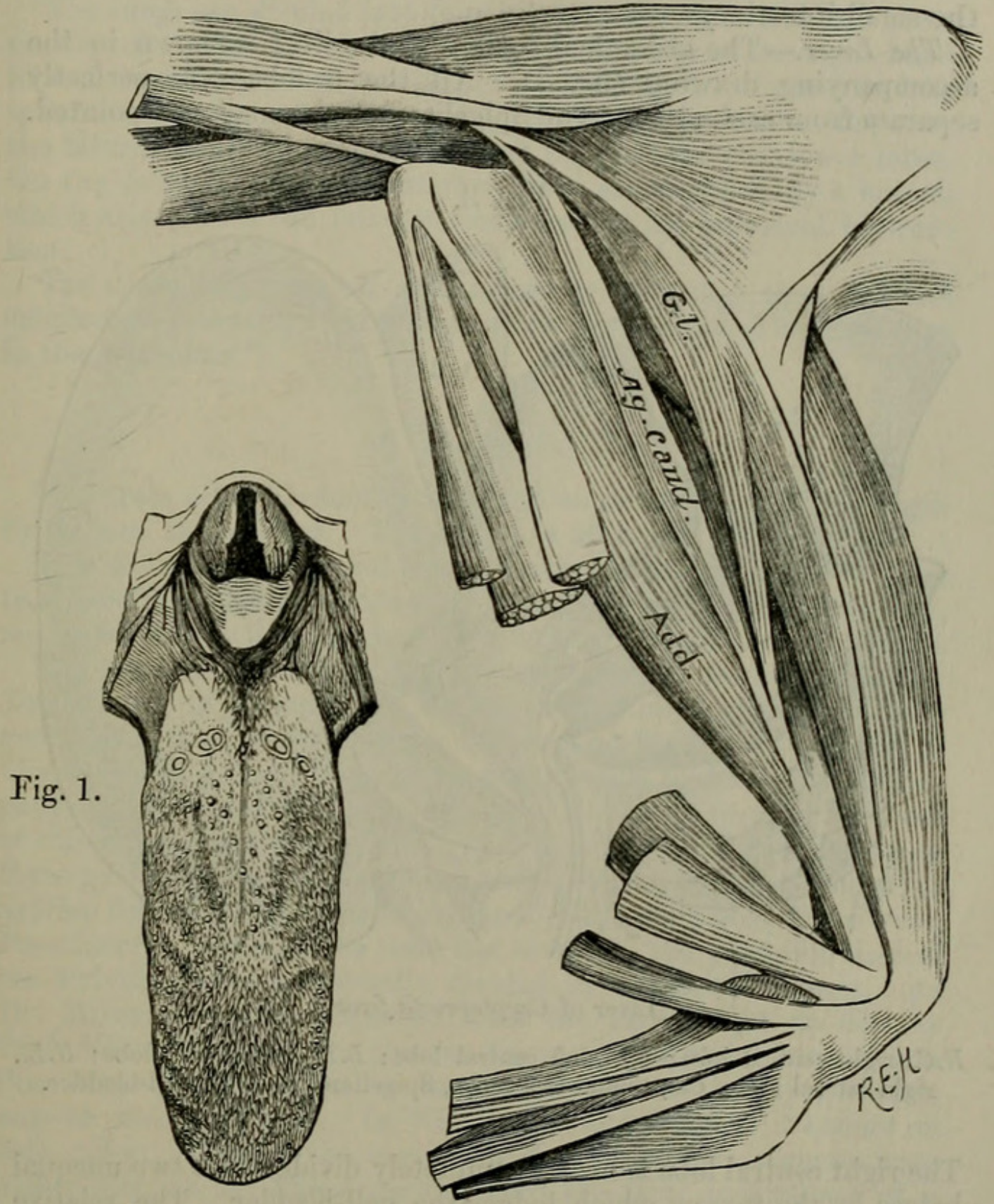

Fig. 1.-Tongue of Cryptoprocta ferox, dorsal surface.

Fig. 2.-Muscles of thigh of Cryptoprocta ferox.

G.l., gluteus maximus; Ag. caud., agitator candæ.

The small intestine measures 55 inches, the large intestine only $6 \frac{1}{2}$ inches in length. There is a very long Peyer's patch, $4 \frac{1}{2}$ inches 
in length, in the small intestine, which ends just at the origin of the cæcum.

The cæcum measures $10 \mathrm{~mm}$. from the apex to the inner side of its junction with the intestine in a straight line. A median anangious sheet of mesentery connects it with the intestine and extends about halfway up it. A blood-vessel crosses the intestine on each side to supply the cæcum, but is not borne upon a mesentery. The cæcum is regularly conical in form, and slightly curved towards the small intestine.

The Liver.-The abdominal surface of the liver is shown in the accompanying drawing (fig. 3). All the 6 lobes are perfectly separate from each other. The Spigelian lobe is small and pointed.

Fig. 3.

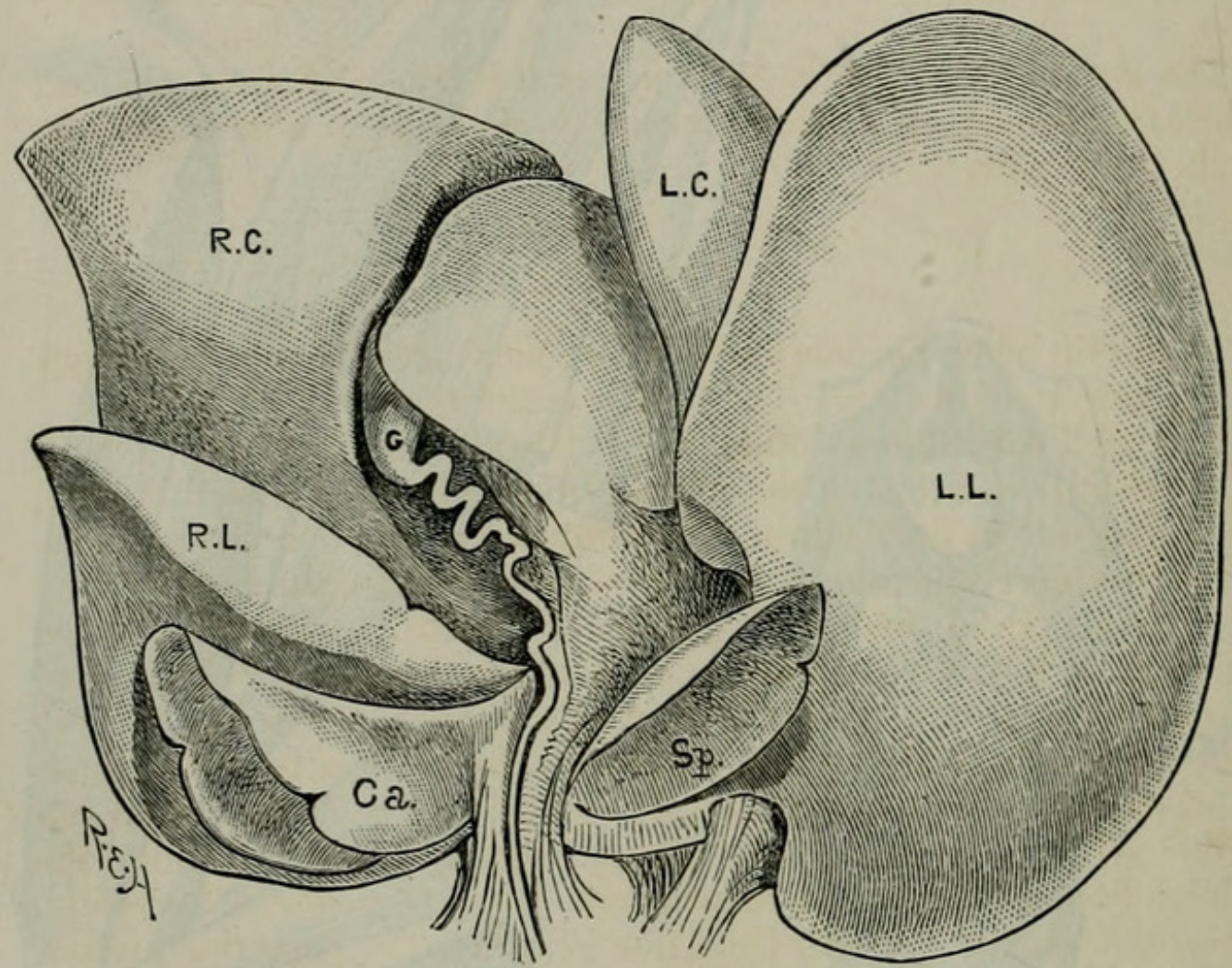

Liver of Cryptoprocta ferox.

R.C., right central lobe; L.C., left central lobe; L.L., left lateral lobe; R.L., right lateral lobe; Ca., caudal lobe; Sp., Spigelian lobe; G., gall-bladder.

The right central lobe is nearly completely divided into two unequal halves by the furrow which lodges the gall-bladder. The relative sizes of the different lobes may be expressed by means of the following formula :-

$$
\text { LL } 2>\text { LC } 2<\text { RC } 3>\text { RL } 2>\text { Ca } 3>\text { Sp. }
$$

For a comparison of the liver of this animal with that of other Ailuroidea I have referred to Dr. Mivart's paper upon the anatomy 
of the group ${ }^{1}$. The liver of Cryptoprocta agrees very closely with that of Herpestes, which is figured in the paper referred to. But no salient differences appear to distinguish the Viverrine from the Feline liver.

\section{§ Organs of Respiration and Circulation.}

The lungs are divided into four lobes on the right side and three on the left. The air-tube supplying the anterior of the right-hand lobes leaves the trachea just before its bifurcation; the middle lobe is served by a branch which springs from the bronchus just after the bifurcation. The bronchus itself supplies the two lower lobes. On the left side the two anterior lobes are supplied by a branch which arises from the left bronchus just at the bronchial bifurcation.

The aortic arch gives off an innominate vein and then the left subclavian separately. This appears to be the general arrangement in the Ailuroidea ${ }^{2}$.

\section{$\S$ The Brain.}

The brain after hardening in spirit measured $51 \mathrm{~mm}$. in length by $35 \mathrm{~mm}$. in diameter. The height is $26 \mathrm{~mm}$.

It is well convoluted and characteristically carnivorous. I have paid careful attention to the convolutions, which, as is well known, are important in determining the affinities of carnivorous animals.

The brain of this animal has, however, already been described by Dr. Mivart in a memoir ${ }^{3}$ dealing with the carnivorous brain generally. But, as his memoir contains no figures of the brain of Cryptoprocta, I have thought it worth while to have the accompanying drawings (figs. 4,5 ) prepared. The brain agrees with those of other Carnivora (except the majority of the Cynoidea) in having three gyri-the Sylvian, parietal, and sagittal — arranged round the Sylvian fissure in the order mentioned. As in Herpestes, Viverricula, Paradoxurus, and Cynictis (but not Genetta), the posterior limb of the Sylvian gyrus is partially divided by a vertical fissure. As Dr. Mivart correctly surmised from the sketch lent to him by Prof. Milne-Edwards, the Sylvian fissure is prolonged back to join this latter fissure. This has happened, however, in my specimen only on the right side. In Viverricula and Cynictis it occurs on both sides. Though the parietal and sagittal gyri communicate posteriorly, as in Paradoxurus, there are faint indications of a separation, as I have shown in the drawing (fig. 4, p. 434). In Paradoxurus there are no such indications. There is, however, a resemblance to Paradoxurus in the commencing division of the

1 "Notes on some Points in the Anatomy of the Ailuroidea," P. Z. S. 1882, p. 510.

2 See Mivart, P. Z. S. 1882 , p. 515 .

3 "Notes on the Cerebral Convolutions of the Carnivora," J. Linn. Soc., Zool. vol. xix. p. 1.

Proc. ZooL. Soc.-1895, No. XXVIII. 
anterior part of the sagittal gyrus lying behind the crucial sulcus by a deep but short fissure into two parts. There are fair traces of this in Paradoxurus; fainter traces in Genetta and Viverricula; none at all in Herpestes and Cynictis.

When the olfactory bulbs are gently pulled down from the anterior edge of the brain, they are seen to have covered a vertical furrow on each side, which are present in Herpestes and Cynictis. In Paradoxurus, Genetta, and Viverricula this fold is more laterally placed, so that it is not concealed by the olfactory bulbs. It will be seen from the brain of Cryptoprocta that there are indications of this furrow, which seems to show that it is not the homologue of the anterior one of Herpestes. Dr. Mivart has hinted that the Sylvian fissure may possibly not be that which I have identified with it in the present paper. In this case the brain will come to resemble that of the dog in having four gyri, and one of the two small fissures marked $b$ in the drawing (woodeut, fig. 5 ) will be the Sylvian fissure.

Fig. 4.

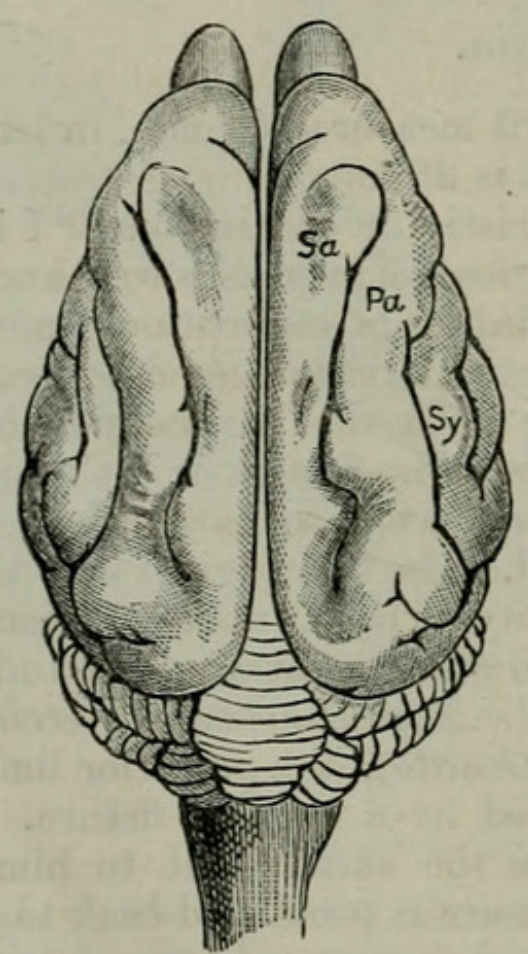

Fig. 5.

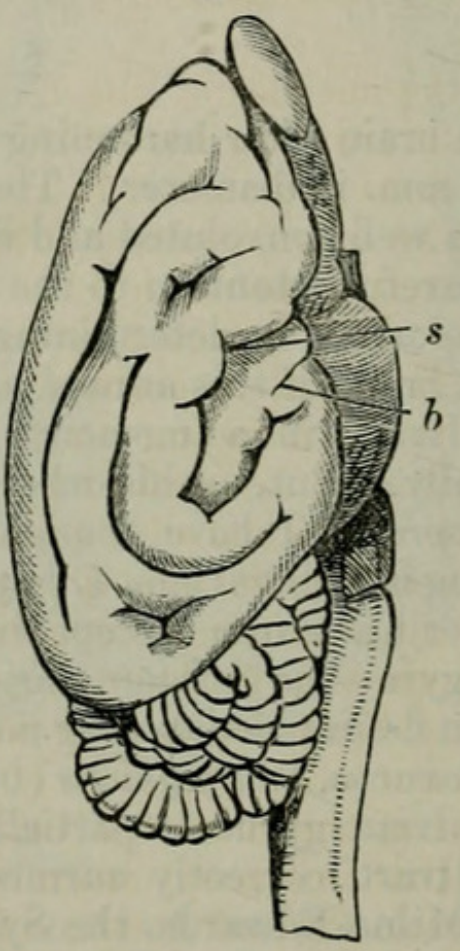

Brain of Cryptoprocta ferox.

Fig. 4.-Dorsal view.

$S a$, sagittal gyrus; $P a$, parietal gyrus ; $S y$, Sylvian gyrus.

Fig. 5. - Lateral view.

$s$, Sylvian fissure; $b$, post-Sylvian fissure.

It will be noticed that the anterior of the two fissures arises from the summit of the angle formed by the pallial fissure, which is in favour of its identification with the Sylvian fissure. On the right 
side of the brain, howerer, this fissure is ouly just indicated, the second of the two referred to being much the most prominent. In Cynictis the fissure in question is present and looks very like a Sylvian fissure; so also in Viverricula. No doubt this is some reason for placing the three genera near to each other. The brain of Herpestes pulverulentus also offers some support to the veiw that the fissure $b$ is the Sylvian fissure; for in this species (and in other species, according to Mivart) the anterior limb of the Sylvian fissure is divided as in the Cats. There is therefore no antecedent improbability in this being the case with Cryptoprocta.

\section{§ Muscles of the Limbs.}

In studying the muscular auatomy of Cryptoprocta, I have used for comparison Genetta pardina, besides the work by Dr. Mivart upon the Cat and his memoir upon the Ailuroidea. Where the Cryptoprocta diverges in the characters of its muscular system from Felis it approaches, or is identical with, the Viverrida, as will be gathered from the following notes upon the principal muscles of the limbs.

Of the muscles of the fore limb I only noticed that two were different from those of Genetta pardina. In the latter the latissimus dorsi is peculiar, in that it gives off a thin branch from near where its origin encroaches upon that of pectoralis major, which is inserted on to the head of the humerus close to the origin of the biceps. Just before the origin of the dorso-epitrochlear a wide slip is given off to pectoralis major. This latter seems to correspond to the blending "with adjacent fibres of the fourth part of the pectoralis" described by Dr. Mivart in the Cat.

These additional slips are not present in Cryptoprocta, which, like the Civets, has but one dorso-epitrochlear.

The other difference concerns the extensor minimi digiti. I found that this muscle in the Cryptoprocta supplied digits iii., iv., and v., the slip to v. being for a long way up a separate muscle. In Genetta pardina it only supplied iv. and v. But the distribution of the tendons of this muscle is evidently variable; for while Dr. Mivart found that in the specimen of Genetta tigrina dissected by himself the muscle gave off tendons to all three digits, he quotes Cuvier to the effect that in "the Genet" only iv. and v. receive tendons.

The biceps has but one head, as is the rule with these Carnivora.

The teres major is inserted distinctly in common with the latissimus.

The triceps appeared to me to be rather four-headed, as in Viverra civetta, than five-headed, as in the Genet.

The flexor sublimis gives off a tendon to the flexor profundus. It supplies the three middle digits only.

The flexor profundus has four rather than five bellies; five if the connection with the flexor sublimis be counted.

The extensor secundi internodii pollicis supplies digits i. and ii. 
Both in the fore limb and in the hind limb the muscles of the Cryptoprocta were easy to dissect, owing to the absence of strong fasciæ; this is perhaps related to the youth of the individual.

Fig. 6.

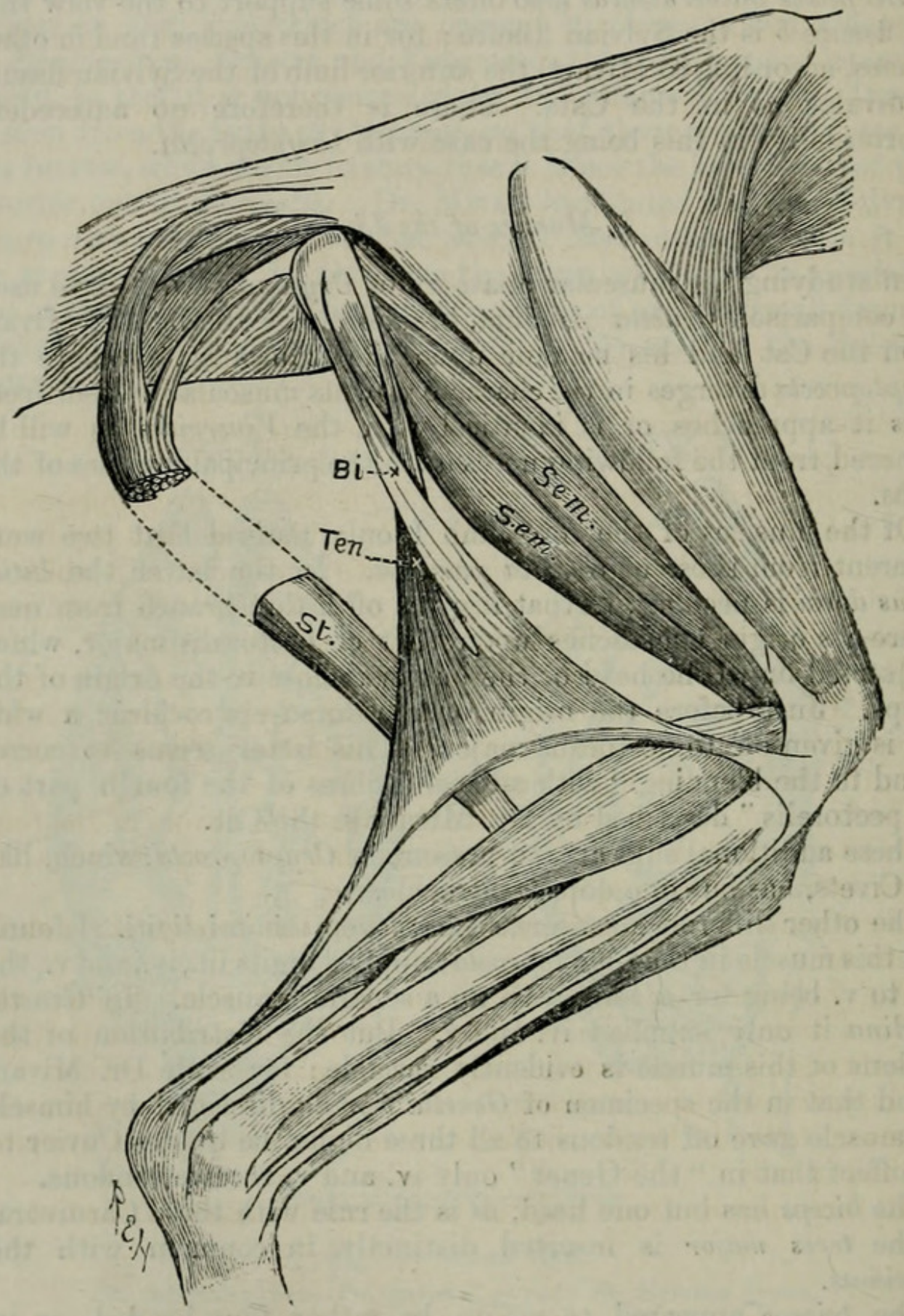

Muscles of thigh of Cryptoprocta.

Bi., biceps ; Sem., semimembranosus ; Ten., tenuissimus ; St., semitendinosus.

One of the most interesting muscles of the hind limb is the semimembranosus (see fig. 6). In the Cat it is partly divided into 
two parts; in the Genet the "two parts are more separate." Finally, in Cryptoprocta the two parts are absolutely separate, save for an extremely minute tract at their origin. The two parts of the muscle are equi-sized. The part which arises from the tuberosity of the ischium is tendinous at origin and is inserted on to the tibia.

The semitendinosus has the same double head of origin that characterizes the Genet and Civet, as is shown in the accompanying drawing, where the muscle is cut and reflected. The two parts join nearly halfway down femur, and there is, as Prof. Mivart remarks of the Genet, a slight connection with the tenuissimus.

The biceps arises from the ischial tuberosity just below the semitendinosus; the tenuissimus arises a little way in front of it. The two join as is shown in the illustration (woodeut, fig. 6).

The gracilis is like that of the Cat.

The sartorius was not double; it is very wide at insertion.

In the quadriceps femoris complex all four parts were well developed and distinct; the origin of the crurceus goes right up to the neck of the femur.

An agitator caudce (see fig. 2, p. 431) is present in Cryptoprocta, as in the Genet but not in the Cat. It is inserted into the femur by a longish attachment in common with a slender slip which is detached from the second part of the glutceus maximus (that part which is inserted on to the outer condyle of the femur).

The gastrocnemius is only two-headed, the two heads arising, of course, from the two condyles of the femur; from external condyle in common with outer head arises the plantaris. The soleus arises from the head of the fibula only.

There are no special remarks to offer upon the flexors of the foot, except to state that the accessorius is as in the Civet, and thus the flexor brevis digitorum is in one mass.

The tibialis is not double, except just in the tendon for a short distance.

The extensor communis digitorum goes to four digits; the tendons arise from the muscle in order of notation, but they all pass through the ligamentous loop at the ankle-joint together.

The extensor longus hallucis is close to the tibialis; its muscle, however, extends below the muscle of the tibialis; it supplies the hallux only.

All three peroneals are present with attachment as in the Cat. 
6. List and Distribution of the Land-Mollusca of the Andaman and Nicobar Islands, with Descriptions of some supposed new Species. By Lieut.-Col. H. H. Godwin-Austen, F.R.S., F.Z.S., \&c.

[Received May 21, 1895.]

I. Introductory Remarks, p. 438.

II. Table of Distribution, p. 441.

III. Notes and Descriptions of new Species, p. 446.

\section{Introductory Remarks.}

The molluscan fauna of the Andaman and Nicobar Islands has received, since their occupation, a considerable amount of attention at the hands of many good naturalists and collectors. The first collection was made in 1846 by the staff attached to the Danish frigate 'Galathea,' commanded by M. S. Bille, at the time Denmark was in possession of the Nicobar Group: this was described by Professor A. C. L. Mörch, of Copenhagen. This expedition, sent by King Christian VIII., was very well organized : there were three zoologists, Professors Behn of Kiel, J. Reinhardt of Copenhagen, and Kjellerup, two botanists, Drs. Didrichsen and Kampioner, and a geologist, Dr. Rink; the Prussian botanist Th. Philippi also became attached to the expedition.

Of the above, Prof. Reinhardt paid most attention to the Mollusca.

In 1858 the Austrian frigate 'Novara' visited the Nicobars, but no material addition was made to what had been already obtained there.

After the formation of our great penal colony at Port Blair, many other naturalists from time to time visited the Andamans, and received every possible assistance from the Chief Commissioners in charge. Among those who thus helped to swell the list of the Land-Shells we can record the names of Colonel Haughton, Ferdinand Stoliczka, V. Ball, J. Wood-Mason, Major Wilmer, \&c. ; and Benson described a good many species.

Through the kindness of nearly all these collectors I have been able to secure specimens. My brother, Harold Godwin-Austen, was for several years an Assistant-Commissioner at Port Blair, and visited many parts of the islands before unexplored; he collected for me and sent home a number of species preserved in spirit, which have proved of great value.

Lastly, I have had the very large collection formed by another Assistant at Port Blair, Mr. F. A. De Röepstorff, placed in my hands by his widow.

This officer was the son of the last Danish Governor of the Nicobars, subsequently ceded to Great Britain. He was an inde- 
fatigable collector, and he added many new species to the list. As Mörch states quite truly, Copenhagen was, one may say, at this time the capital of the science of conchology, it being sufficient to mention the names of Müller, Chemnitz, Spengler, Fabricius, and Regenfuss.

With this previous work and material I am enabled to give a very full list of what has been obtained there ; it does not profess to be exhaustive, as I am aware that collections are constantly arriving in this country, but I trust the list will be useful for others to add to. For instance, I know of no Land-Shells having been found on either of the small volcanic islands, and it would be of great interest if any should occur, having reference to the means whereby such forms can be transported.

The difficulty of landing on many of these rocky islets, and of getting back to the ship, is so great that very few opportunities occur, and then the time on shore is very limited, so that a good deal has yet to be done. It is remarkable how very few species range beyond the islands on which they have been found; thus there are only 8 species common to the Andamans and Nicobars, while only 7 range on the south to Sumatra and Java, and only 5 north to Burmah. However, there is a distinct and close relationship in the past shown with Burmah and Arakan by so many closely allied species, and equally marked is the paucity of forms having an alliance with those of Peninsular India. Marked diversity of form and restricted range is displayed among the Operculates, in Cyclophorus especially, by the turbinate shells of C. leai, C. foliaceus, \&c., while Alycaus and Diplommatina are very limited in species. No species of Clausitia has yet been recorded from the Andamans, and only three from the Nicobars, and they are very close allies.

The genus Microcystina is represented by several species; although $M$. cryptomphala from Lower Bengal was placed in it by me, yet, as its anatomy is not known, this extension of the range is not certain. Five species occur in Borneo, but the animal has yet to be examined.

The genus Plectopylis, so common in Burmah and N.E. India, is absent. It is interesting to note the occurrence of Omphalotropis, a genus represented by numerous species in the Mauritius, and here represented by 7 species; but it does not occur in India or on the mainland beyond the Andaman Sea. Hyalimax is another genus with a similar range. The physical features of this group of islands have been treated of by many authors, and their position, as regards the whole volcanic line of action, is now defined as one lying outside and to the west of it, and having its extension to the south-eastward in the Nias Islands off Sumatra.

Blanford and Medlicott, in the 'Manual of Geology of India, vol. ii. p. 732, may be consulted; an interesting account by Mr. A. O. Hume and the other members of an expedition to the islands is given in 'Stray Feathers,' vol. ii. (1874). Still later Dr. Prain, in the 'Proceedings of the Asiatic Society of Bengal,' April 1892, 
and in the 'Journal' of the same Society, 1893, has given an account of his collections principally of the flora of Narcondam and Barren Island; although he mentions the presence of landcrabs, spiders, scorpions, and ants on Narcondam, no Mollusca are recorded.

All the above-mentioned air-breathers, it is quite possible, might reach this island on trees floated off from the Andamans during the monsoon which blows so long from that direction, and they would all have a better chance of survival in sea-water than LandMollusca, and might be carried for long distances inside the joints of the bamboos and large grasses.

Dr. Prain publishes two good maps of the Andaman Group, and the lines of soundings ranging from 100 to 2000 fathoms are shown. These point out very clearly, as he shows, that the Andaman Sea, as a physical feature, is distinct from the great oceanic depression outside, which he terms the sea of Bengal, down to about $5^{\circ}$ north.

These contour-lines of soundings also show how the western face of the Andaman-Nicobar line of elevation suddenly descends into the deep water of about 10,500 feet in a distance of from 60 to 70 miles, and this is proportional nearly to the elevation of the Arakan range above the sea, on latitude $22^{\circ}$, near the head of the Bay of Bengal and to its distance from the present sea.

The parallel contour-lines of soundings down to the 1000 -fathom line extend north up the coast of Arakan, and south close to the islands off the coast of Sumatra, Nias, \&c., indicating a former extension of land upon this line.

It is said that the Andamans present evidence of recent subsidence $^{1}$, and these charts of Dr. Prain's show that an elevation of 600 feet in this single group would unite them to Pegu and Arakan, leaving an extremely narrow channel of only 50 fathoms deep south of Preparis. The Nicobars are more isolated, and deep wide channels separate them from the Andamans on one side and Sumatra on the other, which accords with the paucity of Land-Shells common to both, and the presence of a few found in Sumatra. That these islands have been cut off for a considerable period from the adjacent continents and islands is shown not only in the specific variation of the molluscan fauna, but equally in the birds by a great number of distinct and peculiar forms.

A great deal yet remains to be done: the highest parts of the Nicobars have never been collected on; here we may yet find species identical with those of the Andamans, for many obtained there come from the higher elevations, while most of those from the Nicobars have been taken near the sea-coast; and a few hundred feet of elevation would bring in quite a different set of forms.

I S. Kurz, 'Report on the Vegetation of the Andaman Islands.' 


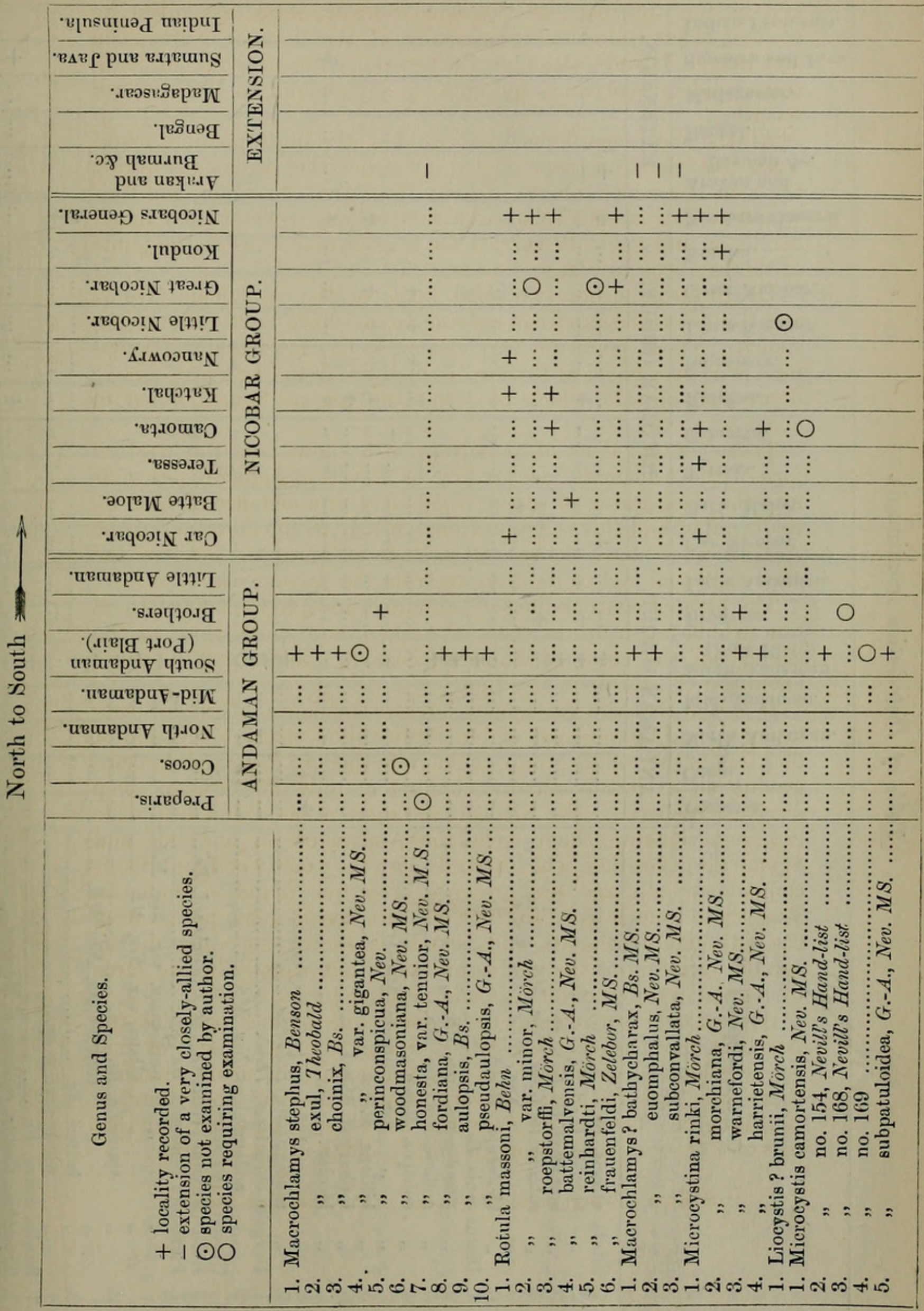


LT.-COL. H. H. GODWIN-AUSTEN ON THE LAND- [May 21,

\begin{tabular}{|c|c|c|}
\hline 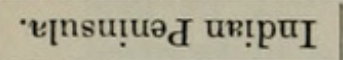 & \multirow{5}{*}{ 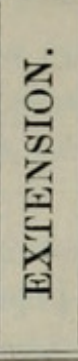 } & \\
\hline вaвf pue в.девuns & & + \\
\hline 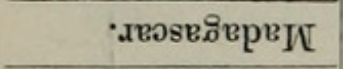 & & $\vdots$ \\
\hline 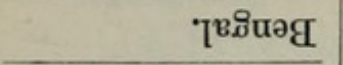 & & $\vdots$ \\
\hline 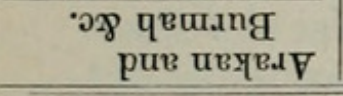 & & +1 \\
\hline 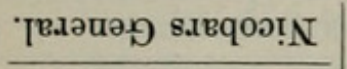 & \multirow{10}{*}{ 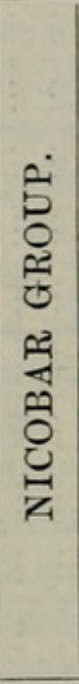 } & $++\quad \vdots$ \\
\hline 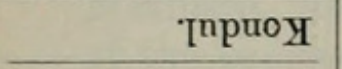 & & $\vdots \quad \vdots$ \\
\hline 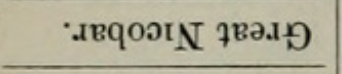 & & $++\vdots$ \\
\hline. & & $++\vdots$ \\
\hline -А.тмолив $\mathrm{N}$ & & $+\quad+\quad \vdots$ \\
\hline [виртву & & $\vdots+++$ \\
\hline •вұлотия & & $\vdots+\vdots \vdots \vdots$ \\
\hline 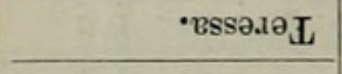 & & $\vdots \vdots \vdots \vdots+$ \\
\hline 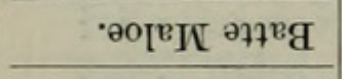 & & $\vdots \vdots \vdots \vdots \vdots$ \\
\hline 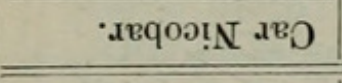 & & $\vdots \vdots \quad \vdots \vdots$ \\
\hline 'ившериу өгभ!т & \multirow{7}{*}{ 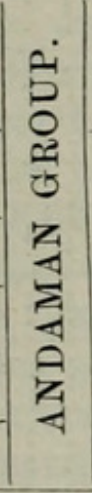 } & $\vdots \vdots \vdots \vdots \vdots$ \\
\hline 's.әтұл.xg & & $\vdots++\vdots \vdots \quad \vdots \vdots \vdots \vdots \vdots$ \\
\hline 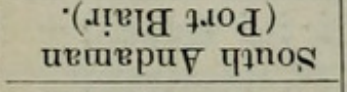 & & $+++\vdots \vdots \vdots+++\vdots \vdots \vdots \vdots \vdots++0+++++++\vdots+\vdots$ \\
\hline 'ививрит-р!п & & $\vdots \vdots \vdots \vdots \quad \vdots \quad \vdots \quad \vdots \quad \vdots \quad \vdots \quad \vdots \quad \vdots \quad \vdots \quad \vdots \quad \vdots \quad \vdots \quad \vdots \quad \vdots \quad \vdots \quad \vdots \quad \vdots \quad \vdots \quad \vdots \quad \vdots \quad \vdots \quad \vdots \quad \vdots \quad \vdots \quad \vdots$ \\
\hline 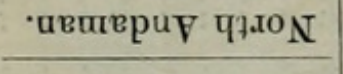 & & 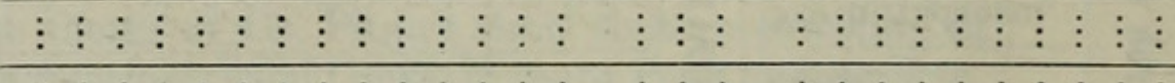 \\
\hline .80000 & & 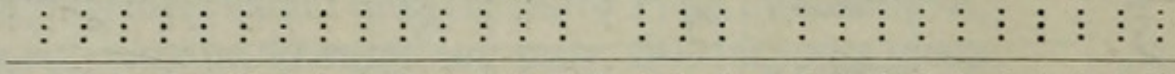 \\
\hline ș̣.redə.x & & 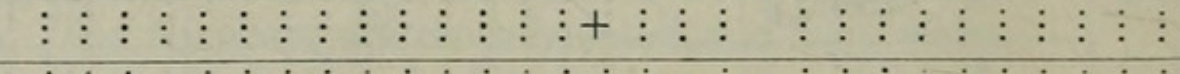 \\
\hline \multicolumn{2}{|l|}{ 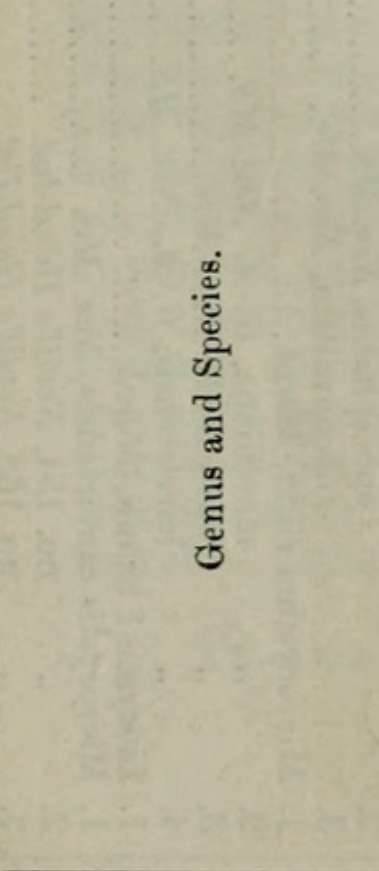 } & 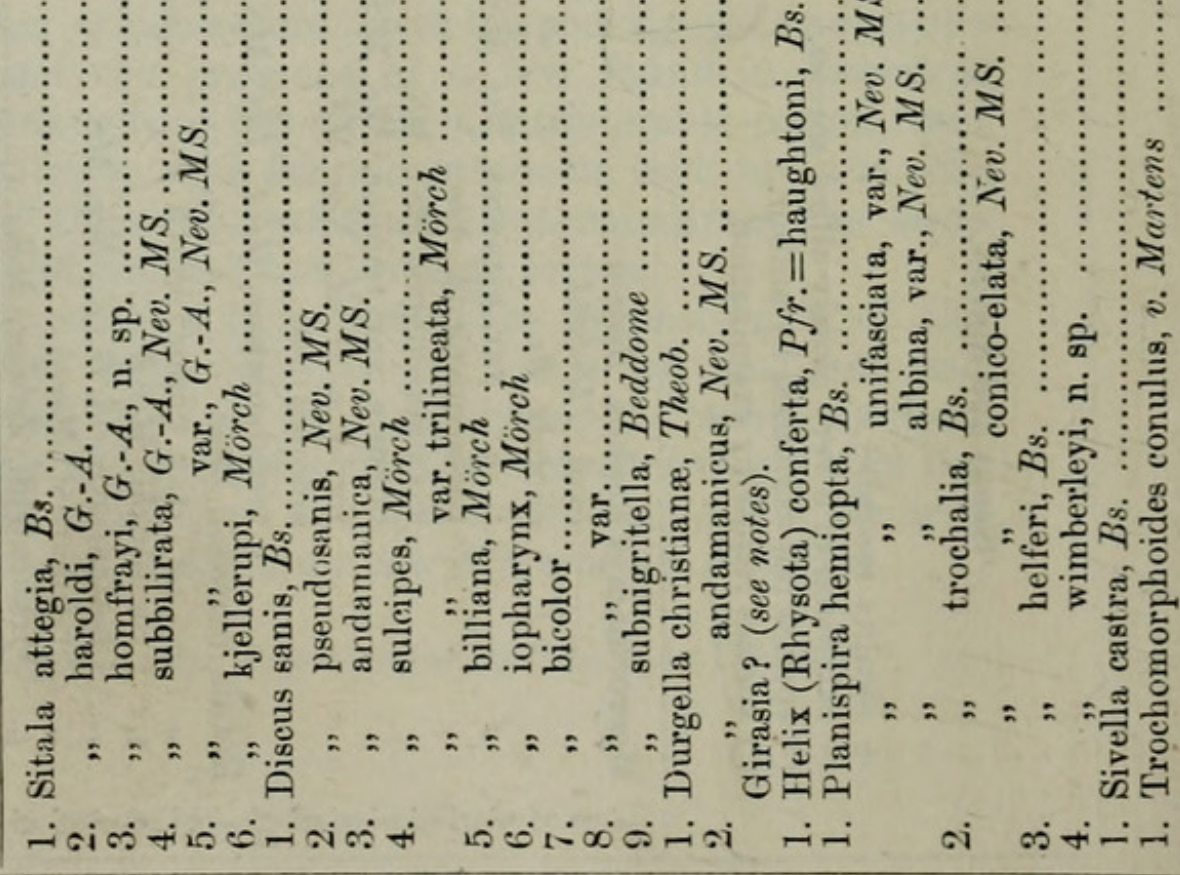 \\
\hline
\end{tabular}


1895.] MOLLUSCA OF THE ANDAMAN AND NICOBAR ISLANDS. 443

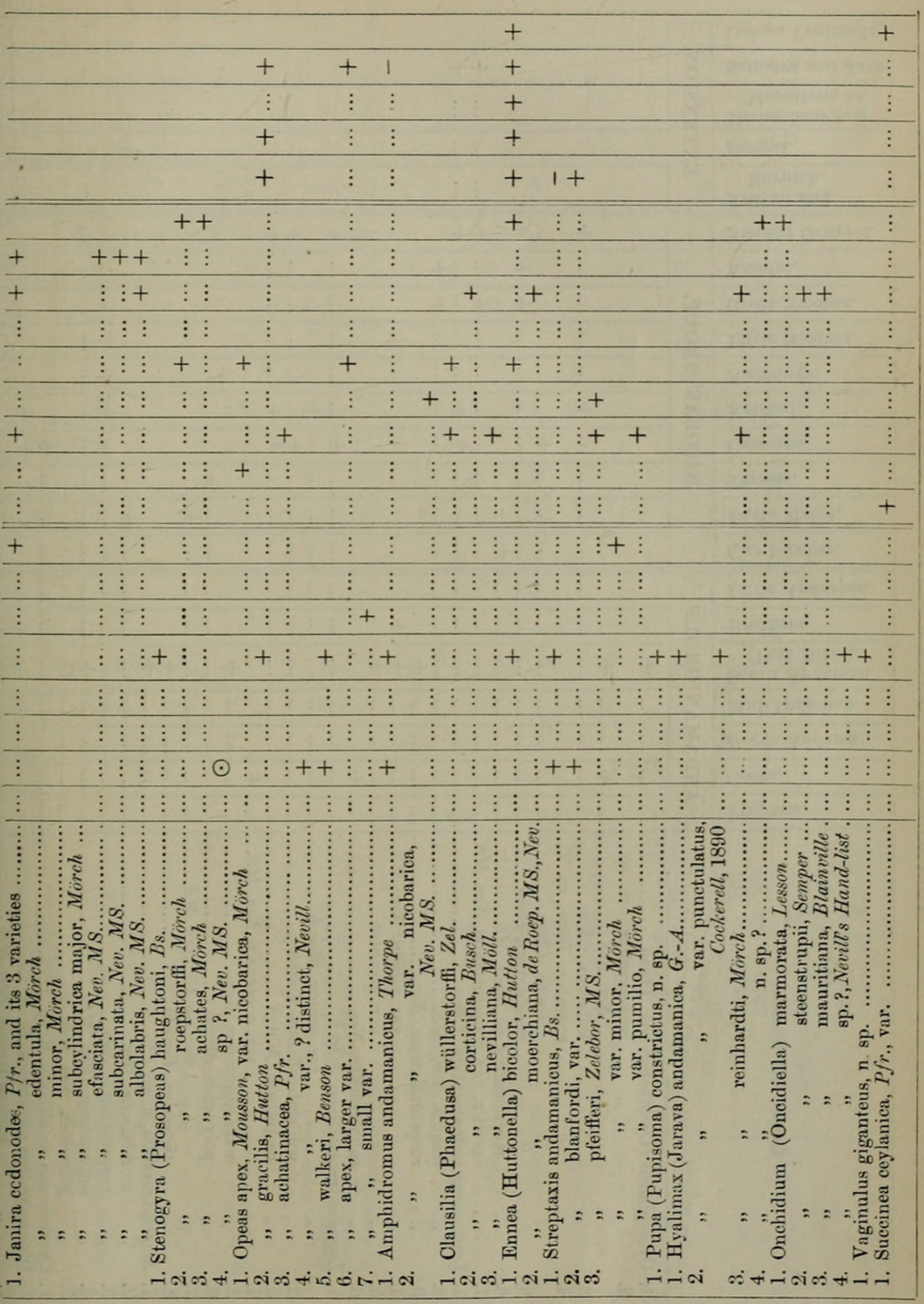




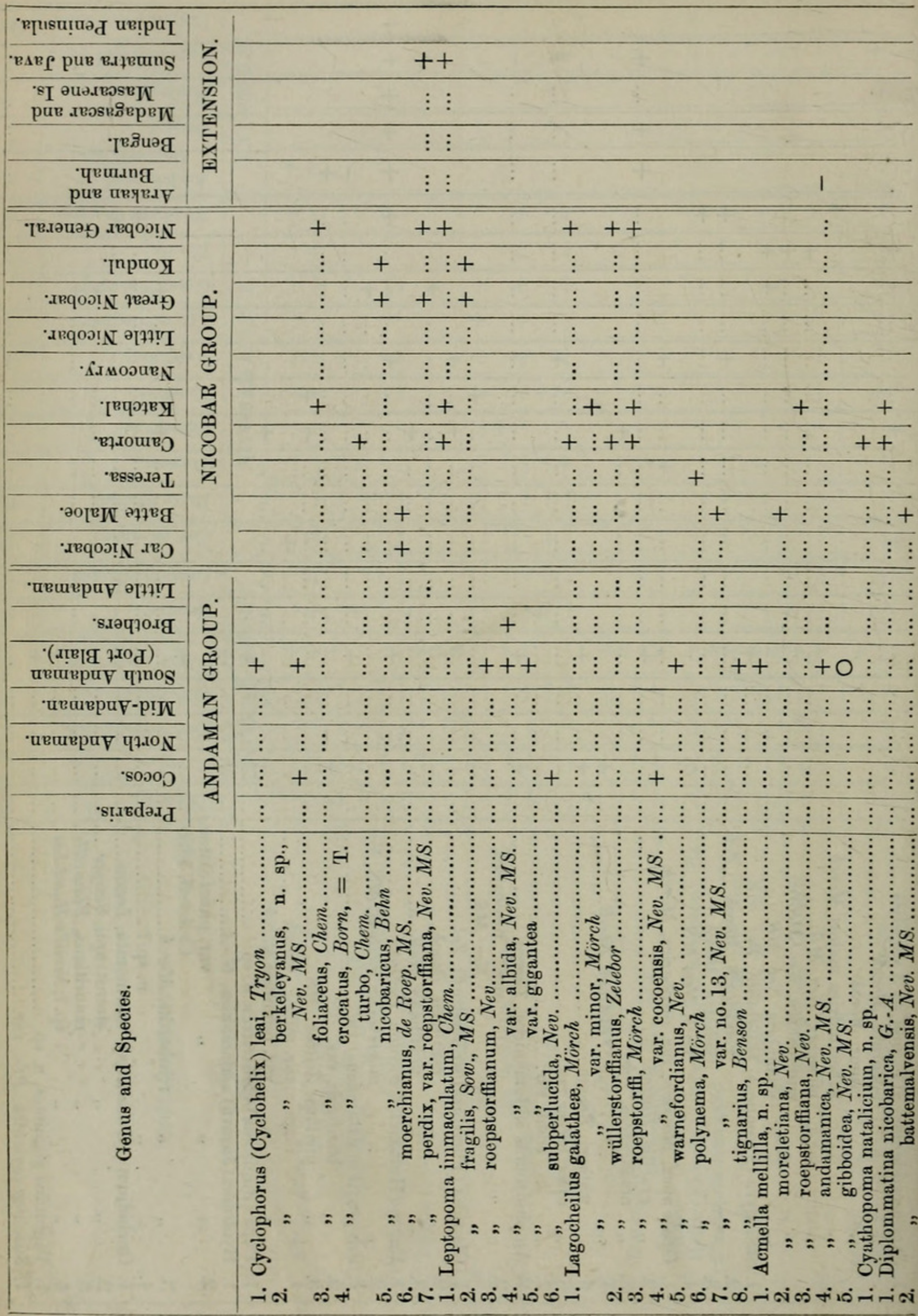









\section{Notes and Descriptions of new Species.}

\section{Genus Macroohlairys.}

\section{Macrochlamys? stephus, Bs. (p. 441).}

This species has a small left shell-lobe, shaped as in Cycloplax (see fig. 4, pl. xxxi., Land and Freshwater Moll. Ind.). Jaw with prominent central projection.

It therefore does not, so far as the mantle is concerned, agree with typical Macrochlamys. Better spirit-specimens are required for examination.

4. Macrochlamys choinix, var. gigantea (p. 441).

In a MS. copy of Nevill's 'Hand-list' M. gigantea is catalogued as a variety of choinix-" ? a distinct species. Collected by F. A. de Roepstorff, Esq. Diam. 19.25; alt. $10 \cdot 25$ mm." I have not seen an example of this species.

6. Macrochlamys woodmasoniana, Nevill MS. (p. 441).

This species is no. 33 of Nevill's 'Hand-list' (p. 23). The type is in the Indian Museum, Calcutta, obtained by Mr. J. WoodMason.

7. Macrochlamys honesta, var. tenuior (p. 441).

This species is recorded in Nevill's 'Hand-list' (p. 24) as the Moulmein variety; and this is the typical locality, and collected there by Stoliczka and Theobald. It is also recorded from Preparis Island, the most northerly of the Andaman Group, from the collection of Ferd. Stoliczka. I have in my own collection three specimens given me by Stoliczka, undoubtedly a variety of honesta, but the locality marked on the label is "Nicobar?"; so I refrain from describing it at present.

8. Macrochlamis fordiana, G.-A. (p. 441).

This species is no. 39 of Nevill's 'Hand-list'; it was unnamed when the catalogue was published. In his MS. catalogue Nevill has entered it as fordiana in ink, and microsculpta in pencil. Four specimens collected by Colonel Ford are the types in the Indian Museum; six specimens are recorded from Mr. de Roepstorff. I adopted the title fordiana, though I find microsculpta on labels in de Roepstorff's shells that have come to me. This species was described by me in the 'Annals and Magazine of Natural History' (ser. 6, ii. p. 57, 1888).

9. Macrochlamis aulopsis (p. 441).

Nanina aulopsis, Bs.

Thalassia in Nomenel.

This is a true Macrochlamys. The right shell-lobe is well developed, the left was not well made out. The odontophore is similar to that of the above genus, the formula being $20-8-1-8-20$ about. 
Generative organs.-The male organ is long, and the amatorial organ is present.

The margin of the branchial sac from anal orifice is conspicuously mottled with black and white showing through the shell. It has a peculiar capreolus, or spermatophore, like $M$. jainiana, G.-A., from Parisnath, Land \& Freshw. Moll. India, pl. xxviii. figs. $2 b, 2 c$.

10. Macrochlamys pseudaulopsis, G.-A., Nevill MS. (p. 441).

This is No. 108 of Nevill's 'Hand-list' (p. 32) and described by me $(l . c$.$) . This name occurs on labels in Mr. de Roepstorff's$ collection in Nevill's handwriting.

The jaw in this species is very much curved with strong central projection. It possesses the amatorial organ.

\section{Genus Rotula.}

1. Rotula massoni, Behn (p. 441).

Helix massoni, Behn, Pfr. Mon. Hel. iv. p. 344 (1859).

Rotula massoni, Semper, Reise, p. 40, pl. iii. f. 28, pl. vii. f. 17.

Nanina (Rotularia) massoni, Mörch, Journ. de Conch. sér. 3, xii. p. 308 (1872), et xvi. p. 354 (1876).

This shell was described from a single example.

The animal has a small right shell-lobe and one small left shelllobe as in Macrochlamys. It is very pale in colour with black tentacles.

The odontophore is also as in Macrochlamys.

Jaw with a central projection.

$$
20 \text { to } 25-12-1-12-20 \text { to } 25 \text {. }
$$

Semper on plate vii. gives the form of the teeth exactly; his specimen was from the Museum at Kiel, ex coll. 'Galathea.' The generative organs are also figured by Semper; it has no amatorial organ, and in this respect it coincides with coelatura and mufa, both from Bourbon, the home of detecta, which Albers took as the type of his genus Rotula.

I am inclined to think that $R$. roepstorffi is only a synonym, the transverse sculpture on the apical whorls would disappear in old shells.

\section{Genus Microcrstina.}

3. Microcystina warnefordi, Nevill MS., G.-A. (p. 441).

This genus and species are described by me in the 'Land and Freshwater Mollusca of India' (p. 13, pl. iii. f. 8).

Jaw very curved, central projection well developed.

\section{Genus Microcystis.}

1. Microcystis Camortensis, Nevill MS. (p. 441).

A specimen of this species is in the Calcutta Museum, collected 
by de Roepstorff. I have not seen it; it is recorded in Nevill's MS. copy of the 'Hand-list.'

\section{Genus Sitala.}

2. Sitala haroldi, G.-A. Moll. Ind. p. 33, pl. x. figs. 7,7 a (p. 442).

This species is no. 200 of Nevill's 'Hand-list' (p. 41); his Microcystis stewartiana, MS., but never described. Nevill gives its locality as Little Brother Andaman and Katchal, from de Roepstorff. No. 208 in the 'Hand-list' from Batte Malve, Nevill thinks is the same species.

3. Sitala homfrayi, n. sp. (p. 442).

Locality. South Andaman (de Roepstorff).

Shell dextral, pyramidal, turreted, flat on base, imperforate; sculpture coarse transverse striation, with two ribs on the periphery and fine spiral close ribbing on the apical whorls; colour horny grey; spire conic; apex blunt and papillate; suture shallow : whorls $4 \frac{1}{2}$, sides angulate, a strong raised rib on the periphery of the last whorl, and another similar rib above it at the angulation of the whorl, above the vertical portion; aperture ovately quadrate, very oblique; peristome thin, slightly thickened; columellar margin vertical.

Fig. A.

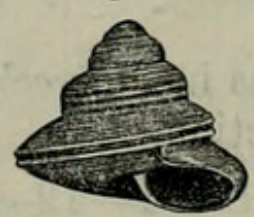

Sitala homfrayi. $\times 12$.

Size : maj. diam. 1.4 ; alt. axis $1.4 \mathrm{~mm}$.

This is a form allied to Sitala subbilirata and S. tricarinata, and is of the same minute size as the latter, but it differs from it in the pyramidal form and smaller narrower aperture.

It occurred among a lot of small shells. I name it after Mr. Homfray, whose name is so well known as a first worker among the aboriginal inhabitants of these islands.

\section{Genus Discus.}

1. Discus sanis (p. 442).

Nevill, in a MS. note, says " animal throughout of a jet-black colour."

3. Discus andamanica (p. 442).

Nerill describes this species as follows:- "The animal is quite different from that of $T$. sanis, being throughout whitish with grey tentacles. Shell more deeply solariformly umbilicate, bordered by an acute keel; spire more raised; whorls more closely wound; of lighter colour." 


\section{Genus Durgella.}

\section{Durgelda andamanicus, Nevill MS. (p. 442).}

I have not seen this species. It is entered in the 'Hand-list.' 10 in the Calcutta Museum (10 in spirit), type Andamans from de Roepstorff, " has been taken for the young of Durgella christiance," which is not unlikely to be the case.

\section{Genus Girasia.}

Girasia, sp. inc. (p. 442).

My brother described having found, when he made the ascent of Saddle Peak on North Andaman with Col. Hobday of the G.T. Survey, a large slug-like form resembling this genus. It was done up in leaves, but was accidentally lost before they got into camp. This genus may therefore be sought for by future collectors.

\section{Genus Planispira.}

4. Planispira wimberleyi, n. sp. (p. 442).

Locality. Nicobars (de Roepstorff).

Shell depressedly orbiculate, narrowly umbilicated, very finely hirsute; sculpture, when this is abraded the surface is covered with minute regular papillation, which is much coarser than that of $H$. helferi ; colour horny grey ; spire rounded ; apex rounded; suture impressed; whorls 4 , not fully developed, slightly convex; aperture and peristome probably slightly expanded and reflected.

Size : maj. diam. $10 \cdot 2$, min. 8.9 ; alt. axis $5.7 \mathrm{~mm}$.

This species is nearest to $H$.helferi, but may be distinguished by its narrower umbilicus and the great difference in sculpture, and the whorls above are not so flat. This is probably no. 102 of Nevill's 'Hand-list' (p. 76), collected by Ferd. Stoliczka.

Planispira helferi, Benson, has only hitherto been found in the Andamans ; the young shell of four whorls and banded I found in Mr. de Roepstorff's collection from the Nicobars; but it might have got among them accidentally, and therefore this new habitat has to be confirmed.

\section{Sivella castra, Blandf.}

\section{Genus Sivella.}

A variety is recorded by Nevill, 'Hand-list,' p. 56, from the Andamans and a single specimen is in my collection from Mr. WoodMason.

The umbilicus is wider than in castra and the apex far flatter. Sculpture quite smooth below, with transverse striæ; whereas castra from typical locality, of same size, has close spiral striation most distinct. There is also a remarkable difference in the suture, the Andaman shell has a fine beading running into it, produced by the sharply defined carinate edge of the shell. I believe this to be only an immature Discus sanis.

Proc. Zool. Soc.-1895, No. XXIX. 
I have lately, in a paper read at the Malacological Society, referred to the distinctness of this genus Sivella, constituted by W. T. Blanford for the-Indian species castra, which he made the type. It differs in every respect from Discus, represented by bicolor, sulcipes, \&c. ; the anatomy of the latter I have been able to examine in specimens sent me by my brother from the Nicobars.

\section{Genus TrochomonpHoides.}

1. Trochomorphoides conulus, Martens (p. 442).

Katchall (de Roepstorff).

Size : maj. diam. $11 \cdot 2$, min. $10 \cdot 2$; alt. axis $11 \cdot 0 \mathrm{~mm}$.

\section{Genus Amphidromus.}

2. Amphidromus andamanicus, var. nicobarica, Nev. MS., Hand-list, p. 127 (p. 443).

Of this species I have one specimen from Katchall. It is somewhat larger than Andaman shells, and in colour is far paler and with few markings, and those pale. These differences might not hold good in a large series.

\section{Genus Ennea.}

2. Ennea (Huttonella) moerchiana, De Roepstorff MS. Nevill, Hand-list MS. (p. 443).

This species comes nearest to E. stenopylis of the N.E. frontier.

\section{Genus Streptaxis.}

1. Streptaxis andamanicus, var. (p. 443).

This species comes near S. blanfordi, Theobald.

From Arakan and Pegu.

\section{Genus Pupa.}

1. Pupa (Pupisoma) constrictus, n. sp. (p. 443).

Locality. South Andaman (de Roepstorff).

Shell turbinate, perforate; sculpture minutely costulate above, from the swollen portion forwards the surface is smoother; colour, pale ochraceous; spire conic; sides flat; apex pointed; suture impressed; whorls 5 , convex, at the distance of half a turn in the spiral behind the aperture there is a sharp swelling of the whorl, marking apparently the position of the previous aperture, but this is not seen in any of the whorls above; aperture ovate, oblique; peristome much thickened and reflected, united by a thin callus on the body-whorl; sinuate below and on outer margin.

Size: maj. diam. $2 \cdot 1$; alt. axis $2 \cdot 2 \mathrm{~mm}$.

Animal not yet seen, and it is difficult to say where this species should find generic position. I sorted out from a tube full of 
minute shells eight specimens of this very curious and interesting species.

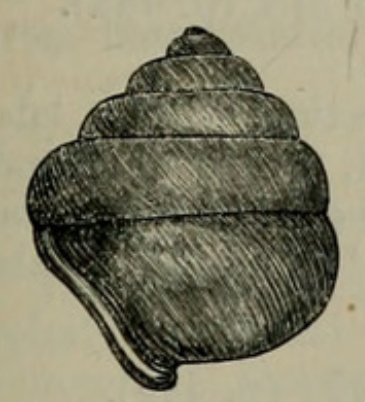

Fig. B.
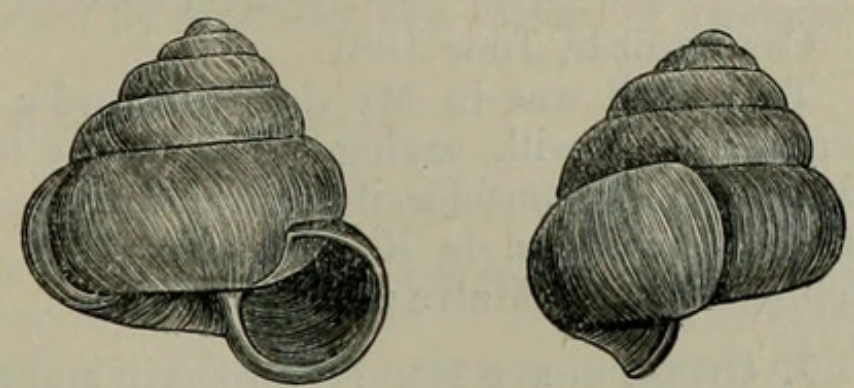

Pupa (Pupisoma) constrictus. $\times 12$.

Its sculpture is like that of Pupisoma lignicola, Stol., from Moulmein, and I think it better to place it near this than to create a new genus for it, which I at first intended; I think it is best, however, to wait until some one else can examine the animal.

\section{Genus Vaginulus.}

\section{Vaginulus giganteus, n. sp. (p. 443).}

Locality. Andaman Islands (Harold Godwin-Austen).

Animal elongate in form. Total length $68.0 \mathrm{~mm}$; total breadth $23 \cdot 0$; breadth of foot $9 \cdot 0$; female orifice 28.5 from the extremity of the foot, 6.0 from the middle line of the foot, 1.5 from the pedal groove. The colour in the spirit-specimen is above grey, with dark mottlings, paler near the head, and a narrow pale line down the centre of the back; below dull ochre. Upper surface smooth to the eye, under the lens closely pitted. The sole of the foot narrow, slightly wider than the adjacent under surface. The foot is crossed by rather close, very regular folds, which form distinct grooves across it, very even in width; there are 22 such folds in $10 \mathrm{~mm}$. of length, and each transverse fold is divided by a very fine secondary groove. The tentacles, although contracted, are large.

This is a remarkably large species, $13 \mathrm{~mm}$. larger than anything described by Semper from the Indian region; the largest mentioned and figured by him is $V$. voigtii, described from a specimen in the Copenhagen Museum. Locality unknown. It differs from Semper's drawing of this species in being narrower as compared with its length, and in the sole of the foot. Semper's drawing is life-size, and could not fail to show the transverse ridges. As I have never yet dissected any species of this genus, I hesitate to begin upon a single valuable specimen until I have had some practice on well-known forms.

\section{Genus CycLophorus.}

5. Cyclophorus (Cýclohelix) nicobaricus, Behn (p. 444).

This species is distinct from C. crocatus or turbo, and is at once distinguished by the very sinuate and oblique form of the 
columellar side of the aperture, which has almost a tooth on it. Nevill records it from Koudul and Galathea Bay (Stoliczlca).

6. Cyclophorus moerchianus, de Roepstorff MS. (p. 444).

Car Nicobar, June 1881.

This shell was in Mr. de Roepstorff's collection, with a label written by Nevill, saying, "This is my no. 64, p. 275 of Handlist." I now consider it separable from C. charpentieri, and call it C. moerchianus, de R. MS. No. 64 of the 'Hand-list' is also found on Batte Malve (F. Stoliczka).

7. Cyclophorus perdix, Broderip and Sowerby (p. 444). list.

No. 7. Cyclophorus perdix, var. roepstorffiana, Nevill MS., Hand-

"Alt. $15 \cdot 5$, diam. $21.5 \mathrm{~mm}$. Distinguished from C. zollingeri, Mousson, by the less dilated last whorl and smaller aperture, keel more developed, and coloration of base different. Great Nicobar (type var. coll. F. A. de Roepstorff)."

To $C$. perdix Von Martens (Moll. Ost-Asien, p. 136) joins C. zollingeri (Sunda Strait and Banka) and C. porphyreticus, Benson, from Penang. I find one young shell of this species among Mr. de Roepstorff's shells, and I have three others, also immature, sent to me by my brother from the Nicobars.

\section{Genus Leptopoma.}

\section{Leptopoma immaculatum, Chemn. (p. 444).}

Nevill, in his MS. Hand-list, writes : "The L. vitreum, Lesson, is scarcely separable from $L$. immaculatum, especially var. latilabre, Mart. (Ceram), of the former, which Pfeiffer indeed considered a form of the latter. Mörch has correctly identified the type of Chemnitz's species as the Nicobar form. The Philippine form is certainly distinct; it must take the name of $L$.lave, as it is undoubtedly the form so-called by Wood and Reeve."

\section{Leptopoma roepstorffiandi (Nev.) (p. 444).}

This species is described in Nevill's 'Hand-list.' Var. gigantea, from the Andamans, and var. albida are given in his MS. copy.

1. Lagocheilus wüllerstorfianus, Pfeiffer and Zelebor (p. 444).

The operculum in this species is very thin, horny, slightly concave, and multispiral, flat in front.

In young specimens the surface is very rough, the spiral rib on the periphery finely hirsute, and the fine transverse striation in high relief; in this state the flame-like bands of colour are not visible, they are only seen in the weathered shells.

3. Lagocheilus roepstorffi, Mörch (p. 444).

Under this head Nevill, in his MS. Catalogue, gives var. cocoensis, from the Great Coco Island, collected by Ferd. Stoliczka. 
The type is in the Indian Museum, Calcutta, so I have not seen it. Nevill gives polynema, Mörch, from Teressa, collected by de Roepstorff, which is no. 10 of the 'Hand-list,' and no. 13 from Batte Malve, collected by Stoliczka, as a variety of polynema.

\section{Genus Lagocheilus.}

8. Lagocheilud tignarius, Bs. (Cyathopoma?, Benson) (p. 444).

The operculum in this species is slightly concave in front, multispiral; the spiral defined by a narrow rib in relief. The operculum of L. tomotrema, of the Khási Hill ranges, is horny, quite smooth in front, the spiral formation being but scarcely apparent.

\section{AcMella.}

Under this genus Nevill records $A$. andamanica as being in the Calcutta Museum, and says: "compared with A. hyalina (Theob. and Stolicz. from Moulmein), of which it is probably a large variety."

\section{Acmella mellilla (p. 444).}

Locality. South Andaman (de Roepstorff).

Shell dextral, ovately turreted; sculpture oblique, fine, close costulation; colour pale umber; spire depressedly conic; apex very blunt, suture impressed; whorls 5, sides flat; aperture oval, suboblique; peristome double, with a strong callus on the bodywhorl.

\section{Fig. C.}
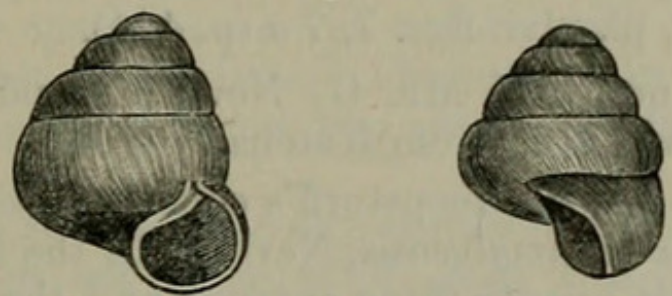

Acmella mellilla.

Size: maj. diam. $1 \cdot 25$; alt. axis $1 \cdot 75 \mathrm{~mm}$.

Only one specimen in the collection.

\section{Acmelda gibboidea, Nevill MS. (p. 444).}

The two typical examples of this species are in the Indian Museum, collected by de Roepstorff in the Andamans.

\section{Genus Crathopoma.}

1. Cyathopoma natalicium, n. sp. (p. 444).

Locality. Camorta.

This is no. 50 of Nevill's 'Hand-list,' which is not named. There are four specimens in the Indian Museum, 
Shell dextral, depressedly turbinate; openly umbilicated, flat below, angulate at the umbilicus; sculpture smooth above, with very fine regular transverse costulation on the last whorl, with a strong lirate rib on the periphery; colour pale ochraceous; spire low; apex blunt; suture well marked; whorls $4 \frac{1}{2}$, convex ; aperture arcuately circular, subvertical, sinuate on outer margin, somewhat angular below at the peripheral ribs ; peristome doublecontinuous.

Fig. D.
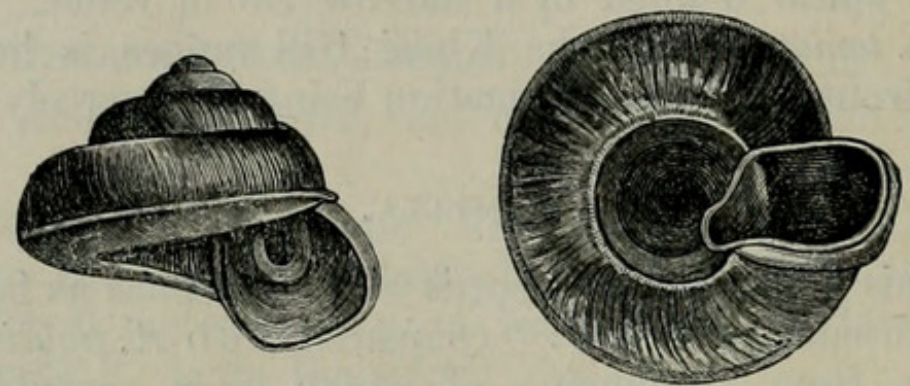

Cyathopoma natalicium. $\times 12$.

Size : maj. diam. $2 \cdot 25$; alt. axis $1.2 \mathrm{~mm}$.

Operculum multispiral, elongate, with a deep central depression. This appears, from the number of specimens in the tube, to be an abundant species. It is a very pretty distinct form.

\section{Genus Diplommatina.}

1. Diplommatina nicobarica, G.-A. Land and Freshwater Moll. Ind. p. 185, pl. xlvi. figs. 7, $7 a$ (p. 444).

This species is no. 13 of Mr. G. Nevill's Hand-list (p. 284)= roepstorffiana, Nevill MS., from Katchall (de $R$.).

This species in Mr. de Roepstorff's collection bears the name of D. carneola, Stol.=battimalyensis, Nevill. In the amended 'Handlist' I find the title roepstorffiana entered and the typical locality Katchall, with 3 specimens from Camorta and 20 from Batte Malve, collected by F. Stoliczka. It is somewhat similar to $D$. carneola from Moulmein, but it is more elongate and the costulation far closer and finer.

2. Diplommatina nicobarica, var. battemalvensis, n. $\mathrm{sp}$., Nevill MS. (p. 444).

I have discovered among some shells put up by Mr. G. Nevill two specimens in a tube, labelled as above, from the island of Batte Malve; they agree in all characters with the last species, but are much larger and more tumid, the antepenultimate whorl being much larger than in nicobarica.

Size: maj. diam. $1 \cdot 3$; alt. axis $3 \cdot 0$; body-whorl $0.9 \mathrm{~mm}$. 


\section{Genus Alycøus.}

\section{Alyceus reinhardti, Mörch (p. 445).}

The type of this species is from Great Nicobar Island and is larger than the species from Camorta, named by Mörch var. minor, only averaging $4 \mathrm{~mm}$. in diameter. The latter differs also in the form of the aperture, which is more circular and simple, the external peristome not being expanded and inflected, particularly below.

The form from Katchall is nearly as large and like that from the Great Nicobar.

3. Alycxus bUsbyi, G.-A. (p. 445).

This species was described in the Society's 'Proceedings' for 1893 , p. 595.

\section{Genus OMphaLotropis.}

6. Omphalotropis (Realia) brevis, n. sp. (p. 445).

Locality. Camorta, Nicobars (de Roepstorff).

Shell dextral, elongately turbinate, rimate; sculpture smooth, covered with a fine epidermis, having a few indistinct lines of growth; colour pale yellowish horny; spire conical, sides flat; apex sharp; suture impressed; whorls 6 , the last slightly carinate with a hair-like keel, which is seen in the whorl above; below a hairlike keel round the umbilical region; aperture ovate; peristome thin, not complete in specimen.

Size : maj. diam. 1.8 ; alt. axis $2.8 \mathrm{~mm}$.

Animal. One specimen was in a tube with a label by Nevill: " beats me, please send others." Camorta. In sorting out tubes full of mixed species I found two others inside two examples of Microcystina.

It is so much smaller than any species of this genus from these islands, although not quite adult, that I have no hesitation in naming it.

\section{Genus Pupina.}

\section{Pupina nicobarica (p. 445).}

Under this name Nevill gives two varieties in his MS. Catalogue: var. nana, long. $4 \cdot 6$, alt. $2 \cdot 5 \mathrm{~mm}$., Great Nicobar, and var. evertata, from de Roepstorff, from the same island.

As I have pointed out in the "Land and Freshwater Mollusca of India,' p. 45 (1882), the genus Sagdinewa of Mörch will not stand; his S. didrichsenii turns out to be an operculated form. There are some 20 specimens in Mr. de Roepstorff's collection, in seven of which I detected the operculum. This is multispiral, of about 4 whorls, and very thin; further examination showed that the shells were young Pupince; the operculum also corresponded. In some shells of Pupina nicobarica and in the white variety albina 
distinct transverse fine ribbing is seen, and on breaking a mature shell back to the same number of whorls as in so-called Sagdinella a precisely similar form of shell was presented. Moreover, this Pupina, at the commencement of the fifth whorl, contracts very considerably and the shell is perforate at this stage. On turning to the original description I see that Professor Mörch described it from a single example, and I can quite understand his being misled by this peculiar young form, so very unlike the typical mature shell in Pupina. I note that in this white very thin variety every gradation can be seen from shells quite glassy to others most distinctly ribbed. The drawing of Sagdinella didrichseni given on plate ix. figs. 1, 1 a, in my ' Land and Freshwater Mollusca of India,' was made from the type specimen sent to me from the Copenhagen Museum.

\section{Helicina.}

Nevill gives many varieties and subvarieties of the species of this genus, particularly of $H$. andamanica and $H$. scrupulum; he records that the animal of $H$. andamanica from Mount Harriet; Port Blair, "is of a mottled dark grey colour, sparsely dotted with sand-like specks, base of the tentacles yellow."

List of Genera and number of Species.

Helicacea.

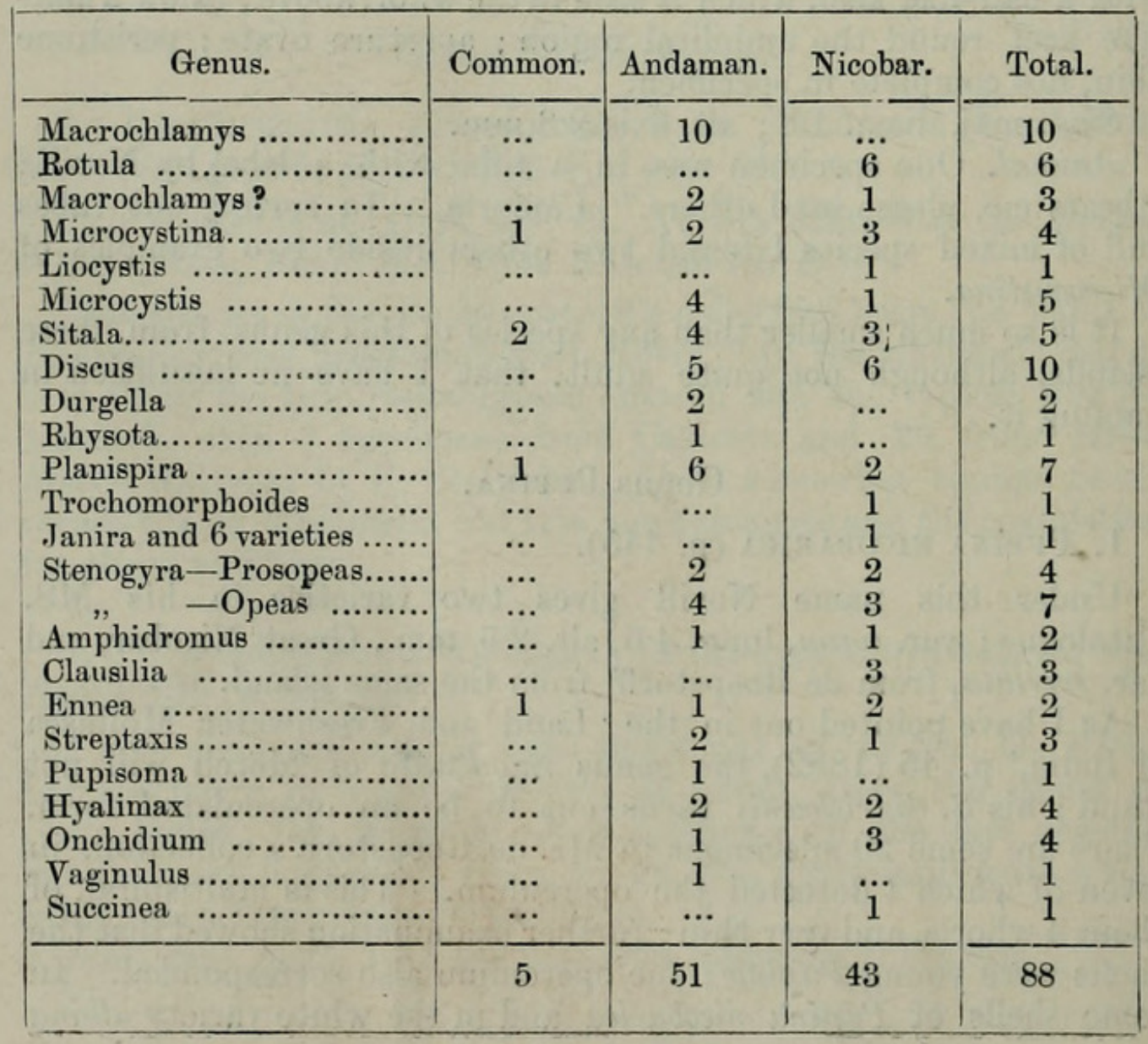


ol

UAAL HISI 


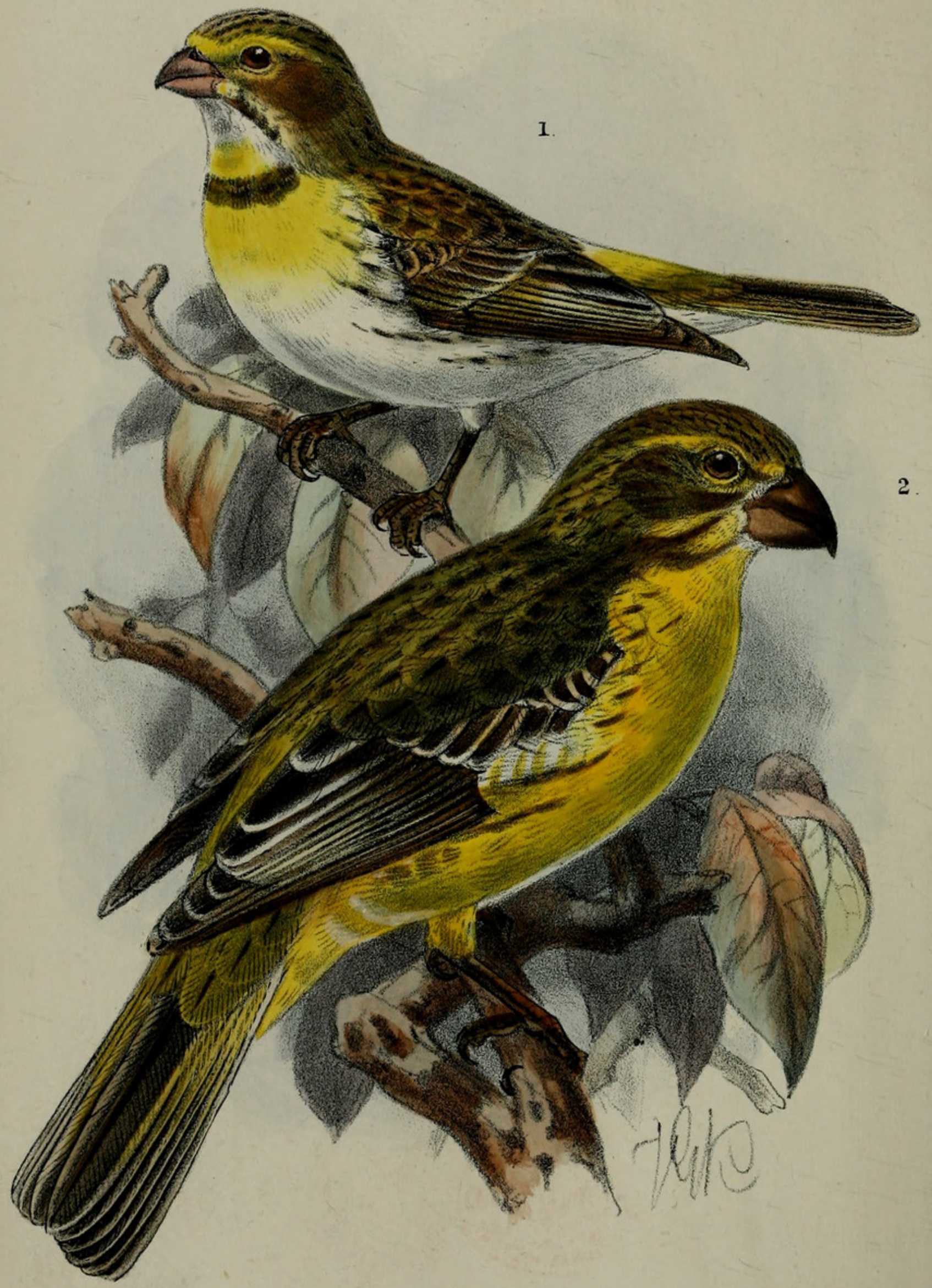

J.G.Keulemans del et lith

$$
\begin{aligned}
& \text { 1. SERINUS MACULICOLLIS } \\
& \text { 2. } m
\end{aligned}
$$


THAL HISI 
P. Z. S.1895 Pl. XXVIII.

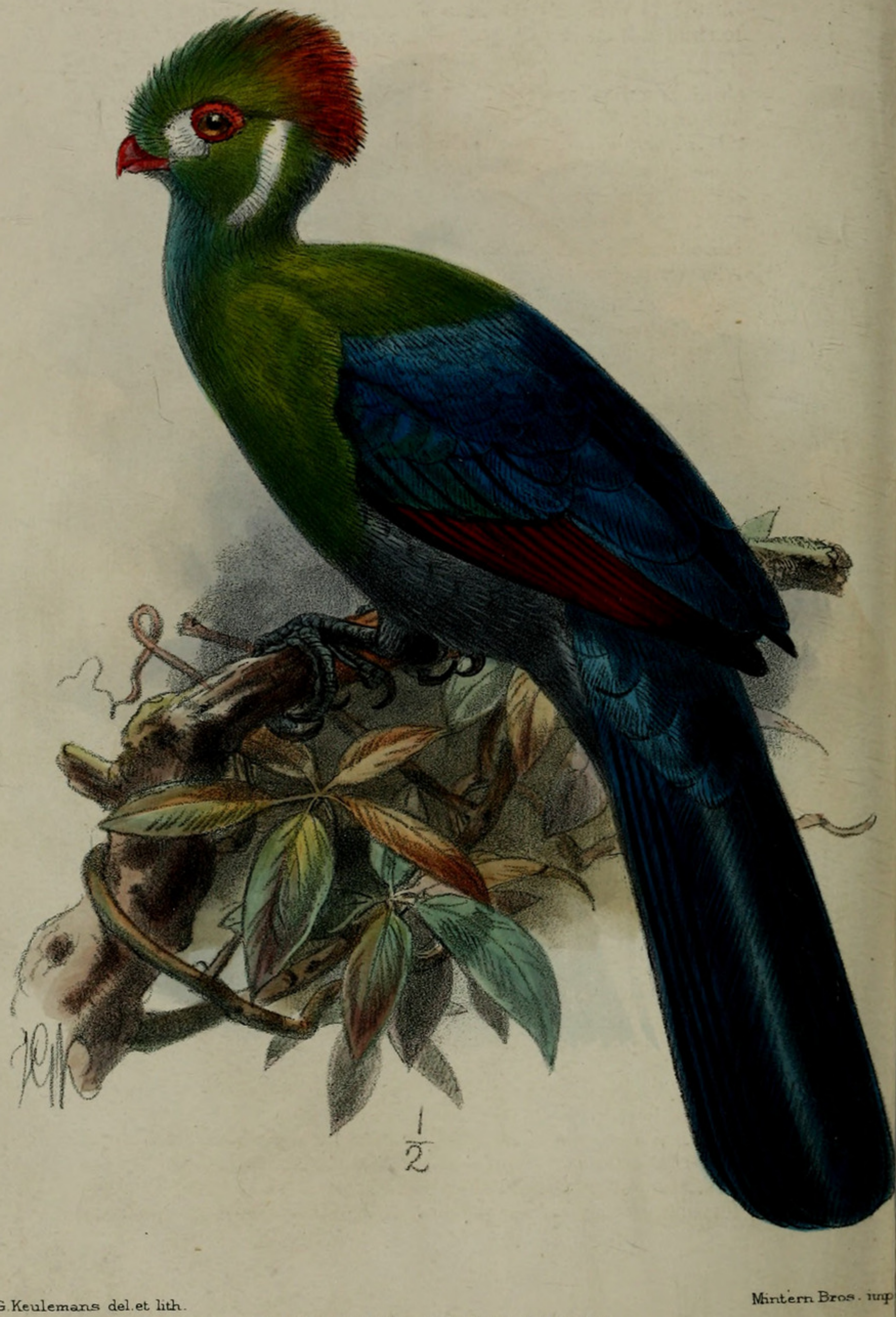


Cyctophoride.

\begin{tabular}{|c|c|c|c|c|}
\hline Genus. & Common. & Andaman & Nicobar. & Total. \\
\hline Cyclophorus (Cyclohelix) & & 2 & 5 & 7 \\
\hline 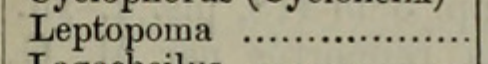 & .. & 4 & 2 & 6 \\
\hline Lagocheilus .... & ... & 3 & 5 & 8 \\
\hline Acmella ....................... & ... & 3 & 2 & 5 \\
\hline 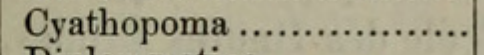 & ... & $\cdots$ & 1 & 1 \\
\hline Diplommatina ............. & $\cdots$ & & 2 & 2 \\
\hline Alycæus.. & & 1 & 2 & 3 \\
\hline 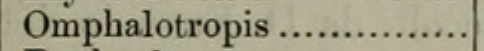 & ... & 4 & 3 & 7 \\
\hline Raphaulus........................ & $\cdots$ & ... & 1 & 1 \\
\hline Pupina ............... & ... & & 1 & 1 \\
\hline 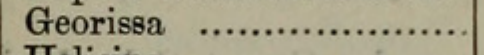 & & 1 & & 1 \\
\hline Helicina ........................ & 2 & 4 & 4 & 6 \\
\hline Truncatella ........................ & 1 & 1 & 1 & 1 \\
\hline Helicacea brought forward & $\begin{array}{l}3 \\
5\end{array}$ & 23 & 29 & $\begin{array}{l}49 \\
88\end{array}$ \\
\hline & & & & \\
\hline$T$ & 8 & 74 & 72 & 137 \\
\hline
\end{tabular}

7. On a Collection of Birds made by Dr. A. Donaldson Smith during his recent Expedition in Western Somaliland. By R. Bowdler Sharpe, LL.D., F.L.S., \&c.

[Received June 24, 1895.]

\section{(Plates XXVII. \& XXVIII.)}

The collection made by Dr. Donaldson Smith has proved to be of great importance, and some of his discoveries have been extremely interesting. The country through which he passed after leaving the Shebeli River has never been explored by a naturalist, and the result of Dr. Donaldson Smith's expedition has been to make us acquainted with quite a number of new species. The route taken has been described by the explorer in the 'Geographical Journal' for February of the present year (pp. 124-127), where a map of the country is given.

Starting from the Shebeli River, Dr. Smith marched in a northwesterly direction over gradually rising ground, till he reached an elevation of more than 5000 feet, and at Gineh, where he stayed for some time, the height is 6920 feet. In this neighbourhood and on the Darro Mountains (8000 feet) he obtained several of his most interesting birds, as also in the vicinity of Sheik Husein and Sheik Mahomed.

This exploration of Dr. Donaldson Smith's enables us to make a comparison of the avifauna of Western Somali-land with that of Abyssinia and Shoa and with that of the more southern regions of the Lake Country, and also of East Africa. I have therefore 
given references to Von Heuglin's work on the birds of Northeastern Africa, as well as to the following papers on the birds of Somali-land:-

G. E. Shelcex.- “ On Mr. E. Lort Phillips's collection of Birds from Somali Land.” Ibis, 1885, pp. 389-418, pls. x.-xii.

E. Oustaleet.- "Catalogue des Oiseaux rapportés par M. G. Révoil de son deuxième Voyage aux pays des Çomalis (Afrique Orientale).” Bibl. de l’École des Hautes Études, xxxi. art. no. 10, pp. 1-14 (1886).

T. SALVADORI.- "Uceelli del Somali raccolti da D. Eugenio dei Principe Ruspoli." Mem. R. Accad. Torino, (2) xliv. pp. 547-564.

I have also referred to the excellent papers by Count Salvadori on the birds of Shoa, and to the recently published 'Vögel Deutsch-Ost-Afrika's' of Dr. Reichenow.

For the sake of convenience, I have followed the order adopted in my papers on the collections made by Mr. F. J. Jackson (Ibis, 1891, pp. 233-260, 587-602 ; 1892, pp. 152-164, 229-322, 534$555)$, so as to render a comparison possible between the avifaunæ of the two districts. The present collection being the largest that has ever been made in Somali-land, I have taken the opportunity of giving in full the distribution of the species as stated by Heuglin, Salvadori, and Reichenow, so that we can now draw some conclusions as to the relations of the avifauna of Somaliland with that of the surrounding countries, which it has not been possible to do before.

The localities of the specimens are mostly to be found in Dr. Smith's map ; but for the identification of those not mentioned there I have been indebted to the kindness of Mr. F. Gillett, who accompanied Dr. Smith on his expedition, but who had to return to England from the Shebeli on receipt of the news of his father's death. He brought the collections made up to the date of the return of the expedition to the Webi-Shebeli safely to the coast, and he has given me the names of the different camping-places.

\section{Order PASSERES.}

\section{Fam. Corvide.}

\section{Corvulitur crassirostris.}

Archicorax crassirostris (Rüpp.); Heugl. Orn. N.O.-Afr. i.p. 507.

Corvultur crassirostris (Rüpp.); Sharpe, Cat. B. iii. p. 25 (1877); Salvad. Ann. Genov. (2) i. p. 205 (1884), vi. p. 302 (1886).

$a, b . \quad 0$ o ad. Sheik Husein, Sept. 22, 1894.

This large Raven is said by Heuglin to be an inhabitant of the mountains of Abyssinia, above 4000 feet, northwards to Hamasien, and eastwards to Qalabat and Takah, south to Shoa and the Somali plateaux, and thence, in the elevated districts, westwards from the Upper White Nile. Antinori found the species common 
in the mountains of Ankober in Shoa. In East Africa it is replaced by C. albicollis ( $c f$. Reichen. Vög. Deutsch-Ost-Afr. p. 166).

Fam. Sturnidx.

\section{Dilophus carunculatus.}

Dilophus carunculatus (Gm.) ; Heugl. Orn. N.O.-Afr. i. p. 529 ; Salvad. Ann. Mus. Genov. (2) i. p. 197 (1884), vi. p. 297 (1888); Sharpe, Cat. B. xiii. p. 61 (1890); id. Ibis, 1891, p. 243 ; Salvad. Mem. R. Accad. Torino, (2) xliv. p. 560 (1894); Reichen. Vög. Deutsch-Ost-Afr. p. 171 (1894).

a. ․ Hargeisa, July 16, 1894. Iris brown; bare skin lemon-yellow.

Heuglin was not certain whether this Starling is sedentary in N.E. Africa or not. It was rare, and found during the rainy season in Abyssinia, on the Blue and White Niles, and in Kordofan. In Shoa, however, Antinori found it in flocks throughout the year in the valley of Daimbi, breeding in May. Ragazzi records it from the Falls of Gherbá. Mr. Jackson met with the species in Kitosh, and says that it was very common all round Naivasha and north to Kisidong in large flocks. It is also distributed widely in German East Africa, Dr. Reichenow giving the following localities for the species :-Igónda, Ugálla, Irángi, Wembaere Steppes, Simiu River, Ampeke, Ikuni Island.

\section{Family EuLabetidx.}

\section{LAMPROTORNIS PORPHYROPTERUS.}

Lamprotornis purpuroptera, Rüpp. Syst. Uebers. pp. 64, 75, Taf. xxv. (1845); Salvad. Ann. Mus. Genov. (2) i. p. 198 (1884).

Lamprotornis porphyroptera (Cab.), Heugl. Orn. N.O.-Afr. i. p. 511; Sharpe, Cat. B. Brit. Mus. xiii. p. 156 (1890); id. Ibis, 1891, p. 240 ; Reichen. Vög. Deutsch-Ost-Afr. p. 173 (1894).

a. $\delta$. Sheik Husein, Oct. 1, 1894. Iris cream-colour.

According to Heuglin a tolerably common bird in the mountains of Northern Abyssinia up to 6000 feet and the western "Quola" district, in Senar, Kordofan, Takah, and along the White Nile and its tributaries. It is sedentary, breeding in July and August. In Shoa, Antinori says it is plentiful in the " Kolla" districts, but was rare near Daimbi. Mr. Jackson found the species plentiful in small flocks in Turquel; and, according to Dr. Reichenow, it is found on the Pangani and Ugálla Rivers, and his other localities are Bukomé Itále, Kagéyi, and the Simiu River, while it has likewise been found at Witu, Lamo, and in Wapokomoland, and at Nassa on the Victoria Nyanza.

\section{Cosmopsarus Regius.}

Cosmopsarus regius, Shelley, Ibis, 1885, p. 411; Sharpe, Cat. B. Brit. Mus. xiii. p. 160 (1890); id. Ibis, 1891, p. 241 Salvad, 
Mem. R. Accad. Torino, (2) xliv. p. 559 (1894: Webbe River, Webbe Schebeli, Hento Valley, Banan); Reichen. Vög. DeutschOst-Afr. p. 173 (1894).

a. ot ad. Milmil, July 26, 1894.

b. $\sigma^{\star}$ ad. Hargeisa, July 21, 1894. Iris white.

c. $\delta$ ad. Jadid-hurrieh, Jan. 7, 1895. Iris white.

Somali-land seems to be the metropolis of this beautiful species ; but it has been found to the south at Pare by Dr. Fischer, and in the "wilderness" near the River Tsavo (not "Tskro," as printed in my paper !) by Mr. Jackson. Here it was plentiful.

\section{Galeopsar salvadorit.}

Galeopsar salvadorii, Sharpe, Ibis, 1891, p. 241, pl. iv.

$a, b$. of ㅇ․ Stonybrook, Ehrer River, August 18, 1894.

There appears to be no difference in the colouring of the sexes.

This species was discovered by Mr. F. J. Jackson in Turquel, and Dr. Smith found it in the mountainous country on the Ehrer River, near its junction with the Shebeli. I have also received a specimen from Mr. Neumann obtained between Mt. Kenia and Lake Rudolph.

\section{AMYYRRUS MORIO.}

Amydrus morio (L.); Sharpe, Cat. B. Brit. Mus. xiii. p. 161 (1890) ; id. Ibis, 1891, p. 242 ; Reichen. Vög. Deutsch-Ost-Afr. p. 172 (1894).

Amydrus rueppelli, Verr.; Heugl. Orn. N.O.-Afr. i. p. 524; Salvad. Ann. Mus. Genov. (2) i. p. 201 (1884), vi. p. 299 (1888).

a. ․ Sheik Mahomed, Nov. 13, 1894. Iris bright red; bill and feet black.

In N.E. Africa, Heuglin considered this species not to be sedentary. He found it in rocky valleys with high trees in Abyssinia, northwards to Barka, in Fazogl, and Southern Kordofan, but only during the rainy season. In Shoa, Antinori states that the speciesis common on the elevated "Kolla" at a moderate height. Mr. Jackson met with it on Mount Elgon, at Turquel, and also in the Ulu country in Ukambani. Dr. Reichenow records the species from Ugógo, Nguru, Kilima-njaro, Lake Tanganyika, and Bussisi.

\section{Lamprocolius chaLyBeUs.}

Lamprocolius chalybeus (Ehr.); Heugl. Orn. N.O.-Afr.i. p. 514; Salvad. Ann. Mus. Genov. (2) i. p. 199 (1884), vi. p. 297 (1888); Sharpe, Cat. B. Brit. Mus. xiii. p. 176 (1890); id. Ibis, 1891, p. 242 ; Salvad. Mem. R. Accad. Torino, (2) xliv. p. 559 (1894: Hento Valley).

a. đ. Dabulli, Sept. 16, 1894. Iris orange.

b. ㅇ. Goura, Sept. 14, 1894. Iris golden yellow.

One of the commonest and most widely distributed birds in N.E. Africa. In the Nile district and the Bischarin Steppes it 
extends northwards to $20^{\circ} \mathrm{N}$. lat. It reaches also the coast of Samhar, and is found over the whole of Abyssinia up to 8000 or 9000 feet, in the Gala countries, in Senaar and Kordofan, as well as in the district of the Lower Nile. In Shoa, Antinori found the species breeding. Mr. Jackson met with it near Lake Naiwascha, but in East Africa generally its place seems to be taken by L. sycobius, Peters ( $c f$. Reichen. Vög. Deutsch-Ost-Afr. p. 172).

\section{Heteropsar albicapillus.}

Notauges albicapillus (Blyth); Heugl. Orn., N.O.-Afr. i. p. 520 (1871); Shelley, Ibis, 1885, p. 413; Oust. Bibl. Ecole Hautes Etudes, xxxi. art. 10, p. 11 (1886).

Heteropsar albicapillus, Sharpe, Cat. B. Brit. Mus. xxxi. p. 186 (1890) ; Salvad. t. c. p. 559 (1894: Warandab).

a. Ad. Lessabane, 3150 feet. Breeding.

9. Spreo shelleyi.

Spreo shelleyi, Sharpe, Cat. B. Brit. Mus. xiii. p. 190 (1890).

a. o. Hargeisa, July 21, 1894. Iris orange.

b. ㅇ. Darar, Sept. 15, 1894. Iris orange next the pupil, merging into lemon-yellow.

10. SpReo SUPERBUS.

Notanges superbus (Rüpp.); Heugl. Orn. N.O.-Afr. i. p. 517 (1871); Shelley, Ibis, 1885, p. 412 ; Oust. Bibl. École Hautes Êtudes, xxxi. art. 10, p. 11 (1886); Salvad. Ann. Mus. Genov. (2) i. p. 199 (1884), vi. p. 298 (1888); id. Mem. R. Accad. Torino, (2) xliv. p. 560 (1894: Warandab and Mandera).

Spreo superbus, Sharpe, Cat. B. Brit. Mus. xiii. p. 189 (1890); id. Ibis, 1891, p. 243; Reichen. Vög. Deutsch-Ost-Afr. p. 171 (1894).

a. $\delta$ ad. Dunarn, Jan. 4, 1895. Iris cream-colour.

Heuglin states that this Starling is found on the Somali plateaux, on the highlands of Shoa, on the Bahr-el-Abiad, and the upper Djur. On the White Nile it never extends north of $7^{\circ}$ or $8^{\circ} \mathrm{N}$. lat. Brehm's statement that the species is found up to $10^{\circ}$ N. lat. is wrong, according to Heuglin, who says that it is met with first to the south of the swamp-region. Ragazzi met with it in Shoa at Cialalakà, and Antinori says that it is very common in the spacious valley of Daimbi, where it is resident. Mr. Jackson met with it at Machako's in Ukambani, and Dr. Reichenow gives many localities in German East-Africa, from Dar-es-Salaam through Masai-land.

\section{Fam. Buphagidx.}

\section{Buphaga ERYTHRorhyNCHA.}

- Buphaga erythrorhyncha (Stanl.); Heugl. Orn. N.O.-Afr. i. p. 716 (1891); Shelley, Ibis, 1885, p. 410; Salvad. Ann. Mus. 
Genov. (2) i. p. 196 (1884), vi. p. 297 (1888); Sharpe, Cat. B. Brit. Mus. xiii. p. 196 (1890); id. Ibis, 1891, p. 243; Salvad. Mem. R. Accad. Torino, (2) xliv. p. 561 (1894: Warandab); Reichen. Vög. Deutsch-Ost-Afr. p. 170 (1894).

$a, b$. $q$. Widdarwiddo, Dec. 4, 1894. Iris orange; bill vermilion; eyelids bright yellow.

In North-eastern Africa, according to Heuglin, this species is commoner than $B$. africana. It is found in the coast-districts of Abyssinia down to Somali-land, in the low-lying hot districts of Abyssinia up to 6000 feet, further west on the Upper Blue and White Niles, and apparently also in the mountains to the south of Kordofan. In Shoa it is common, according to Antinori, and Ragazzi also records it as very plentiful. Dr. Reichenow gives a very general distribution for the species in East Africa-Usegúha, Ugógo, Aruscha, Sigirari, Ugálla, Kakoma, Kawendi. Mr. Jackson also procured it in Ukambani, and again in Kitosh.

\section{Fam. DicruRIDe.}

\section{Buchanga assimmis.}

Dicrourus divaricatus (Licht.); Heugl. Orn. N.O.-Afr. i. p. 422 (1871).

Buchanga assimitis (Bechst.); Sharpe, Cat. B. Brit. Mus. iii. p. 247 (1877); Shelley, Ibis, 1885, p. 410; Salvad. Mem. R. Accad. Torino, (2) xliv. p. 555 (1894).

Dicrurus afer (Licht.); Reichen. Vög. Deutsch-Ost-Afr. p. 166 (1894).

Musicus assimilis, Salvad. Orn. Mus. Genov. (2) i. p. 113 (1884), vi. p. 239 (1888).

a. $q$ ad. Sibbe, Aug. 3, 1894 . Iris red.

This species is found commonly, both singly and in pairs, in North-eastern Africa, but only south of the line of rainfall $\left(20^{\circ}\right.$ N. lat.), the hot coast-lands of Abyssinia to the districts of the Danakil and Somali people, up to the heights of the Abyssinian mountains, in Senar, Takah, Southern Nubia, Kordofan, and the White Nile districts, according to Heuglin. It has a wide distribution throughout Eastern Africa. In Shoa, Antinori says it is a common species in the mimosa bushes, in the low "Kolla," and on the plains, as well as along the rivers and marsh-lands.

\section{Fam. OrIoLide.}

\section{Oriolus larvatus.}

Oriolus larvatus, Licht.; Heugl. Orn. N.O.-Afr. i. p. 403 (1869); Sharpe, Cat. B. Brit. Mus. iii. p. 217 (1877); id. Ibis, 1891, p. 243.

Oriolus rolleti, Reichen. Vög. Deutsch-Ost-Afr. p. 168 (1894).

a. $\delta$ ad. Darar, Sept. 15, 1894. Bill light brown; feet grey; iris carmine. 
In Shoa the place of this species is taken by Oriolus monachus. 0 . rolleti is a small race, which does not seem to me to be specifically distinct from 0 .larvatus; but it is this form which occurs in Somali-land, and is recorded by Dr. Reichenow from numerous localities throughout Eastern Africa. Mr. Jackson met with the species at Turquel in the Suk country and on Mount Elgon.

O. rolleti is said by Heuglin to be found on the Upper White Nile. On the Belenia Mountains it is not rare, but does not extend north of $8^{\circ} \mathrm{N}$. lat.

\section{Fam. Ploceide.}

\section{VIDUA PRINCIPALIS.}

Vidua principalis, Heugl., Orn. N.O.-Afr. i. p. 585 (1871); Oust. Bibl. École Hautes Etudes, xxxi. art. 10, p. 10 (1886); Sharpe, Cat. B. Brit. Mus. xiii. p. 203 (1890); id. Ibis, 1891, p. 244.

Vidua erythrorhyncha (Sw.); Salvad. Ann. Mus. Genov. (2) i. p. 181 (1884), vi. p. 285 (1888).

Vidua serena (L.) ; Reichen. Vög. Deutsch-Ost-Afr. p. 193 (1894).

a. $\delta$ hiem. Sheik Husein, Oct. 30, 1894. Iris dark brown; bill vermilion.

Heuglin was not certain whether this little Weaver-bird was resident in North-eastern Africa. Its northern limit seems to be between $16^{\circ}$ and $17^{\circ} \mathrm{N}$. lat., and from here it occurs southwards on the coast and in the interior of Abyssinia, but not beyond 6000-7000 feet in Takah, Senar, Kordofan, and the region of the White Nile. In Shoa, Antinori says that the species arrives in May and remains till September. Dr. Ragazzi met with individuals in March, May, and June. Mr. Jackson only obtained the species at Nzoni in February, but it is very widely spread over East Africa, from the coast up to the Victoria Nyanza.

\section{LINURA FISCHERI.}

Linura fischeri, Reichen.; Salvad. Ann. Mus. Gen. (2) vi. p. 104 (1888) ; id. Mem. R. Accad. Torino, (2) xliv. p. 557 (1894: S. of desert of Ogaden); Reichen. Vög. Deutsch-Ost-Afr. p. 192 (1894); Sharpe, Cat. B. Brit. Mus. xiii. p. 210 (1890).

Vidua (Linura) fischeri, Oust. Bibl. Ecole Hautes Études, xxxi. art. 10 (1886).

a. o . Goura, Sept. 14, 1894. Iris dark brown; feet salmoncolour; bill dull vermilion.

b. o. Bussarler, Nov. 28, 1894. Iris brown; bill and feet salmon-colour.

Somali-land must be one of the northern limits of the range of this species. It was procured by Dr. Ragazzi at Soddè in Shoa in August. Dr. Reichenow records it from Usegúha and the plains south of Kilima-njaro. 


\section{Steganura Paradisea.}

Vidua paradisea orientalis, Heugl. Orn. N.O.-Afr. i. p. 583 (1869).

Vidua verreauxi, Heugl. Orn. N.O.-Afr. iv. p. cxxxiv (1874); Salvad. Ann. Mus. Genov. (2) vi. p. 286 (1888).

Steganura paradisea (L.) ; Sharpe, Cat. B. Brit. Mus. xiii. p. 211 (1890) ; Reichen. Vög. Deutsch-Ost-Afr. p. 192 (1894).

Vidua paradisea, Oust. Bibl. École Hautes Etudes, xxxi. art. 10, p. 10 (1886).

$a, b$. o ad. Smith River, Sept. 11, 1894. Iris dark brown. Breeding.

c. $\delta$ ad.; $d$. $\delta$ juv. Darro Mountains, Nov. 20, 1894. Iris and feet brown.

Heuglin doubts whether this is a resident species in North-east Africa, as he only observed it between the months of May and December. It does not extend beyond $17^{\circ} \mathrm{N}$. lat., but reaches a height of 6000-7000 feet in Abyssinia. It is common in Bogos, Abyssinia, Senar, Kordofan, and the whole district of the White Nile. In Shoa it seems to be rare, as Antinori did not procure specimens, and Dr. Ragazzi only got one at Ambokarra in May. Dr. Reichenow gives its distribution in German East Africa as extending from Dar-es-Salaam up to the Victoria Nyanza, his list of localities being too large to quote.

\section{Pyromelana franciscana.}

Enplectes franciscanus (Isert); Heugl. Orn. N.O.-Afr. i. p. 571 (1871); Salvad. Ann. Mus. Gen. (2) i. p. 184, vi. p. 288 (1888).

Pyromelana franciscana, Shelley, Ibis, 1885, p. 409 ; Oust. Bibl. Écoles Hautes Études, xxxi. art. 10, p. 10 (1886); Sharpe, Cat. B. Brit. Mus. xiii. p. 233 (1890); id. Ibis, 1891, p. 248.

A migrant in North-eastern Africa, according to Heuglin, arriving from the interior in June and July. It is especially common in the lowlands of Abyssinia, extending to 1000 feet; as well as in Takah, Senar, Kordofan, and Nubia. Its most northern limit on the Nile is $22^{\circ} \mathrm{N}$. lat. In Shoa, Antinori states that it arrives in May, and he procured specimens from May to September. Dr. Ragazzi also met with the species in Shoa from the end of April to August. Mr. Jackson procured a male at Elgeyo in July, but it is not included in Dr. Reichenow's list of the birds of German East Africa.

\section{Pyromelana xanthomelana.}

Euplectes capensis, var. minor, Heugl. Orn. N.O.-Afr. i. p. 573 (1871).

Pyromelana xanthomelana (Rüpp.); Sharpe, Cat. B. Brit. Mus. xiii. p. 239 (1890); id. Ibis, 1891, p. 248.

Euplectes xanthomelas, Salvad. Ann. Mus. Genov. (2)i. p. 186 (1884), vi. p. 109 (1888). 
Orynx xanthomelas, Reichen. Vög. Deutsch-Ost-Afr. p. 190 (1894).

a. $\delta$ imm. Budda, Nov. 4, 1894. Feet and iris brown.

Found by Rüppell in the provinces of Tembién and Semién in Abyssinia. Heuglin met with this species in the highlands of Wogara, up to 8000 to 10,000 feet. Antinori says that he found it in the country of the Kidj Negroes on the Upper White Nile, where Heuglin never observed it. From May to October Antinori found this Weaver-bird in Shoa, where it was common in the "Kolla" districts, and Ragazzi procured specimens from Antoto in December. Mr. Jackson met with it on Mount Elyon in December, and at Elgeyo in July; while Dr. Reichenow gives several places where the species has been procured in German East Africa.

\section{Phileterus cabanisi.}

Philaterus cabanisi (F. \& R.); Sharpe, Cat. B. Brit. Mus. xii. p. 251 (1890).

Nigrita cabanisi, Reichen. Vög. Deutsch-Ost-Afr, p. 184 (1894). $a, b, c . \delta$ ad.; $d$. $q$ ad. Dabulla, July 16 . Bill silvery white; feet brownish flesh-colour; iris orange.

This is a considerable extension of the northward range of this Wearer-bird, which was only known before from the Masai country.

\section{Quelea ethiopica.}

Hyphantica athiopica (Sund.); Heugl. Orn. N.O.-Afr. p. 543 (1871).

Quelea cethiopica, Salvad. Ann. Mus. Gen. (2) i. p. 193 (1884), vi. p. 293 (1888); Sharpe, Cat. B. Brit. Mus. xiii. p. 259 (1890); id. Ibis, 1891, p. 250.

Ploceus sanguinirostris, var. athiopicus, Oust. Bibl. École Hautes Études, xxxi. art. 10, p. 10 (1886).

a. $\delta ; b$. ․ Shebeli River, Aug. 28, 1894. Iris reddish brown; bill red; feet dark flesh-colour; eyelids rawsienna. In the female the iris was brown.

c. $ᄋ$ ad. Sillul, Aug. 6, 1874. Bill pale carmine; feet fleshcolour; iris light brown; eyelid yellow-ochre.

d. + ad. Sillul, Aug. 6, 1894. Bill and eyelids pale yellow ; feet flesh-colour; iris light brown.

The way in which the black varies in extent on the lores in this series makes me very doubtful of the validity of $Q$. intermedia.

According to Heuglin, this species is a migrant in Kordofan, Senar, Southern Nubia, and Takah with the first summer rains. It inhabits the mountains, up to 6000 feet, as far east as Bogosland. It goes southwards in September and October, and he met with numbers of this bird in the White Nile district in January.

Proc. Zool. Soc. -1895 , No. XXX. 
In November and April, Antinori saw the species in Shoa, at Diambi and Lake Cialalakà, and Dr. Ragazzi procured it at Soddè in August. Mr. Jackson appears to have shot specimens only in the Teita district, and Dr. Reichenow gives the following localities for Q. intermedia:-Pangani, Usegùha, Ugogo, Parè Mountains, Nguruman, Kageije, Igonda.

\section{Amadina fasciata.}

Sporothlastes fasciatus (Gm.) ; Heugl. Orn. N.O.-Afr. i. p. 596 (1871).

Amadina fasciata (Gm.) ; Salvad. Ann. Mus. Gen. (2) i. p. 179 (1884), vi. p. 28:3 (1888) ; Sharpe, Cat. B. Brit. Mus. xiii. p. 289 (1890); Reichen. Vög. Deutsch-Ost-Afr. p. 183 (1894).

a. $\delta$ ad. Lammo, Aug. 12, 1894 . Breeding.

$b, c$. $\delta$ q ad. Goura, Sept. 14, 1894. Bill grey; feet fleshcolour; iris reddish brown.

Inhabits the Abyssinian coast-lands northwards to $17^{\circ} \mathrm{N}$. lat., Kordofan, and many localities in the White Nile district; and Heuglin observed it during and after the rainy season up to December. Antinori found the species in the country of the Req Negroes. The last-named naturalist also met with it in Shoa in May, and again in November and December, and Dr. Ragazzi found it near Tofan in August, in great flocks. It extends also into German East Africa, as Dr. Reichenow records it from Usegùha, Nguruman, and the Wembaere Steppes.

\section{Ademosyne cantans.}

Uroloncha cantans (Gm.); Heugl. Orn. N.O.-Afr. i. p. 594 (1871).

Munia cantıns, Salvad. Ann. Mus. Genov. (2) vi. p. 284 (1888). Aidemosyne cantans, Sharpe, Cat. B. Brit. Mus. xiii. p. 371 (1890).

$a, b$. of 우 ad. Sillul, Aug. 6, 1894. Bill dark slate-colour; feet light slate-colour; iris dark brown.

c. $\delta$ ad. Sillul, Aug. 10.

Heuglin says that this species occurs in pairs or in small flocks, which are scattered, during the rainy season, from Dongola, southwards to Kordofan, Senar, Abyssinia, on the Lower White Nile, and on the coast of Somali-land. It breeds from August to October, and Vierthaler found a nest in January. Dr. Ragazzi once obtained it in Shoa at Soddè in August.

\section{Estrelda RHODOPYGa.}

Habropyga frenata (Licht. MSS.); Heugl. Orn. N.O.-Afr. i. p. 605 (1871).

Estrelda rhodopyga, Sund.; Salvad. Ann. Mus. Gen. (2) vi. p. 282 (1888); Sharpe, Cat. B. Brit. Mus. xiii. p. 396 (1890); Reichen. Vög. Deutsch-Ost-Afr. p. 187 (1894). 
a. $ᄋ$ ad. Webbe Shebeli, Aug. 28, 1894. Iris light brown.

b. Imm. Sheik Husein, Sept. 29, 1894. Iris dark brown; feet dark grey.

Heuglin says that he obtained a pair of this species near Keren in Bogos-land during the rainy season. Dr. Ragazzi met with it at Soddè in Shoa in August, and Dr. Reichenow records it from Bussisi.

\section{Estrelda nigrimentum.}

Estrelda nigrimentum, Salvad. Ann. Mus. Genov. (2) vi. p. 281 (1888); Sharpe, Cat. B. Brit. Mus. xiii. p. 399 (1890).

a. Ad. Bussarler, Nov. 28, 1894. Iris reddish brown; bill grey. This beautiful little Waxbill was discovered by Dr. Ragazzi at Farrè in Shoa, in February 1886.

\section{Estrelda PHENicotis.}

Urceginthus phonicotis (Sw.); Heugl. Orn. N.O.-Afr. i. p. 619 (1871); Salvad. Ann. Mus. Genov. (2) i. p. 177 (1884), vi. p. 279 (1888).

Estrelda phonicotis (Swains.); Sharpe, Cat. B. Brit. Mus. xiii. p. 400 (1890); id. Ibis, 1891, p. 251.

a. + ad. Luku, Sept. 17, 1894. Iris light brown; feet light brown; bill dark pink at the base, black at apex.

$b, c .0$ ad. Sheik Husein, Oct. $13,15,1894$. Iris red; bill dark pink, black at tip ; feet light brown. Caught on nest no. 12 .

Heuglin states that this species is found in Abyssinia up to 7000 feet in Takah, Senar, on the White Nile, and in Kordofan, nowhere plentifully and never in flocks, but generally singly or in pairs. It is a resident and breeds. In Shoa it is also common and stationary, according to Antinori, but here it is found in little flocks. His dates are between April and November, and Dr. Ragazzi procured the species in February and March. Mr. Jackson did not meet with it, nor is it recorded by Dr. Reichenow from German East Africa.

\section{Granatina ianthogastra.}

Urceginthus ianthinogaster, Shelley, Ibis, 1885, p. 408; Salvad. Ann. Mus. Genov. (2) vi. p. 279 (1888).

Granatina ianthogastra (Reichen.); Sharpe, Cat. B. Brit. Mus. xiii. p. 404 (1890); Reichen. Vög. Deutsch-Ost-Afr. p. 186 (1894).

a. $\delta$ ad. Milmil, July 26, 1894 . Iris and eyelid red.

b. o juv. Okoto, Sept. 7, 1894. Iris and eyelid light brown; bill pink; legs grey.

c. $\&$ ad. Sheik Husein, Sept. 24, 1894. Iris scarlet; bill vermilion.

d, e. $\delta$ ad. Sheik Husein, Sept. 29, 1894. Iris Indian red; bill and eyelids vermilion; legs grey. 
This is a Somali species, which extends its range southwards into East Africa, as Dr. Reichenow records it from the Konga River, Aruscha, Masai-land, and Ugogo. Dr. Ragazzi has also obtained it in Shoa at the Falls of Farrè, near Dinghai Mesghià, in March.

\section{HeterhyphaNtes EMINi.}

Sycobrotus emini, Hartl. Orn. Centralbl. 1882, p. 92.

Heterhyphantes emini, Sharpe, Cat. B. Brit. Mus. xiii. p. 420 (1890).

a. Imm. Sheik Mahomed, Nov. 7, 1894. Bill black; iris white; feet light brown.

It is interesting to find this Equatorial African species in Western Somali-land.

28. Hyphantornis galbula.

Hyphantornis galbula (Rüpp.); Heugl. Orn. N.O.-Afr. i. p. 557, tab. xviii. fig. D (1871); Salvad. Ann. Mus. Genov. (2) i. p. 191 (1884), vi. p. 291 (1888) ; Sharpe, Cat. B. Brit. Mus. xiii. p. 442 (1890).

$a, b . \delta$ ad. ; $c, d$. 우 ad. Boholgarshan, July 15, 1894.

Heuglin says that the range of this Weaver-bird is from $19^{\circ} \mathrm{N}$. lat. southwards to the district of the Eisa Somalis; it is most plentiful in Sambar and Bogos-land, from the sea-shore up to 6000 feet. In the interior of Abyssinia, the eastern districts of Tigrié, it appears much less frequently, as in the Nile region. On the Bischarin Mountains it extends to the neighbourhood of Suakin. In Shoa, Antinori procured specimens from March to August, and Dr. Ragazzi records the species as common and breeding near the Farrè Falls.

\section{Hyphantornis vitellina.}

Hyphantornis vitellina (Licht.); Heugl. Orn. N.O.-Afr. i. p. 555, tab. xviii. fig. C (1871); Sharpe, Cat. B. Brit. Mus. xiii. p. 462 (1890); id. Ibis, 1891, p. 254.

$a, b . \sigma^{\circ}$ ad. Darro Mountains, Sept. 15, 1894. Iris orange; feet light brown.

This Weaver-bird, according to Heuglin, appears at the end of May and June in the region of the Lower Blue and White Niles, and on the Nile itself north to Berber. It appears not to occur in Shoa, but was found by Mr. Jackson at Kamassia.

\section{Cinnamoptertix rubiginosa.}

Hyphantornis rubiginosa (Rüpp.); Heugl. Orn. N.O.-Afr. i. p. $560(1871)$.

Cinnamopteryx rubiginosa (Rüpp.); Sharpe, Cat. B. Brit. Mus. xiii. p. $473(1890)$; id. Ibis, 1891, p. 254.

Ploceus rubiginosus, Reichen. Vög. Deutsch-Ost-Afr. p. 180 (1895). 
a. $\delta$ ad. Darar, Sept. 15, 1894. Iris reddish brown; feet and toes grey.

Found by Rüppell in the warmer valleys in Abyssinia, but appears to be local, and apparently migratory. Heuglin himself never met with the species, but Mr. Jackson procured it near Lake Baringo, and Dr. Reichenow records it from Ugogo and Igonda.

\section{Dinemellia dinemelli.}

Textor dinemelli (Rüpp. ex Horsf. MSS.); Heugl. Orn. N.O.Afr. i. p. 534 (1871); Salvad. Ann. Mus. Genov. (2) i. p. 194 (1884) ; Shelley, Ibis, 1885, p. 410.

Dinemellia dinemelli (Rüpp.), Sharpe, Cat. B. Brit. Mus. xiii. p. 506 (1890); id. Ibis, 1891, p. 255; Salvad. Mem. R. Accad. Torino, xliv. p. 558 (1894 : Banan); Reichen. Vög. Deutsch-OstAfr. p. 178 (1894).

a. $\&$ ad. Dullaat, July 13, 1894.

b. $\delta$ ad. Boholgarshan, July 15, 1894.

c. $\sigma^{*}$ ad. Hargeisa, July 18, 1894.

Met with by Heuglin on the Upper White Nile.in winter and spring, especially in the country of the Kidj Negroes, from Olibo and Belinian. Antinori procured specimens in August in Shoa. Mr. Jackson found the species as far south as Teita, and it has been pro ' ired in the Oseri River in the Kilima-njaro district.

\section{Fam. Fringillidde.}

\section{Passer swainsoni.}

Passer swainsoni (Rüpp.); Salvad. Ann. Mus. Genov. (2)i. p. 176 (1884); Heugl. Orn. N.O.-Afr. i. p. 634 (1871); Oust. t. c. p. 9 (1886); Sharpe, Cat. B. Brit. Mus. xii. p. 334 (1888); id. Ibis, 1891, p. 257.

a. ‥ Sheik Husein, Sept. 26, 1894. Iris dark brown; angle of mouth yellow; eyes brown.

b. $\sigma^{\circ}$. Sheik Husein, Sept. 26, 1894. Bill black; legs brown; iris rich brown.

Heuglin says that this Sparrow lives in pairs in Kordofan, on the White and Blue Niles, in Uniamuezi, Abyssinia, Bogos-land, and Takah, and is everywhere resident. It is also the resident Sparrow of Shoa, according to Antinori, and occurs as far south as Ukambani, where it was found by Mr. Jackson. In German East Africa its place is taken by $P$. diffusus, according to Dr. Reichenow.

\section{Petronia pyrgita.}

Xanthodina pyrgita, Heugl. Orn. N.O.-Afr. i. p. 627, pl. xxi. fig. 2 .

Gymnorhis pyrgita, Heugl. t. c. App. p. cxl; Shelley, Ibis, 1885, p. 408. 
Petronia pyrgita, Sharpe, Cat. B. Brit. Mus. xii. p. 296 (1888); Reichen. Vög. Deutsch-Ost-Afr. p. 195 (1894).

a. $\delta$ ad. Shebeli, Aug. 25, 1894. Iris light brown.

$b, c$. $\delta$ q ad. Okoto, Sept. 7, 1894. Iris dark brown; bill light horn-colour; legs grey.

d. $q$ ad. Furza, Sept. 12, 1894. Iris brown; bill and feet grey.

Mr. Lort Phillips only observed these Sparrows on one occasion near the centre of the plateau. Heuglin only met with the species in the wooded region on the western slope of the Bogos Mountains towards the lowlands of Barka. According to Dr. Reichenow, it is found as far south as Teita.

\section{Serinus donaldsoni. (Plate XXVII. fig. 2.)}

Serinus donaldsoni, Sharpe, Bull. B. O. Club, iv. p. xli (1895).

S. major. Similis $\mathrm{S}$. capistratæ $\$$, sed subtus concolor, gutture minime maculato : hypochondriis nigro striolatis : fronte viridi, pileo concolore, anguste nigro striolato: supercilio lato flavo: notceo viridi, plumis nigro medialiter striatis; uropygio late flavo distinguendus. Long. tot. $6 \cdot 2$ poll., culm. 0.55, alce $3 \cdot 3$, caudae $2 \cdot 55$, tarsi 0.65 .

a. $\delta$ ad. Smith River, Sept.10, 1894. Bill flesh-colour; iris dark brown. Mr. Gillett also obtained a specimen in the same district.

This large species of Seed-eater is of the size of Serinus sulphuratus, but has the colouring of some of the smaller kinds, such as S. flaviventris. The characters given above, however, will distinguish the species. It comes into the second section of the genus Serinus, as given by me in the 12th volume of the ' Catalogue of Birds,' p. 349, with the flanks streaked with dusky blackish, no yellow frontal patch, but the eyebrow yellow. This would make it an ally of S. capistratus, but it is enormously larger and has no streaks or spots on the throat, the whole under surface being bright yellow. It may also be considered a large edition of S. imberbis, but its streaked flanks and the white margins of the inner secondaries distinguish it.

35. Serinus Maculicoliss. (Plate XXVII. fig. 1.)

Serinus maculicollis, Sharpe, Bull. Brit. Orn. Club, iv. p. xli (1895).

o. S. hypochondriis distincte nigro striolatis: fascia frontali angusta, superciliis, macula auriculari, gutture et pectore totis late flavis: abdomine toto albo, distinguendus. Long. tot. $4 \cdot 4$ poll., culm. 0·35, alce $2 \cdot 7$, caudae $1 \cdot 7$, tarsi $0 \cdot 6$.

o mavi similis, sed gula albida, torque gutturali nigro distinguenda. Long. tot. $4 \cdot 3$ poll., alce $2 \cdot 6$.

This is a curious little Serin Finch, which is apparently unnamed. The yellow colour of the bird is everywhere brighter than in the Canary (Serinus canarius), which appears to be its nearest 
ally, and the white belly is also a conspicuous feature, while the collar of black spots on the fore-neck of the female is quite remarkable. The male has a greyish band across the lower throat.

36. Emberiza poliopleura.

Fringillaria poliopleura, Salvad. Ann. Mus. Civic. Genov. (2) vi. p. 269 (1888).

a. o. Sibbe, Aug. 4, 1894. Mr. Gillett obtained a male on the Shebeli.

b. o. Ehrer, Aug. 16, 1894.

c. Juv. Sheik Husein, Oct. 1, 1894. Iris dark brown; feet light brown.

This species was discovered by Dr. Ragazzi at Soddè in Shoa, where it was pronounced by him to be rare. Count Salvadori (l.c.) has given some excellent notes on the Buntings of this group, and considers Emberiza affinis (Heugl.) to be a distinct species.

\section{Fam. Alaudid e.}

\section{TEPHROCORYS RUFICEPS.}

Calandritis anderssoni (nec Tristr.), Heugl. Orn. N.O.-Afr. i. pt. 2, p. 699 (1871).

Tephrocorys ruficeps (Rüpp.); Sharpe, Cat. B. Brit. Mus. xiii. p. $563(1890)$.

Calandriors ruficeps, Heugl. t. c. p. 698; Salvad. Ann. Mus. Genov. (2) i. p. 170 (1884).

Calandrella ruficeps, Salvad. Ann. Mus. Genov. (2) vi. p. 268.

$a, b$. $\delta$ ad. Sheik Mahomed, Nov. 13, 1894. Iris and legs brown.

Heuglin sars that this species represents our Skylark in the high mountains of Abyssinia, where it is found between 6000 and 11,000 feet. He found it to the north in Hamasien, southwards to the Woho-Gala Mountains, and not to the westward beyond the Tana Lake. In Shoa, Antinori found it in June and November, and Dr. Ragazzi at Fallè, in the Mulo Galla country, in December and January.

38. Spizocorys personata, n. sp.

a. $\delta$ ad. Sassabana, Aug. 3, 1894.

As this specimen is moulting, it is extremely difficult to determine the exact genus it should be placed in; but it has a ver $\bar{y}$ diminutive first primary, and I think that it will prove to be a second species of Spizocorys. From S. curvirostris it is easily distinguished by its vinous breast and abdomen, grey ear-coverts, sides of neck and fore-neck, forming a band across the latter and separating the white throat from the vinous breast. It is also remarkable for the black lores and region of the eyes, the black descending obliquely across the throat and joining a black streak along the anterior malar region. 
39. Alaudula somalica, n. sp.

A. similis A. minori, sed major et rostro conspicue longiore, abdomine albo, subalaribus arenariis et fascia nigra conspicua rictali distinguenda. Long. tot. $5 \cdot 7$ poll., culm. 0.55, alce $3 \cdot 5$, caudce $1 \cdot 95$, tarsi 0.85 .

a. $\delta$. The Haud, July 23, 1894.

Owing to the specimens being in moult, I have had the utmost difficulty in determining the Larks in Dr. Smith's collection, and I am not certain whether the species above described is an Alaudula or a Calandrella. If of the latter genus, it has no near ally, as it has distinct black spots on the throat. In the genus Alaudula it will find its nearest ally in A. minor; but it is a larger bird, with a much longer bill and rufescent under wing-coverts; above all, it is distinguished by the black band which runs from the gape to below the hinder part of the eye.

40. Mirafra gillettit.

Mirafra gilletti, Sharpe, Bull. B. O. Club, iv. p. xxix.

a. Ad. Sibbe, Aug. 4, 1894.

This seems to be quite a distinct species, distinguished by its ashy-brown rump and upper tail-coverts.

\section{Galerita cristata.}

Galerita cristata (Linn.); Heugl. N.O.-Afr. i. p. 680 (1871); Oust. Bibl. Ecole Hautes Études, xxxi. art. 10, p. 8 (1886); Sharpe, Cat. B. Brit. Mus. xiii. p. 626 (1890).

a. Berbera, July 4, 1894.

Belongs to the rufous-tailed race of the Crested Lark (G. senegalensis).

\section{Ammomanes Deserti.}

Ammomanes deserti (Licht.); Heugl. Orn. N. O.-Afr. i. p. 684 (1871); Sharpe, Cat. B. Brit. Mus. xiii. p. 646 (1890).

$a, b . \delta^{\circ}$ ad. Ardeh, July 14, 1894.

This record appears to extend the range of the Desert Lark somewhat further to the southward, as Heuglin only regarded it as a possible inhabitant of the coast district of Somali-land, though he recorded its southern range as $15^{\circ} \mathrm{N}$. lat. in Nubia and on the Abyssinian coast-lands, but not occurring in Abyssinia proper.

\section{Prrrhuladda melanadchen.}

Coraphites melanauchen, Cab.; Heugl. Orn. N.O.-Afr. i. p. 672 (1871).

Pyrrhulauda melanauchen, Sharpe, Cat. B. Brit. Mus. xiii. p. 655 (1890).

a. §. Berbera, July 3, 1894. 
Heuglin gives the range of this little species as along the African coast of the Red Sea and on the Dahlak Islands. Without doubt, he says, it will be found to occur on the coast of Hedjas, and near Berbera in Somali-land. Thus Heuglin's prophecy as to its occurrence at Berbera has been fulfilled by Dr. Donaldson Snith.

\section{Fam. Motacillidie.}

\section{Motacilla vidua.}

Motacilla vidua, Sund.; Heugl. Orn. N.O.-Afr. i. p. 317 (1869); Sharpe, Cat. B. Brit. Mus. x. p. 488 (1885); Reichen. Vög. Deutsch-Ost-Afr. p. 200 (1894).

$a, b$. Imm. Shebeli, Aug. 28, 1894. Iris brown.

Resident in North-eastern Africa, according to Heuglin, but very local. Found in pairs in Southern Egypt and Nubia, southwards to Assouan, only along the Nile. It is also found on the White Nile, on the Atbara, the Azrag, and according to Rüppell in Abyssinia. Dr. Reichenow gives many localities, ranging from the Pangani River and Ugogo to the Victoria Nyanza.

\section{Motacilla flava.}

Motacilla flava, Linn. ; Heugl. Orn. N.O.-Afr. i. p. 320 (1869); Sharpe, Cat. B. Brit. Mus. x. p. 516, pl. vi. figs. 3-5 (1885).

Budytes flc us, Salvad. Ann. Mus. Genov. (2) i. p. 166 (1884); Reichen. Vög. Deutsch-Ost-Afr. p. 200 (1894).

a. $q$ ad. Sheik Husein, Sept. 19, 1894. Iris and feet dark brown; bill black, the base of the under mandible yellowochre.

Heuglin found Yellow Wagtails in Egypt, Arabia, Nubia, on the White Nile and Gazelle Rivers, in Abyssinia and Bogos-land, and on the Somali coast.

In Shoa, Antinori met with it in November, and again on the 1st of May at Mahal-Uonz. Dr. Reichenow gives a long list of localities in East Africa from which he has seen specimens.

\section{Anthus trivialis.}

Anthus arboreus (Gm.) ; Heugl. Orn. N.O.-Afr. i. p. 324 (1869). Anthus trivialis (Linn.); Sharpe, Cat. B. Brit. Mus. x. p. 543 (1885) ; id. Ibis, 1891, p. 588 ; Reichen. Vög. Deutsch-Ost-Afr. p. 199 (1894).

a. $\delta^{+}$ad. Sheik Husein, Sept. 29, 1894. Iris dark brown; legs and under mandible very light grey.

A somewhat scarce winter visitant in Egypt, according to Heuglin. Hemprich and Ehrenberg met with it in Nubia and Arabia, and Lefebvre in September at Schiriè in East Abyssinia. Mr. Jackson procured it on Mt. Elgon at 8000 feet in February, and Dr. Reichenow records it from Kakoma. 


\section{Tmetothylacus tenellus.}

Anthus tenellus (Cab.); Sharpe Cat. B. Brit. Mus. x. p. 618. Macronyx tenellus, Oust. Bibl. École Hautes Études, xxxi. art.10, p. 8 (1886); Reichen. Vög. Deutsch-Ost-Afr. p. 200 (1894).

Tmetothylacus tenellus, Salyad. Mem. R. Accad. Sci. Torino, (2) xliv. p. 557 (1894: Lido Mountains).

a. $q$ imm. Darar, Sept. 15, 1894. Iris dark brown; bill dark grey, the under mandible lighter; feet light brown.

Has been found in the Parè Mountains by Dr. Fischer.

\section{Fam. Nectarinimd}

48. Cinnyris osiris.

Nectarinia osiris, Finsch, Tr. Zool. Soc. vii. p. 230 (1870).

Cinnyris osiris (Finsch); Shelley, Monogr. Nect. p. 215, pl. 64. fig. 1; Salvad. Ann. Mus. Genov. (2) i. p. 140 (1884), vi. p. 245 (1888); Sharpe, Ibis, 1891, p. 593.

a. $\delta$ ad. Milmil, July 26, 1894.

b, c. of ad. Sheik Husein, Sept. 25, 1894.

Found by Antinori on the elevated "Kolla" lands of Shon, where it seems to be common. Mr. Jackson procured it as far south as Machako's, and Mr. Lort Phillips has lately met with the species on the Goolis Mountains.

49. Cinnyris albiventris.

Nectarinia albiventris, Strickl.; Heugl. Orn. N.O.-Afr. i. p. 234 (1869).

Cinnyris albiventris, Shelley, Monogr. Nect. pl. 73 (1876); Salvad. Mem. R. Accad. Torino, (2) xliv. p. 556 (1894: Maudera, Goolis Mts.).

a. $\delta$ ad. The Haud, July 22, 1894.

b, c. $\delta$ ad. Gardubbla, Aug. 15, 1894.

d. of ad. Shebeli, Sept. 6, 1894. Iris dark brown: breeding.

This species was only known to Heuglin from the Somali plateau.

\section{Cinnyris habessinica.}

Nectarinia habessinica, H. \& E. ; Heugl. Orn. N.O.-Afr. i. p. 229 (1871).

Cinnyris habessinica, Shelley, Monogr. Nect. pl. 63 (1878); Salvad. Ann. Mus. Genov. (2) i. p. 139 (1884); Shelley, Ibis, 1885 , p. 406 ; Salvad. t. c. p. 556 (1894: Goolis Mts.).

a. $\delta$ ad. Boholgarshan, July 15, 1894.

$b, c$. $\delta$ ad.; $d$. + ad. Selon, Ang. 7, 1894. Iris black. Breeding.

e. $\delta$ ad. Turfa, Aug. 21, 1894.

$f$. + ad. Okoto, Sept. 8, 1894. Iris dark brown.

g. of ad. Dada, Nov. 21, 1894 . Iris brown. 
According to Heuglin, this Sun-bird is found in the country bordering the Red Sea, extending to the mountains near Suakin, and to those south of the Somali coast. It is found from the seacoast up to 3000 and 4000 feet, but was not seen in the interior of Abyssinia ; it is not rare in Takah. Heuglin thinks that Harris's specimens, said to have been procured in Shoa, must really have been obtained on the Adail coast; but Antinori states that it is common during the whole year in the low as well as the high "Kolla."

\section{Chalcomitra hunteri.}

Chalcomitra hunteri, Shelley, P. Z. S. 1889 , p. 365, pl. xli. fig. 2 (Oseri River); Salvad. t. c. p. 556 (1894: Goolis Mts.).

Cinnyris hunteri, Sharpe, Ibis, 1891, p. 592 ; Reichen. Vög. Deutsch-Ost-Afr. p. 210 (1894).

a. Ad. Sillul, Aug. 5, 1894.

This Sun-bird was discovered by Mr. Hunter on the Oseri River in the Kilima-njaro district. Mr. Jackson met with it on the Voi River in Teita in December.

Count Salvadori has recently recorded the species from the Goolis Mountains, where, however, Mr. Lort Phillips has not yet found it.

\section{Anthothreptes orientalis.}

Anthreptes orie alis, Hartl. J. f. O. 1880, p. 213.

Anthreptes longuemarii (Less.); Shelley, P. Z. S. 1888, p. 39.

Anthothreptes longuemarii, Sharpe, Ibis, 1891, p. 594 .

Antrotreptes longuemarii, Reichen. Vög. Deutsch-Ost-Afr. p. 209 (1894).

a. + ad. Okoto, Sept. 8, 1894. Iris dark brown.

$b$. o ad. Smith's River, Sept. 10, 1894.

c. Ad. Dabulli, Sept. 16, 1894.

These specimens agree with others from Equatorial Africa collected by Emin Pasha. A. orientalis seems to me always to be distinguishable by the bright metallic-green band across the lower back, this band being absent in $A$. longuemarii.

The species obtained by Heuglin on the Wa River in April was doubtless $A$. orientalis, and he also met with it in winter plumage in January. Antinori procured the same bird in the Djur and Dor districts. It is certainly the species procured by Mr. Jackson from the Teita district, and I have little doubt that it is also the form recorded from so many places in Eastern Africa by Dr. Reichenow.

\section{Fam. Zosteropide.}

\section{Zosterups Flavilateralis.}

Zosterops flavilateralis, Reichen. J. f. O. 1892, p. 192 ; id. Vög. Deutsch-Ost-Afr. p. 208 (1894). 
Zosterops tenella, Hartl.; Oust. Bibl. École Hautes Études, xxxi • art. 10, p. 8 (1886).

a. of ad. Sillul, Ang. 7, 1894. Iris light brown. Feet dark grey.

I believe that I have correctly identified this species, which is recorded by Dr. Reichenow from Masai-land on the Maeru Mountains, Aruscha, and Kilima-njaro.

Fam. Paride.

54. Parus thruppi.

Parus thruppi, Shelley, Ibis, 1885, p. 406, pl, xi. fig. 2.

a. of ad. Milmil, July 27, 1894.

Discovered by Mr. Lort Phillips near the centre of the Somali plateau.

55. Agithalus muscults.

Egithalus musculus, Hartl.; Shelley, P. Z. S. 1888, p. 29.

$a, b . \sigma^{*}$ ad. Okoto, Sept. 8, 1894. Iris dark brown; legs bluish grey.

This is an Equatorial species, which has not hitherto been recorded from Somali-land or East Africa.

\section{Fam. Laninde.}

\section{Lanius isabellinus.}

Lanius isabellinus, H. \& E. ; Heugl. Orn. N.O.-Afr. ii. p. 475 (1871); Gadow, Cat. B. Brit. Mus. viii. p. 277 (1883); Reichen. Vög. Deutsch-Ost-Afr. p. 158 (1894).

a. $\delta$ ad. Bunker Dagabourh, Dec. 22, 1894. Iris brown.

Not plentiful in North-eastern Africa, south of $15^{\circ} \mathrm{N}$. lat. in Kordofan; on the White Nile, in Senar, and in Abyssinia ; obtained by Ehrenberg near Quofuda, on the Arabian coast (Heuglin). It is a winter visitor to East Africa, according to Dr. Reichenow, and has been obtained at Bagamoyo, on the Pangani River, the Wembaere Steppes, Tavéta, and Bukoba.

\section{Lanius humeralis.}

Lanius humeralis, Stanl. ; Heugl. Orn. N.O.-Afr. i. p. 486 (1871); Salvad. Ann. Mus. Genov. (2) i. p. 130 (1884), vi. p. 240 (1888); Sharpe, Ibis, 1891, p. 597; Reichen. Vög. Deutsch-Ost-Afr. p. 157 (1894).

a. $\delta$ ad. Tuago, Oct. 27, 1894. Iris dark brown.

Heuglin says that this is a very common bird in Abyssinia, apparently a resident, but not found above $8000-10,000$ feet. $\mathrm{He}$ collected it northwards to the Province of Takab, and to the southward to Fazogl, more rarely in Southern Kordofan, and on the White Nile.

In Shoa the present species was met with by Antinori at Mahal- 
Uonz from March to August, breeding in June. Dr. Ragazzi also records it from various localities in Shoa between November and June. Mr. Jackson procured it in Elgeyo (July), in Kikuyu (August), and on Mount Elgon (February); and, according to Dr. Reichenow, it extends south to Igónda, Kilima-njaro, Aruscha, and Bukoba.

58. LaniUs antinoriI.

Lanius antinorii, Salvad.; Gadow, Cat. B. Brit. Mus. viii. p. 255 (1883).

a. of ad. Labarouk, July $12,1894$.

b. + ad. The Haud, July 24, 1894.

These specimens are undoubtedly $L$. antinorii, but Mr. Gillett obtained a specimen near Gelaydee which is the true $L$. dorsalis, Cab., as also is Mr. Lort Phillips's example recorded by Capt. Shellev from Somali-land ('Ibis,' 1885, p. 401). Mr. Jackson's specimen from Turquel ('Ibis,' 1891 , p. 295) is also true $L$. dorsalis, with black inner secondaries. I should not be surprised, notwithstanding that Dr. Smith's specimens are determined as male and female, to learn that $L$. antinorii and $L$. dorsalis are sexes of the same species. $C f$. Salvadori, Mem. R. Accad. Torino, (2) xliv. p. 555 (1894).

\section{Laniarius cruentus.}

Dryoscopus cruentus (Rüpp.) ; Heugl. Orn. N.O.-Afr. i. p. 462 (1871).

Laniarius cruentus (H. \& E.); Gadow, Cat. B. Brit. Mus. viii. p. 152 (1883); Shelley, Ibis, 1885, p. 402.

Rhodophoneus cruentus, Salvad. Mem. R. Accad. Torino, (2) xliv. p. 555 (1894).

a. + ad. The Haud, July 25, 1894.

b. + ad. Dacheto, Aug. 10, 1894. Iris light brown; legs grey.

c. $\delta$ ad. Sheik Husein, Sept. 23, 1894. Iris dark brown; legs light grey.

According to Heuglin, the range of this species is decidedly restricted to certain districts. He found it only along the African coast of the Red Sea from Suakin south to Adël-land, and he considers it to be a bird of the lowlands rather than of the mountains, which it seldom visits.

60. Laniarius poliocephalus.

Meristes olivaceus (nec V.); Heugl. Orn. N.O.-Afr. i. p. 466 (1871).

Laniarius potiocephalus (Licht.); Gadow, Cat. B. Brit. Mus. viii. p. $156(1883)$

a. Ad. Bainhou, Jan. 10, 1895. Iris golden yellow; legs grey.

Antinori considered this species to extend no further than $8^{\circ}$ or 
$9^{\circ} \mathrm{N}$. lat., and to be migratory between the 20th of February and the 10th of March on the Upper Nile. Heuglin, on the other hand, believed the species to be resident, as he met with it in November and December, and again in March, on the plains of Hamedo in the Abyssinian lowlands, in April in the "Quola" of Western Abyssinia, in Kordofan in July, and in Bongo between August and November.

In Shoa Antinori met with the allied species L. hypopyrrhus.

\section{Dryoscopus athiopicus.}

Dryoscopus athiopicus (Gm.); Heugl. Orn. N.O.-Afr. i. p. 458 (1871) ; Gadow, Cat. B. Brit. Mus. viii. p. 139 (1883); Reichen. Vög. Deutsch-Ost-Afr. p. 163 (1894).

Laniarius athiopicus, Salvad. Ann. Mus. Genov. (2) i. p. 132 (1884), vi. p. 240 (1888).

a. $q$ ad. Mount Kuldush, Dec. 18,1894. Iris reddish brown; legs grey.

Found in pairs, according to Heuglin, in Abyssinia and Takah, northwards to $17^{\circ} \mathrm{N}$. lat. on the Upper White Nile, less commonly in Senar and Kordofan. It extends up the mountains higher than D. gambensis, but not beyond 8000 feet.

Antinori found the species in Shoa, but rather sparsely, near Let-Marafià. Dr. Ragazzi, however, mentions it as common in Shoa. Dr. Reichenow records it from Aruscha, Kilima-njaro, and Karéma.

\section{Dryoscopus gambensis.}

Dryoscopus gambensis, Licht.; Heugl. Orn. N.O.-Afr. i. p. 456 (1871); Gadow, Cat. B. Brit. Mus. viii. p. 146 (1883); Salvad. Ann. Mus. Genov. (2) vi. p. 241 (1888).

a. $q$ ad. Walenso, Oct. 26, 1894 . Iris red; bill, under mandible grey, upper mandible black ; legs grey.

A resident in North-eastern Africa, according to Heuglin, by whom it was obtained to the eastward as far as the Anseba River, in Senar, Kordofan, and the region of the Nile. On the mountains of Abyssinia it ascends to 6000 feet. He describes a female bird from the Schir Negroes country on the Upper White Nile. Dr. Ragazzi procured the species in Shoa in the forests of FekerièGhem, Sciotalit, and the Gherbà Falls.

\section{DRYoscopUs FUNEBRIS.}

Dryoscopus funebris, Hartl.; Heugl. Orn. N.O.-Afr. i. p. 461 (1871); Gadow, Cat. B. Brit. Mus. viii. p. 133 (1883); Sharpe, Ibis, 1891, p. 598; Reichen. Vög. Deutsch-Ost-Afr. p. 162 (1894).

Laniarius funebris, Salvad. Ann. Mus. Genov. (2) i. p. 133 (1884), vi. p. 241 (1888).

$a, b . \delta$ a ad. Sillul, Aug. 7, 1894. Iris dark brown. 
First obtained by Speke at Meninga in Equatorial Africa. Two specimens, which Count Salvadori believes to be of this species, were obtained by Antinori at Ambo-Karra, in Shoa, in July and August. Dr. Ragazzi obtained a female at Muca in May, but it was not common. It extends south as far as the Teita district, where it was procured by Mr. Jackson at Nzoni, and is widely spread over East Africa down to Ugogo.

64. Dryoscopus rufinuchalis, n. sp.

Similis $\mathrm{D}$. ruficipiti, sed fronte et vertice nigris, occipite nuchaque rufis distinguendus. Long. tot. $7 \cdot 1$ poll., culm. $0 \cdot 75$, ald 3 , caudae $3 \cdot 15$, tarsi $1 \cdot 05$.

a. $\delta$ ad. Dabulli, Sept. 16, 1894. Legs grey; iris dark brown.

b. $\delta$ ad. Tooloo Duroo, Nov. 25, 1894.

c. Ad. ? ?, Dec. 1, 1894.

All Dr. Donaldson Smith's specimens differ from the type in the Lort Phillips collection in having the fore part of the crown black, as well as the forehead. In the typical specimen the forehead only is black, so that there is not half the amount of black on the crown of the head. This may only be sexual. A specimen got by Mr. Gillett is also stated to be a male, like two of those procured by Dr. Smith. On the other hand, it is so remarkable that four specimens obtained on the present expedition should all agree together and all differ from the type in such a marked way, that I have come to the co slusion that the differences are specific.

\section{Telephonus Jamesi.}

Telephonus jamesi, Shelley, Ibis, 1885, p. 403, pl. x. fig. 2; Oust. t. c. p. 5 (1886).

a. Bussarler, Nov. 28, 1894. Legs grey; iris brown, with light spots.

\section{Telephonus blanfordi.}

Telephonus erythropterus, pt., Heugl. Orn. N.O.-Afr. i. p. 468 (1871).

Telephonus blanfordi, Sharpe; Gadow, Cat. B. Brit. Mus. viii. p. 127 , pl. 2. fig. 2 (1883); Salvad. Ann. Mus. Genov. (2) i. p. 119 (1884), vi. p. 242 (1888 sesharpe, Ibis, 1891, p. 600.

a. $\delta$ ad. Sheik Husein, Sept. 2ै, 1894. Iris purple, with small white spots; legs bluish grey.

This Bush-Shrike breeds in Shoa, where Antinori met with it at Daimbi in the Adda Galla country and at Let-Marafià, Algaber, Mahal-Uonz, and Denz. Mr. Jackson obtained a specimen at Kitosh in March.

67. Nilaus minor, subsp. n.

Nilaus brubru (Lath.); Salvad. t. c. p. 555 (1894).

N. similis N. capensi, sed conspicue minor. Long. tot. $5 \cdot 1$ poll., culm. $0 \cdot 65$, alce 3 , caudce $1 \cdot 9$, tarsi $0 \cdot 75$. 
a. $\delta$ ad. Milmil, July 2, 1894 .

b. of ad. Sibbe, Julv 3, 1894.

c. $q$ ad. The Haud, July 24, 1894 .

d. of ad. Okoto, Sept. 8, 1894. Iris dark brown; legs dark grey.

It is very interesting to find a race of the South-African $N$. capensis in Somali-land, as the N.E.-African $N$. afer or Reichenow's $N$. nigritemporalis might have been expected. I can find no difference between the Somali and Cape examples beyond the conspicuously smaller size of the former and a certain degree of more white at the tips of the inner primaries. The same small race occurs in the Teita district, where a specimen was procured by Sir Robert Harvey.

68. Prionops cristatus.

Prionops poliocephalus (nec Stanl.); Shelley, Ibis, 1885, p. 403; id. P. Z. S.

Prionops cristatus, Sharpe, Ibis, 1892, p. 601.

a. $\delta$ ad. The Haud, July 24, 1894. Iris and eyelid strawyellow ; legs coral-red.

\section{Eurocephalus rueppelli.}

Eurocephalus rueppelli, Bp.; Heugl. Orn. N.O.-Afr. i. p. 487; Sharpe, Cat. B. Brit. Mus. iii. p. 280 (1877); Shelley, Ibis, 1885, p. 403 ; Oust. t. c. p. 5 (1886) ; Salvad. Ann. Mus. Genov. (2) vi. p. 243 (1888); Reichen. Vög. Deutsch-Ost-Afr. p. 160 (1894).

a. of ad. Milmil, July 28, 1894.

b. Juv. Milmil, July 28, 1894.

c. + ad. Sheik Husein, Sept. 29,1894 . Iris dark brown; eyelids fleshy, black in colour.

The young bird from Milmil has the crown of the head brown, the hinder crown and nape creamy white, the back has obscure pale edges to the feathers, and the wing-coverts are distinctly margined with sandy buff, as also are the inner secondaries. The ear-coverts also are white, with the fore part of the face black, and some black mottlings on the side of the neck.

Rüppell met with this specif in Shoa, and Heuglin obtained several examples from the Uppes White Nile, south of $9^{\circ} \mathrm{N}$. lat., in February and March. Dr. Ragazzi also found it at Assakalel in Shoa, and Antinori noticed the species near Jerarudda in the Somali-Isa district. According to Dr. Reichenow, this species is widely distributed in East Africa, and he gives the names of many localities between Ugogo and Speke Gulf on the Victoria Nyanza.

70. Bradyornis pumilus, n. sp.

B. similis B. murino, sed conspicue minor, et secundariis late fulvo marginatis. Long. tot. $5 \cdot 9$ poll., culm. $0 \cdot 6$, ala $3 \cdot 2$, caudae $2 \cdot 45$, tarsi $0 \cdot 85$.

a. $\delta$ ad. Hargeisa, July 17, 1894. 
b. Ad. Hargeisa, July 18, 1894.

c. Ad. The Haud, July 23, 1894.

d. ㅇ ad.; e. of imm. Schebeli, Sept. 9, 1894. Iris dark brown.

This bird is a small race of $B$. murinus. It is so much greyer than $B$. pallidus that it cannot be confounded with it, when once the two species are compared. There are some evidences of dusky streaks on the head, which give to the bird, at first sight, a resemblance to Muscicapa grisola.

71. Melanornis schistacea, n. sp.

M. similis M. atræ, sed ubique schistacea, et remigibus intus albo murginatis distinguenda. Long. tot. 8 poll., culm. 0.55, alas 4, cauda 4 , tarsi 0.9 .

a. Ad. Darro Mountains, Nov. 19, 1894.

The grey colour of this species easily distinguishes it from $M$. atra, but, in addition to that, the white quill-lining is very conspicuous.

Fam. Sylvinde.

72. Phylloscopus tror tilus.

Phyllopseuste trochilus (L.); Heugl. Orn. N.O.-Afr. i. p. 298 (1869).

Phylloscopus trochilus, Seeb. Cat. B. Brit. Mus. v. p. 56 (1881); Sharpe, Ibis, 1892, p. 153 ; Reichen. Vög. Deutsch-Ost-Afr.p. 232 (1894).

a. Ad. Sheik Mahomet, Nov. 9, 1894.

Heuglin states that our Willow-Wren is a plentiful visitor to North-eastern Africa in winter, and he procured specimens at Khartoum and Berber at the end of August and the beginning of September. It goes south to Abyssinia, Kordofan, and the White Nile districts. Mr. Jackson shot one in Ukambani in March, and Dr. Reichenow records it from the Ronga River and Parè in winter.

\section{Eremomela flavicrissalis. n. sp.}

Similis E. flaviventri, sed supra sordide schistacea, minime olivascens: subtus alba, hypochondriis imis, crisso et subcaudalibus pallide sulphureis distinguenda. Long. tot. 3.5 poll., culm. 0.35, alce $1 \cdot 95$, caudae 0.95 , tarsi 0.65 ,

a. Ad. Shebeli, Sept. 6, 1894. Iris yellow-ochre.

This little species is very similar to E. flaviventris and E. griseoflava, but is easily distinguished by the small amount of yellow on the underparts, which does not reach above the line of the thighs. The upper surface is of a darker slate-colour, very perceptibly so on comparison of specimens, and the tail-feathers have narrow white fringes, not ashy olive as in E. flaviventris.

Proc. Zool. Soc.-1895, No. XXXI. 


\section{Calamonastes simplex.}

Erythropygia simplex (Cab.) ; Sharpe, Cat. B. Brit. Mus. vii. p. 74 (1883).

Thamnobia simplex, Salvad. Ann. Mus. Genov. (2) vi. p. 251 (1888).

Calomonastes simplex, Sharpe, Ibis, 1892, p. 154 ; Reichen. Vög. Deutsch-Ost-Afr. p. 225 (1894).

a. $\delta$ ad. Milmil, July 30, 1894.

$b$. $\sigma^{*}$ ad. Okoto, Sept. 8, 1894. Iris reddish brown; legs purple-brown.

c. Ad. Sheik Husein, Oct. 2, 1894. Iris and legs light brown.

Mr. Lort Phillips has recently procured this species on the Goolis Mountains. Dr. Ragazzi obtained it at Soddè, in Shoa, in August. Mr. Jackson met with it at Turquel in January and at the River Voi, in Teita, in December. Dr. Reichenow also gives the Parè Mountains, Nguruman, and the Pangani River as localities for the species.

\section{Sylviella micrura.}

Oligocercus rufescens (nec V.); Heugl. Orn. N.O.-Afr. i. p. 236 (1869).

Sylviella micrura (Rüpp.) ; Sharpe, Cat. B. Brit. Mus. vii.p. 154 (1883).

Sylvietta micrura, Salvad. Ann. Mus. Genov. (2)i. p. 145 (1888), vi. p. 251 (1888).

a. 우 ad. Fehja, Nov. 23, 1894. Iris red; legs light brown.

According to Heuglin, this species is found singly or in pairs in North-eastern Africa, below $16^{\circ}$ or $17^{\circ} \mathrm{N}$. lat. On the African coast of the Red Sea it extends from Takah to Adel-land, and is found in Bogos-land and the warmer parts of Abyssinia, as well as in Southern Nubia, Kordofan, Senar, and on the Nile and its tributaries. Antinori procured it at Ambo-Karra in August and on the "Kolla" of Aigaber in Shou in October, and Dr. Ragazzi at Cialalakà in June.

\section{Dryodromas smithi.}

Dryodromas smithi, Sharpe, Bull. B. O. C. iv. p. xxix.

a. $\delta$ ad. Shebeli, Sept. 4, 1894. Iris yellow-ochre; legs flesh-colour.

$b$, c. o imm. Sheik Husein, Sept. 27, 1894. Iris light brown; eyelids yellow-ochre; legs light brown.

Differs in the greater amount of white on the outer tail-feathers, which have the outer web entirely white. The type-specimen has also distinct white edges to the wing-coverts and inner secondaries, but these are are not so plain in the two specimens from Sheik Husein, which are like D. rufifrons, but show much more white on the outer tail-feathers. 
77. Cisticola dodsoni.

Cisticola dodsoni, Sharpe, Bull. B. O. Club, iv. p. xxix.

a. + ad. The Haud, July 25, 1894.

78. Cisticola marginalis.

Cisticola marginata, Heugl. Orn. N.O.-Afr. i. p. 248 (1869); Reichen. Vög. Deutsch-Ost-Afr. p. 223 (1894).

Cisticola marginalis (Heugl.); Sharpe, Cat. B. Brit. Mus. vii. p. 258 (1883).

a. $\delta^{\circ}$ ad. Sheik Mahomed, Nov. 4, 1894. Iris and legs light brown.

Heuglin obtained this species only on the Upper White Nile, the Gazelle River, and on the Lower Bahr-el-Djebel. Said by Dr. Reichenow to have been obtained at Tabóra in East Africa.

79. Cisticola somalica, sp. n.

Similis C. hæsitatæ, sed major et uropygio cinerascente concolore distinguenda. Long. tot. $4 \cdot 6$ poll., culm. 0*6, alce 2·15, cauda $1 \cdot 9$, tarsi $0 \cdot 8$.

a. + ad. Milmil, July 26, 1894 .

b. of ad. Ehrer, Aug. 1, 1894.

Although very similar to $C$. hasitata of Socotra, this species is so much larger that it is impossible to believe that they can be identical. The rump also is uniform ashy, whereas it is distinctly mottled with darker centres in C. hasitata. Another African species with which it seems to be related is $C$. lugubris, which it resembles in size, but is easily recognizable by its strongly streaked head and neck, the dark streaks being equally distinct on the sides of the face. It is also of a paler grey, and is further distinguished by the absence of rufous on the wing.

This species is evidently closely allied to C. cinereola of Salvadori (Ann. Mus. Genov. 2, vi. p. 254) from Farrè in Shoa, but is apparently distinguished by the strong shade of buff on the underparts and by the colour of the feet, which are dark yellowish brown, and could not be called pale horn-colour.

\section{Fam. Turdide.}

80. Erythropygia ledcoptera.

Aëdon leucoptera (Rüpp.); Heugl. Orn. N.O.-Afr. i. p. 279 (1869); Salvad. Ann. Mus. Genov. (2) i. p. 152 (1884).

Erythropygia leucoptera, Sharpe, Cat. B. Brit. Mus. vii. p. 79 (1883); Shelley, Ihis, 1885 , p. 406 ; Salvad. Ann. Mus. Genov. (2) vi. p. 255 (1888).

a. $\delta$ ad. Dullaat, July 13, 1894.

b. $q$ ad. Hargeisa, July 21, 1894.

c. Ad. Shebeli, Sept. 6, 1894. Iris dark brown; base of under mandible yellow-ochre. 
d. $\delta$ ad. Okoto, Sept. 7, 1894. Iris dark brown; base of under mandible yellow-ochre; legs light horn-colour.

e. $\delta$ ad. Sheik Husein, Sept. 24, 1894. Iris dark brown ; base of under mandible yellow-ochre ; legs light grev.

This is a Shoan species, and was not known to Heuglin from any other locality. It is rare in that country, according to Antinori, but Dr. Ragazzi appears to have met with it more plentifully near Ambokarra in May, and at the Farrè Falls in March and July.

\section{Cossypha donaldosoni.}

Cossypha donaldsoni, Sharpe, Bull. B. O. Club, iv. p. xxviii (March, 1895).

a. ․ Sheik Husein, Sept. 28, 1893 . Iris dark brown.

This new species is closely allied to Cossypha subrufescens of Bocage, but the back is dark grey, as also are the wings, the quills not showing the light grey margins which are seen in C.subrufescens. This species is further distinguished by its uniform outer tailfeathers, which do not show the dusky edgings seen in the lastnamed species and in $C$. heuglini also.

\section{Cichladusa guttata.}

Cichladusa guttata, Heugl. Orn. N.O.-Afr. i. p. 374 (1869); Sharpe, Cat. B. Brit. Mus. vii. p. 70 (1883); Oust. Bibl. École Hautes Études, xxxi. p. 6 (1886); Sharpe, Ibis, 1892, p. 160; Reichen. Vög. Deutsch-Ost-Afr. p. 227 (1894).

a. $\delta$ ad. Moodenner, Nov. 26, 1894. Iris reddish brown.

This species was found by Heuglin only at Aniob, in the Kidj Negro district, and on the banks of the Bahr-el-Djebel. Mr. Jackson met with it at Njemps, on Lake Barengo, in July, and it occurs at different places from Lake Naivascha to the coast-region of Baramoyo, and the Pangani River.

\section{Geocichla simensis.}

Turdus simensis (Rüpp.); Heugl. Orn. N.O.-Afr. i. p. 380 (1869).

Geocichla simensis, Seeb. Cat. B. Brit. Mus. v. p. 183 (1881).

Psophocichla simensis, Salvad. Anu. Mus. Genov. (2) i. p. 158 (1884), vi. p. 258 (1888).

a. + ad. Sheik Mahomed, Nov. 1, 1894. Iris dark brown.

Heuglin states that this is one of the commonest species in the Abyssinian highlands, from the Pass of Taranta and Mensa to Western Amhara, south to the Gala country, but never found below 5000 feet.

Common in Shoa, at Licce and Fecheriè-Ghem, from October to February, according to Antinori. It was also found to be very common at Fallé in January by Dr. Pagazzi. 


\section{Turdus AByssinicus.}

Turdus olivacinus, Bp.; Heugl. Orn. N.O.-Afr. i. p. 382 (1869).

Turdus abyssinicus, Gm.; Seeb. Cat. B. Brit. Mus. v. p. 228 (1881); Salvad. Ann. Mus. Genov. (2) i. p. 159 (1884), vi. p. 258 (1888).

a. + juv. Sheik Mahomed, Nov. 4, 1894. Iris dark brown; legs orange ; bill yellowish brown.

b. $q$ ad. Sheik Mahomed, Nov. 7, 1894. Iris dark brown; eyelids yellow-ochre; bill orange; legs bright yellow.

Distributed over the whole of Abyssinia, according to Heuglin, but only met with at an elevation of from 7000 to 11,000 feet above the sea. In Wolo-land he met with it up to 12,000 feet.

Antinori states that the species is not rare in Shoa, in Arramba and Ankober, nesting in February in the forests of this portion of the "Kolla." Dr. Ragazzi also found it to be very common in Shoa.

\section{Monticola saxatilis.}

Monticola saxatilis (L.); Heugl. Orn. N.O.-Afr. i. p. 370 (1869); Seeb. Cat. B. Brit. Mus. v. p. 313 (1881); Salvad. Ann. Mus. Genov. (2) i. p. 160 (1884); Sharpe, Ibis, 1892, p. 161; Salvad. Mem. R. Accad. Torino, (2) xliv. p. 556 (1894).

a. $\&$ ad. Webe Shebeli, Dec. 16, 1894. Iris dark brown.

Heuglin records the Rock-Thrush as a spring and autumn migrant in N.E. Africa, not rare in Egypt, Nubia, and Arabia. Some remain during the winter, others going south. $\mathrm{He}$ met with this species on the Gazelle River $\left(7^{\circ}-8^{\circ} \mathrm{N}\right.$. lat.) in November, near Aden in December and January, and also on the higher mountains of Abyssinia. It was procured by Antinori in Shoa, at Mahal-Uonz in March, and at Algaber in October. Mr. Jackson found it as far south as Ukambani, and, according to Dr. Reichenow, it has been procured at Bagamoyo, Igónda, and Kagéyi in German East Africa.

\section{Saxicola isabelina.}

Saxicola isabellina, Rüpp.; Heugl. Orn. N.O.-Afr. i. p. 344 (1869); Seeb. Cat. B. Brit. Mus. v. p. 399 (1881); Shelley, Ibis, 1885, p. 405; Salvad. Ann. Mus. Genov. (2) i. p. 164 (1884), vi. p. 36 (1888); Sharpe, Ibis, 1892, p. 162 ; Reichen. Vög. DeutschOst-Afr. p. 236 (1894).

a. of ad. Ummayer, Dec. 3, 1894. Iris brown.

This is a very large specimen (wing $4 \cdot 15$ ), with a reddishbrown crown, and the rufous-brown on the rump strongly marked. I notice, however, a tendency in many individuals in our large series in the Museum to vary in these particulars, and I have therefore come to the conclusion that Dr. Smith's specimen is only a particularly fine one.

The Isabelline Wheatear, according to Heuglin, is a resident 
bird in Abyssinia, and breeds in Semien up to 10,000 feet. It is found singly, in autumn, winter, and spring, in Egypt, Arabia, and on the islauds and coast of the Red Sea, as well as in Somaliland, Nubia, and Kordofan. Antinori procured a specimen at Daimbi, in Shoa, in November. Mr. Jackson found this Wheatear very plentiful in January in Turquel, at the foot of Mount Elgon, and it has been procured by Dr. Fischer on Lake Naiwascha, and near Kipini in Formosa Bay.

87. Saxicola genanthe.

Saxicola oenanthe (L.); Heugl. Orn. N.O.-Afr. i. p. 347 (1869); Seeb. Cat. B. Brit. Mus. v. p. 391 (1881); Oust. t. c. p. 7 (1886); Sharpe, Ibis, 1892, p. 162.

a. $q$ ad. Sheik Husein, Sept. 23, 1894. Iris dark brown.

Our European Wheatear is said by Heuglin to be a winter visitant to North-eastern Africa and Arabia, south as far as the lake districts of the Upper Nile. Mr. Jackson procured a specimen at Kitina, in January, and Dr. Reichenow records the species as a winter visitant to Igónda, Ugálla, Ussáre, and Kagéyi in German East Africa.

\section{SAXICOLA PHILLIPSI.}

Saxicola phillipsi, Shelley, Ibis, 1885 , p. 404, pl. xii.; Salvad. t. c. p. 556 (1894).

a. o ad. Hargeisa, July 16, 1894.

89. Saxicola SOMALICA, n. sp.

S. similis S. morioni, cauda eodem modo notata, sed gula alba distinguenda. Long. tot. $6 \cdot 4$ poll., culm. $0 \cdot 5$, alce $3 \cdot 7$, caudae $2 \cdot 45$, tarsi $1 \cdot 85$.

a. of imm. [?]. Doda, Nov. 21, 1894. Iris brown.

After a careful comparison of examples of all the species of Saxicola in the British Museum, I have been unable to refer this specimen to any one of them. The bird is in winter plumage, and is in most respects like the winter plumage of $S$. morio. The black on the ear-coverts and on the sides of the neck is developing plainly, but the throat, which in the parallel plumage of S. morio is also black, is white in S. somalica; nor can I trace any sign of underlying black plumage, which is aiways observable in S. morio. I am therefore under the impression that the species is quite distinct from the last-mentioned bird.

90. Myrmecocichla melanura.

Saxicola melanura (Temm.); Heugl. Orn. N.O.-Afr. i. p. 361 (1869).

Myrmecocichla melanura (Temm.); Seebohm, Cat. B. Brit. Mus. v. p. 361 (1881); Oust. Bibl. École Hautes Études, xxxi. art. 10, p. 7 (1886).

$a, b$. Ad. Daragoody, July 11, 1894. 
These specimens agree with the series in the British Museum from Aden and Abyssinia; but these all differ from the form found in Palestine, which seems to me to be quite distinct, and which I have named $M$. yerburyi (Bull. B. O. C. iv. p. xxxvi).

Heuglin says that this species is found, mostly in pairs, from Arabia Petræa south to Aden, and in the mountain valleys between Berber and Suakin, in Central and Southern Nubia, and in the rocky districts near Massowa, on most of the islands of the Danakil coast, near Tedjura, and in the country of the Eisa Somalis.

\section{Pratincola albifasciata.}

Pratincola semitorquata, Heugl. Orn. N.O.-Afr. i. p. 342 (1869).

Pratincola albifasciata, Sharpe, Cat. B. Brit. Mus. iv. p. 198 (1879); Salvad. Ann. Mus. Genov. (2) i. p. 166 (1884), vi. p. 262 (1888).

a. 0 ad. Sheik Mahomed, Nov. 7, 1894. Iris dark brown.

This species was found by Rüppell in the mountains of Semien in Abyssinia. Mr. Blanford procure it near Adigrat and again on Lake Ashangi, Antinori and Ragazzi in Shoa from September to January, and the latter naturalist at Kundi in June. Antinori says that it inhabits the high districts of 2000 or 3000 metres, but is also found in the "Kolla" of Mahal-Uonz, Ascaelna, and LetMaratrà.

\section{Fam. Timelims.}

\section{Crateropus suithi.}

Cruteropus smithi, Sharpe, Bull. B. O. Club, iv. p. xli (1895).

C. similis C. hartlaubi et uropygio albo, sed loris et regione periophthalmica albis, regione parotica clare cinerea, nec brunnea, et gutturis pectorisque plumis cinereis, nec brunneis, albido squamulatim marginatis. Long. tot. $10 \cdot 2$ poll., culm. $0 \cdot 8$, alce $4 \cdot 15$, caudae $4 \cdot 5$, tarsi $1 \cdot 3$.

a. + ad. Sheik Husein, Sept. 30, 1894. Iris bright red; legs grey.

b. $\delta$ ad. Darro Mountains, Nov. 18, 1894. Iris greyish brown; legs brown.

This species belongs to the white-rumped section of the genus Crateropus, and is allied to ${ }^{\circ}$. hurtlaubi, but is very distinct from that species. The white lores and hoary face distinguish it at a glance, and the grey feathers of the throat and breast, with their white margins, are also a conspicuous feature. The flanks are strongly fulvescent, and the general aspect of the upper surface is darker than in $C$. hartlaubi, the tail especially being almost black.

\section{ARgYa RUBiginosa.}

Argya rubiginosa (Rüpp.) ; Heugl. Orn. N.O.-Afr. i. p. 390 (1869); Sharpe, Cat. B. Brit. Mus. vii. p. 391. 
Argya heuglini, Sharpe; Oust. Bibl. École Hautes Études, xxxi. art. 10 , p. 5 (1886).

a. $\delta$ ad. Shebeli, Aug. 27, 1894. Iris straw-yellow.

This I take to be the true $A$. rubiginosa of Rüppell. The bird usually called $A$. rubiginosa by African authorities is that which I have called A. heuglini (Cat. B. vii. p. 391), as the name of rufescens proposed for it had been preoccupied by Blyth. I had not noticed that Heuglin himself had discovered his mistake and in his 'Appendix' to the 'Ornithologie Nordost-Afrika's' (iv. p. cecxii) renamed the species $A$. rufula, which name has been adopted by Dr. Reichenow (Vög. Deutsch-Ost-Afr. p. 219), who unearthed Heuglin's identification. On looking over our series, however, I find that there are three species of these rufouscoloured Argya, which may be characterized as follows :-

a. Lores grey or dusky.

$a^{\prime}$. Larger; dark brown above; forehead dark grey, extending to beyond the line of the eyes; hindneck and mantle also dark brown with dark shaftlines quite distinct: wing 3.8 inches

rubiginosa. (Shoa
and Somali.)

$\dot{b}^{\prime}$. Smaller; light brown above; a narrow frontal line of grey; hind-neck light brown, but the dark shaft-lines not distinct, except on the forehead: wing 3.35 inches

rufula. (Equatorial Africa.)

b. Lores vinaceous rufous, like the sides of the face and the under surface of the body saturata. (E. Africa.)

Hence arises a curious confusion of synonymy. Heuglin duly noticed the difference between $A$. rubiginosa and $A$. rufescens, but as the latter name was preoccupied, I proposed to call it $A$. heuglini, but at the same time I described the bird from Zanzibar, which now proves to be distinct from A.rufula (i. e., A.rufescens, Heugl., nec Blyth).

The name of the Zanzibar bird will therefore be

Argia saturati, n. sp.

Argya rufula, auct., ex Africa Orientali (nec Heuglin).

Argya heuglini, Sharpe, Cat. vii. p. 391 (pt. deser. nec syn.).

We have now several specimens of $A$. rufula, Heugl., and of A. saturata in the Museum collection, and the rufous lores and sides of face in the latter species are very pronounced.

\section{Fam. Pycnonotide.}

\section{Pycnonotus dodsoni, n. sp.}

P. similis P. layardi, sed multo minor, nigredine capitis gutturisque valde definita, et rectricibus albo terminatis, pectore et abdomine pure albis, propectore albo, plumis medialiter suturate brunneo notatis, quasi squamatis, et dorsi plumis medialiter nigricantibrunneis squamulatim notatis distinguendus. Long. tot. $6 \cdot 5$ poll., culm. $0 \cdot 6$, alce $3 \cdot 25$, caudce $2 \cdot 6$, tarsi $0 \cdot 75$, 
a. Ad. Sillul, Aug. 8, 1894. Iris black.

b. of ad. Lammo, Aug. 12, 1894.

c. + ad. Dada, Nov. 21, 1894 . Iris brown.

Dr. Reichenow (Vög. Deutsch-Ost-Afr. p. 207) says that Pycnonotus minor, Heugl., has been procured at Itále in German East Africa, and I expected to find that the small Bulbul collected by Dr. Donaldson Smith would prove to be Heuglin's species, which is said to differ from P. layardi in having the head and throat blackish brown instead of black, and not sharply defined from the colour of the back and chest. The under surface of the body is also whiter.

The last-named character is the only one which is found in the Somali Bulbul. The black of the head and throat is as well defined as in P. layardi, and contrasts with the brown of the neck and lower throat. The feathers of the upper surface have blackish-brown centres, which give a mottled appearance to the back; and the fore-neck is white, with blackish centres to the feathers, giving a scaly appearance which is very strongly rarked. The ends of the tail-feathers are also very conspicuously white.

\section{Phyllostrophus pauper, n. sp.}

Similis P. strepitanti, Reichen., sed brunneus, minime olivascens : uropygio rufescente et cauda saturate brunnea distinguendus. Long. tot. $7 \cdot 2$ poll., culm. $0 \cdot 65$, alce $3 \cdot 0$, caudae $3 \cdot 15$, tarsi $0 \cdot 85$.

a. $q$ ad. Shebeli, Aug. 28, 1894. Iris red.

The brown tail and the absolute want of any olive shade in the plumage seems to distinguish this species from $P$. strepitans, of which the Museum possesses specimens from Nyassa-land, identified by Dr. Reichenow.

\section{Fam. Muscicapide.}

\section{Pachyprora pUella.}

Batis puella, Reichen. JB. Hamb. Wiss. Anst. x. p. 18 (1893); id. Vög. Deutsch-Ost-Afr. p. 150.

a. $\delta$ ad. Hargeisa, July 21, 1894.

$b$. o. Okoto, Sept. 8, 1894. Iris yellow; ring next to the pupil thin, reddish brown.

The difficulty of preserving these little Flycatchers renders it by no means easy to determine the extent of the white eyebrow encircling the head. It is very seldom that good skins of the small Pachyprorce are obtainable; and although the pair sent by Dr. Donaldson Smith are in good condition, I cannot definitely trace a complete band of white round the crown. In every other respect they seem to be true $P$. orientalis; but $I$ think that the want of a definite eyebrow is a character of importance, and so I have referred them to $P$. puella of Reichenow, though the median throatmark in the female is not so clearly defined as in Dr. Reichenow's figure (op. cit. fig. 69). 


\section{Muscicapa grisola.}

Muscicapa grisola, L.; Heugl. Orn. N.O.-Afr. i. p. 439 (1871); Sharpe, Cat. B. Brit. Mus. iv. p. 151 (1879).

a. $\sigma^{*}$ ad. Sheik Husein, Sept. 28, 1894. Iris dark brown.

The Common Flycatcher visits Egypt in August and September, and is said by Heuglin to extend southwards to Nubia, Senar, and Abyssinia. In October he found it not rare on the Adel and Somali coasts, and at Aden in December. Neither Antinori nor Ragazzi appear to have met with the species in Shoa, nor did Mr. Jackson meet with it on his journey to Uganda ; but in German East Africa the species has been detected in all kinds of localities from the coast to the Victoria Nyanza, so that there is not the slightest doubt that the species migrates throughout the whole country between the lakes and the coast-region.

\section{Parisoma Boehmi.}

Parisoma boehmi, Reichen. J. f. O. 1882, p. 200 ; id. Vög. Deutsch-Ost-Afr. p. 215 (1894).

a. $\delta$ ad. Hargeisa, July 16, 1894. Iris straw-colour.

This interesting species, which Dr. Reichenow considers to be a Tit, but which I think to be a Flycatcher, has not yet been found in British East Africa or in Shoa, but is recorded by Dr. Reichenow from Ugógo, Wembaere, Mpwápwa, Parè Mountains, and Masailand. Its presence in Somali-land was therefore unexpected, but it doubtless occurs in the intervening region.

\section{Terpiphone cristata.}

Terpsiphone melanogastra (Swains.); Heugl. Orn. N.O.-Afr. i. p. 441 (1871).

Terpsiphone cristata, Sharpe, Cat. B. Brit. Mus. iv. p. 354 (1879); Salvad. Ann. Mus. Genov. (2) i. p. 124 (1884); Shelley, Ibis, 1885, p. 400; Salvad. Ann. Mus. Genov. (2) p. 234 (1888); Sharpe, Ibis, 1892 , p. 504.

a. o ad.; b. o imm. Shebeli, Aug. 26, 1894. Iris brown; eyelids bright blue; legs and bill bluish grey.

c. ơ juv. Sheik Husein, Sept. 19, 1894. Iris brown ; legs grey.

d. त imm. Darro Mountains, Nov. 18, 1894. Iris brown; bill, eyelids, and legs bright grey.

e. $\delta$ ad. ? , Jan. 10, 1895. Iris brown; bill and legs bluish grey.

Heuglin says that the home of this Paradise Flycatcher extends from the Abyssinian coast-land in lat. $16^{\circ}-17^{\circ}$ south to the upper districts of the White Nile and its tributaries. In the wooded portions of Abyssinia it ascends to 8000 feet, and is plentiful in that country, as also in Senar and in Southern Kordofan, on the Sobat, Djur, and Gazelle Rivers, as well as on the Bahr-el-Djebel. Antinori considered the species to be resident, but Heuglin believes that it may be partly migratory, moving at 
certain seasons to the neighbourhood of the waters. Antinori collected a series of specimens in Shoa, from March to December; and as Dr. Ragazzi procured the species in February, it may be taken as a resident in Shoa throughout the year. Mr. Jackson met with it at Turquel in December, and also in the Teita district; but, curiously enough, the species is not included by Dr. Reichenow in his list of the birds of German East Africa, where Terpsiphone emini is recorded from Bukoba, and the South-African T. perspicillata is the predominant species.

\section{Fam. Hirundinide.}

100. Hirundo ethiopica.

Hirundo albigularis (nec Strickl.); Heugl. Orn. N.O.-Afr. i. p. 153 (1869).

Hirundo athiopica, Blanf.; Oust. Bibl. École Hautes Études, xxxi. p. 5 (1886); Sharpe, Cat. B. Brit. Mus. x. p. 146 (1885); Salvad. Ann. Mus. Genov. (2) vi. p. 230 (1888); Reichen. Vög. DeutschOst-Afr. p. 146 (1894).

a. of ad. Hargeisa, July 20, 1894.

b. 우 ad.; c. ơ juv. Luku, Sept. 17, 1894. Iris dark brown.

Occurs, according to Heuglin, all along the Nile below $20^{\circ}-21^{\circ}$ N. lat., and in Abyssinia up to 10,000 feet. On the Red Sea it is less common, but in Bogos-land it is migratory, arriving with the first summer rain and remaining till September. Antinori records it from the same country as arriving in May and leaving in August. Antinori appears never to have met with the species in Shoa, but Dr. Ragazzi procured a young bird at Gascià Mulu in July. It has not occurred in Mr. Jackson's collections, but is recorded by Dr. Reichenow from Bagamoyo.

\section{Order PICIFORMES.}

Fam. Picide.

\section{Thripias SCHOENSIs.}

Picus schoensis, Rüpp.; Heugl. Orn. N.O.-Afr. i. p. 809 (1871). Thripias schoensis, Hargitt, Cat. B. Brit. Mus. xviii. p. 308 (1890).

a. ơ ad. Dada, Nov. 21, 1894. Iris dark red.

This species was discovered by Rüppell in Shoa, and was obtained by Heuglin in the woods on the Bongo and Wau Rivers. Antinori and the Italian naturalists who succeeded that great explorer in Shoa never met with the species. In Teita, Mr. Jackson obtained the southern form, T. namaquus (Sharpe, Ibis, 1891, p. 308), and it is this species which Dr. Reichenow records from Usegúha, Nguru, Aruscha, Ugógo, and Kakoma (Vög. Deutsch-Ost-Afr. p. 121).

102. Dendropicus Hemprichi.

Picus hemprichi, H. \& E. ; Heugl. Orn. N.O.-Afr. i. p. 804 (1871)

Dendropicus hemprichii, Shelley, Ibis, 1885, p. 393; Hargitt, 
Cat. B. Brit. Mus. xviii. p. 299 (1890); Salvad. t. c. p. 552 (1894 : Webbe, Valley of Habir).

Ipoctonus hemprichii, Salvad. Ann. Mus. Genov. (2) vi. p. 211 (1888).

a. $\delta$ ad. Hargeisa, July $20,1894$.

b. + ad. Tooloo. Nov. 24, 1894. Iris red; bill and legs grey.

Not rare, according to Heuglin, on the Abyssinian and Adel coasts, to Senar and Kordofan and on the Lower White Nile. In Central Abyssinia and Gala-land he found it up to 10,000 and 11,000 feet. Dr. Ragazzi met with the species at Cialalakà in Shoa in June, but it does not extend to the south, as it is wanting in Mr. Jackson's collections, and is not recorded from German East Africa by Dr. Reichenow.

\section{CAMPOTHERA NUBica.}

Picus nubicus, Gm.; Heugl. Orn. N.O.-Afr. i. p. 811 (1871). Campothera nubica, Shelley, Ibis, 1885, p. 393 ; Hargitt, Cat. B. Brit. Mus. xviii. p. 93 (1890); Salvad. t. c. p. 552 (1894: Mandera); Sharpe, Ibis, 1892, p. 307; Reichen. Vög. DeutschOst-Afr. p. 121 (1894).

Stictopicus nubicus, Salvad. Ann. Mus. Genov. (2)i. p. 88 (1884), vi. p. 211 (1888).

a. $q$ imm. Hargeisa, July 18, 1894.

b. o ad. Sassabanna, July 31, 1894 . Iris red.

c. Ad. Shebeli, Aug. 26, 1894 . Iris dirty grey; legs grey.

d. Ad. Shebeli, Aug. 29, 1894. Iris crimson; legs pale sagegreen.

According to Heuglin, this Woodpecker is pretty common in Takah, South Nubia, Kordofan, Senar, Abyssinia, and in the Samhar district. It is resident. Antinori says that he never found the species in the highlands of Shoa; in the base of the "Kolla" it is rare, but is met with there, and in similar localities in Somaliland it is common. Dr. Ragazzi collected specimens at DinghaiMeseghia in March, at Ambo-Karra in May, and at Daimbi in June ; Mr. Jackson found the species on Mount Elgon, at 6000 feet, in February; and Dr. Reichenow records it from the Pangani River, Usarámo, Irangi, the eastern slope of Kilima-njaro, and Mpwápwa.

\section{Order SCANSORES.}

\section{Fam. Indiontoride.}

\section{INDICATOR INDICATOR.}

Indicator sparmannii, Stephens; Heugl. Orn. N.O.-Afr. i. p. 767 (1871); Salvad. Ann. Mus. Genov. (2) i. p. 90 (1884).

Indicator indicator (Gm.); Shelley, Cat. B. Brit. Mus. xix. p. 5 (1891) ; Sharpe, Ibis, 1892, p. 308 ; Reichen. Vög. Deutsch-OstAfr. p. 112 (1894). 
a. i imm. Sassabanna, July $31,1894$.

b. of ad. Stonybrook, Aug. 19, 1894. Iris light brown.

c. + ad. Shebeli, Aug. 29, 1894.

Found by Heuglin in the Abyssinian lowlands and the Bogos district. Antinori procured the species at Ambo-Karra in Shoa in Mareh, Mr. Jackson in the Ukanbani country in February, and Dr. Reichenow records it from the Pangani River, Kakoma, Igónda, Ussure, Irangi, and Ugalla.

\section{Fam. Capitonide.}

\section{TrachyphoNuS SHeLLEYI.}

Trachyphonus erythrocephalus (nec Cab.), Shelley, Ibis, 1885, p. 394 (Somali plateau); Salvad. Mem. R. Accad. Torino, (2) xliv. p. 551 (1894).

a. $\&$ ad. Milmil, July 26, 1894.

$b$. $\delta$ ad. Darro Mountains, Nov. 19, 1 94. Iris brown; bill pale reddish brown.

Compared with the type this bird is much larger. It measures total length $8 \cdot 2$ inches, culmen $1 \cdot 0$, wing $3 \cdot 5$, tail $3 \cdot 1$. In $T$. shelleyi the culmen is $0 \cdot 85$, wing $3 \cdot 1$, tail $2 \cdot 8$.

The female appears to differ from the female of $T$. erythrocephalus in having the base of the forehead sulphur-yellow continued into a broad eyebrow, and in having more sulphur-yellow on the fore part of the cheeks and throat.

\section{Trachyphonus uropygialis.}

Trachyphonus uropygialis, Salvad. Mem. Accad. Tor. (2) xliv. p. 551 (1894).

a. $\subsetneq$ ad. Dabulli, Sept. 16, 1894. Iris dark brown; cere black; bill greyish horn-colour; legs grey.

Count Salvadori has separated this species on account of the lateral upper tail-coverts being crimson; but all our six specimens of $T$. boehmi in the British Museum show this peculiarity, and I very much doubt if $T$. uropygialis is distinct. The Somali bird has, however, the rump sulphur-yellow, with minute spots of black, which are not seen in $T$. boehmi, but are apparent in $T$. arnaudi.

\section{Tricholema stigmatothorax.}

Tricholama stigmatothorax, Cab.; Shelley, Ibis, 1885, p. 394 ; id. Cat. B. Brit. Mus. xix. p. 29, pl. ii. fig. i (1821); Sharpe, Ibis, 1892 , p. 509 ; Reichen. Vög. Deutsch-Ost-Afr. p. 116 (1894).

a. Ad. Sillul, Aug. 6, 1894 . Iris black; legs dark slatecolour.

This species was not known to Heuglin or the Italian explorers of Shoa, but was found by Mr. Jackson in the Teita country, and is recorded by Dr. Reichenow from the Pangani and Ronga Rivers, Nguruman, Aruscha, and the eastern slope of Kilima-njaro. 


\section{Order PSITTACIFORMES.}

Fam. Psittacide.

\section{Peocephalus rufiventris.}

Pionias rufiventris (Rüpp.); Heugl. Orn. N.O.-Afr. i. pt. 2, p. 741 .

Poocephalus rufiventris, Salvad. Ann. Mus. Genov. (2) i. p. 78 (1884), vi. p. 207 (1888); id. Cat. B. Brit. Mus. xx. p. 372 (1891); Shelley, Ibis, 1885, p. 393 (Somali tableland); Sharpe, lbis, 1891, p. 311 ; Salvad. Mem. R. Accad. Torino, (2) xliv. p. 551 (1894: S. of Mt. Goolis); Reichen. Vög. Deutsch-Ost-Afr, p. 99 (1894).

a. ơ. Boholgarshan, July 15, 1894.

$b$, c. ơ ㅇ․ Hargeisa, July 17, 1894.

According to Heuglin, this Parrot lives in flocks in the warmer parts of Shoa, for instance on the Eifat, as well as on the Somali plateau southwards from $6^{\circ} \mathrm{S}$. lat. It apparently comes to the Upper White Nile. It is not a highland species, and scarcely extends beyond 4000 to 6000 feet.

In Shoa, Antinori says that it is a bird of the plains and scarcely visits the elevated "Kolla." Mr. Jackson procured the species in the Teita district, and Dr. Reichenow records it from the Pangani and Ronga Rivers, at Parè and in Masai-land.

\section{Order COCCYGES.}

Fam. Cuculide.

\section{Cuculus canorus.}

Cuculus canorus, L. ; Heugl. Orn. N.O.-Afr. i. p. 779 (1871); Salvad. Ann. Mus. Genov. (2) i. p. 93 (1884); Shelley, Cat. B. Brit. Mus. xix. p. 245 (1891); Reichen. Vög. Deutsch-Ost-Afr. p. 110 (1894).

a. Juv. Sheik Mahomed, Nov. 7, 1894. Iris brown; eyelids, legs, and corners of mouth yellow; bill black, shading through green to yellow at the corners of the mouth.

Heuglin records the Common Cuckoo as a plentiful migrant throughout N.E. Africa, passing in spring and autumn. From March to the early part of May it comes to Egypt from the south, and in August is on its way back again, and he obtained a specimen in Bogos-land at the end of July. The species is not, however, often met with during its migrations, and Antinori only obtained a single young bird in Shoa in September, and Dr. Fischer in Aruscha. It has not been procured by Mr. Jackson.

\section{Centropus superciliosus.}

Centropus superciliosus, H. \& E. ; Heugl. Orn. N.O.-Afr. i. p. 797 (1871); Salvarl. Ann. Mus. Genov. (2) i. p. 96 (1884), vi. 
p. 215 (1888); Shelley, Ibis, 1885, p. 400 ; id. Cat. B. Brit. Mus. xix. p. 363(1891) ; Reichen. Vög. Deutsch-Ost-Afr.i.p. 107, fig. 40 (1894).

a. $\delta^{*}$ ad. Tooloo, Nov. 25, 1894. Iris crimson; legs grey; bill black.

b. ㅇ ad. Gelaydee, Jan. 13, 1895.

A resident species in N.E. Africa, according to Heuglin, living in pairs in Southern Arabia and the Abyssinian coast-lands to the Anseba Valley, on the Takazié River and on the Blue Nile, in Southern Nubia to the province of Dongola, and in Kordofan. It is common in the "Kolla" country of Shoa, according to Antinori, and Dr. Reichenow records the species from numerous localities from the Pangani River to Bukoba.

\section{Fam. Musophagid e.}

\section{SChizorhis LeUCOGASTER.}

Schizorhis leucogaster (Rüpp.); Heugl. Orn. N.O.-Afr. i. p. 707 (1871); Shelley, Ibis, 1885 , p. 400 ; Salvad. Ann. Mus. Genov. (2) i. p. 90 (1884), vi. p. 216 (1888); Shelley, Cat. B. Brit. Mus. xix. p. 452 (1891); Sharpe, Ibis, 1892, p. 314; Salvad. Mem. R. Accad. Torino, (2) xliv. p. 552 (1894: Odeuin, Webbe R.); Reichen. Vög. Deutsch-Ost-Afr. p. 102 (1894).

a. $\delta$ ad. Milmil, July $27,1894$.

b. 우 ad. Okoto, Sept. 8, 1894 . Iris dark brown; bill yellowish green, base of ridge yellow-ochre.

c. Ad. Lookoo, Sept. 18, 1894.

d. $\delta$ ad. Hanouttoo, Nov. 20, 1894. Iris brown; bill and legs black.

The "Ahia," writes Heuglin, lives in small families in the warmer valleys of Southern Shoa, where high trees are scattered about, on the Hawasch River, and on the plateau of Somali-land. It is undoubtedly resident. Antinori says that it was common in the woods of Ambo-Karra in Shoa. Mr. Jackson met with it at Turquel and also in the Teita district, and Dr. Reichenow records it from Ussagara, Ugógo, Kakoma, Lake Jipi, Mpwápwa, Aruscha, and Masai-land.

\section{Turacus donaldsoni. (Plate XXVIII.)}

Turacus donaldsoni, Sharpe, Bull. B. O. C. iv. p. xxxii (1895).

a. of ad. Meo, Oct. 25, 1894.

$b$. $\&$ ad. Darro Mountains, Nov. 19, 1894. Iris brown; eyewattle and bill vermilion.

This species bears considerable similarity to Turacus leucotis, in the possession of a white spot in front of the eye and another on the side of the neck ; the colouring of the rest of the body is also the same, but that of the crest is quite different, and, according to Captain Shelley's arrangement of the genus Turacus (Cat. B. xix. 
p. 436), T. donaldsoni would come near the red-tipped species, $T$. meriani and T. fischeri. Both of these species, however, have a band of white below the eye, which is absent in $T$. donaldsoni, while the white spot on the sides of the neck, the leaden-blue colour of the back, and the patch of light crimson which forms the crest are characteristics of the new species.

\section{Order CORACIIFORMES.}

Fam. Coracinde.

113. Coracias lorti.

Coracias lorti, Shelley, Ibis, 1885, p. 399 ; Salvad. Ann. Mus. Gen. (2) vi. p. 224 (1888); Sharpe, Cat. B. Brit. Mus. xvii. p. 20 (1892); Salvad. Mem. R. Accad. Torino, (2) xliv. p. 554 (1894: Webbe and Juba Rivers).

a. of ad. Hargeisa, July 21, 1894.

b. + ad. Stonybrook, Ehrer River, Aug. 19, 1894.

c. $\delta$ ad. Sheik Husein, Sept. 19, 1894. Iris brown; legs yellow-ochre.

d. + ad. Dada, Nov. 21, 1894.

\section{Coracias nevius.}

Coracias pilosa, Lath.; Heugl. Orn. N.O-Afr. i. p. 172 (1869).

Coracias novius, Daud.; Shelley, Ibis, 1885, p. 399 ; Salvad. Ann. Mus. Genov. (2) i. p. 115, vi. p. 223 (1888); Sharpe, Cat. B. Brit. Mus. xvii. p. 24 (1892); id. Ibis, 1892, p. 316 ; Salvad. Mem. R. Accad. Torino, (2) xliv. p. 554 (1894: Aduma); Reichen. Vög. Deutsch-Ost-Afr. p. 124 (1894).

a. $\sigma^{\circ}$ ad. Dabulli, Sept. 16, 1894. Iris brown; eyelid yellowish brown; legs dirty yellow-ochre.

Found, according to Heuglin, on the coast-lands of Abyssinia, in Kordofan, and on the White Nile. From January to August Antinori met with it at Let-Marafia in Shoa, and he says that isolated individuals are met with in the low and middle "Kolla," but it is a bird which loves open country. Mr. Jackson procured the species at Machako's, and Dr. Reichenow gives two localities, Assandaui and Igonda.

\section{Fam. Alcedinide.}

115. Cerrle rudis.

Ceryle rudis (Linn.); Heugl. Orn. N.O.-Afr. i. p. 184 (1869); Salvad. Ann. Mus. Genov. (2) i. p. 112 (1884), vi. p. 222 (1888); Oust. Bibl. Ecole Hautes Etudes, xxxi. art. no. 10, p. 3 (1886); Sharpe, Cat. B. Brit. Mus. xviii. p. 109 (1892); Reichen. Vög. Deutsch-Ost-Afr. p. 130 (1894).

a. of ad. Bainhou, Jan. 10, 1894. Iris brown.

Heuglin states that the Pied Kingfisher is found from the 
Mediterranean coast of Egypt, throughout the whole of the Nile region and on its tributaries, the Kosanga and the Djar Rivers, but becomes rarer on the Upper White Nile than in Egypt and Nubia. It is also found along the Red Sea. In Shoa, Antinori notes the species from the lower and middle "Kolla" country ; and according to Dr. Reichenow it has been met with at Usegúha, Bagamoyo, Ugalla, Kakoma, Pangani, Kagéhi, and the Simiu River, in German East Africa.

\section{IsPIDINA PIOTA.}

Alcedo picta (Bodd.) ; Heugl. Orn. N.O.-Afr. i. p. 183 (1869); Salvad. Ann. Mus. Genov. (2) i. p. 113 (1884), vi. p. 223 (1888).

Ispidina picta, Sharpe, Cat. B. Brit. Mus. xvii. p. 191 (1892); id. Ibis, 1892, p. 316 ; Reichen. Vög. Deutseh-Ost-Afr. p. 133 (1894).

a. + ad. Mount Kuldush, Dec. 18, 1894. Bill and legs orangered; iris brown.

Nowbere common in N.E. Africa, according to Heuglin's notes ; mostly seen in the wood-region up to 7000 feet. He found it in Bogos-land, in Central Abyssinia, and in the steppes of East Senar, Fazogl, \&c.

It is not common in Shoa; Mr. Jackson only met with it once, at Kasamoja, and Dr. Reichenow has only four localities for the species-Dar-es-Salaam, Usegúha, Nguruman, and the Simiu River.

\section{Halcyon semiceruleus.}

Dacelo semicarulea (Forsk.); Heugl. Orn. N.O.-Afr. i. p. 190 (1869).

Halcyon semiccerulea, Salvad. Ann. Mus. Genov. (2) i. p. 113 (1884), vi. p. 223 (1888); Shelley, Ibis, 1885, p. 395; Oust. t. c. p. 4 ; Sharpe, Cat. B. Brit. Mus. xvii. p. 232 (1892); id. Ibis, 1892, p. 317 ; Salvad. Mem. R. Accad. Torino, (2) xliv. p. 553 (1894: Webbe River); Reichen. Vög. Deutsch-Ost-Afr. p. 132 (1894).

a. $\sigma^{*}$ ad.; b. Ad. Gelaydee, Jan. 13, 1895. Bill vermilion; legs dark red; iris brown.

This Kingfisher extends all over the warmer parts of N.E. Africa, and Heuglin gives its northern limit as $16^{\circ} \mathrm{N}$. lat. In October he met with it on the Adail and Somali coast, in Abyssinia to 8000 feet, north to Bogos-land and Takah, on the Blue and White Niles, westward to the Djur district. In Shoa it is said by Antinori to be common in all the woods along the streams of the "Kolla"; Mr. Jackson procured it in the Sük country, and Dr. Reichenow gives many localities from Bagamoyo to Bussissi.

118. Halcyon chelicutensis.

Dacelo tschelicutensis (Stanl.); Heugl. Orn. N.O.-Afr. i. p. 192 (1869).

Halcyon chelicutensis, Oust. Bibl. École Hautes Études, xxxi. Proc. Zoot. Soc.-1895, No. XXXII, 
art. no. 10, p. 3 (1886); Sharpe, Cat. B. Brit. Mus. xvii. p. 239 (1892).

Halcyon chelicuti, Reichen. Vög. Deutsch-Ost-Afr. p. 131(1894).

a. $\delta$ ad. Milmil, July 26, 1894.

Found along the Abyssinian coast-region, and through Abyssinia excepting on the high mountains, and Heuglin also says that he met with the species in Takah, Galabat, and Senar. It has not been met with in Shoa by the Italian travellers, nor by Mr. Jackson in any of his expeditions to Uganda; and Dr. Reichenow only records the species from Kakoma, Ussandani, and Wembere.

Fam. Bucerotide.

\section{LOPHOCEROS HEMPRICHI.}

Buceros hemprichii, Ehr.; Heugl. Orn. N.O.-Afr. i. p. 721 (1869).

Lophoceros hemprichii, Salvad. Ann. Mus. Genov. (2) vi. p. 218 (1888) ; Ogilvie-Grant, Cat. B. Brit. Mus. xvii. p. 405 (1892).

Tockus hemprichii, Salvad. Ann. Mus. Genov. (2) i. p. 103 (1884).

a. $\delta$ ad. Darro Mountains, Nov. 17, 1894. Iris yellowish brown; bill brownish crimson, the under mandible brighter.

In Abyssinia Heuglin states that this species is found in the Dega region from 5000 to 11,000 feet, and says that, if his recollection is correct, he has also received it from the Upper White Nile and from Southern Kordofan. He also records it from Tigré and Ambara, eastwards to the Taranta Pass and Mensa. In Shoa, Antinori says the species is rare in Ambo-Karra, common on the Waina Dega and the Dega. Dr. Ragazzi found it plentiful in the parts of Shoa he visited, but it does not occur in German East Africa.

\section{Lophoceros mediands, n. sp.}

Lophoceros erythrorhynchus?, Salvad. Mem. R. Accad. Torino, (2) xliv. p. 553.

a. Dabulli, Sept. 16, 1894. Iris dark brown; orbits white, shaded with pinkish grey ; bill red, the base white, merging into black on the lower mandible.

I have compared this species with $L$. damarensis, Shelley, and it is so very much smaller than that bird that it cannot be considered identical with it. It has the face white and the broad eyebrow as in $L$. damarensis, but the grey of the crown comes down almost to the base of the bill, so that the forehead is not so pure white as in $L$. damarensis. This character, however, may be variable, but the small size of the Dabulli bird seems to deserve recognition. There is a little shade of grey on the ear-coverts, showing an approach to L. erythrorhynchus; and it is evidently the same species as that procured by Prince Ruspoli on his expedition, on which Count Salvadori has made some apposite remarks. 
The measurements are as follows :-

\begin{tabular}{|c|c|c|c|c|c|}
\hline & $\begin{array}{l}\text { Total le } \\
\ldots \quad 19\end{array}$ & $\begin{array}{c}\text { Culmen. } \\
3 \cdot 45\end{array}$ & $\begin{array}{c}\text { Wing. } \\
7 \cdot 7\end{array}$ & $\begin{array}{l}\text { Tail. } \\
8 \cdot 0\end{array}$ & $\begin{array}{c}\text { Tarsus. } \\
1.7\end{array}$ \\
\hline & - & $3 \cdot 1$ & $7 \cdot 8$ & $7 \cdot 7$ & 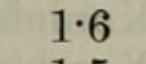 \\
\hline & 15.5 & $2 \cdot 6$ & $6 \cdot 9$ & $7 \cdot 5$ & $1 \cdot 5$ \\
\hline
\end{tabular}

121. LOPHOCEROS FLAVIROSTRIS.

Buceros flavirostris, Rupp.; Heugl. Orn. N.O.-Afr. i. p. 725 (1871).

Tockus flavirostris, Salvad. Ann. Mus. Genov. (2) i. p. 104 (1884), vi. p. 219 (1888).

Lophoceros flavirostris, Ogilvie-Grant, Cat. B. Brit. Mus. xvii. p. 412 (1892); Salvad. Men. R. Accad. Torino, (2) xliv. p. 554 (1894: Webbe Valley); Reichen. Vög. Deutsch-Ost-Afr. p. 128 (1594).

a. $\delta$ ad. Smith River, Sept. 11, 1894. Irides yellow ; orbits black; throat light Indian-red, bluish at the corner of the under mandible; bill bright yellow-ochre, darker at base.

This specimen is true L. flavirostris, and not L. somaliensis of Reichenow (cf. Salvadori, 7 . c.).

According to Heuglin, this Hornbill lives in pairs and families in the hot valleys of Schoholand, frequenting high trees and the Nabag-bushes, which are found in the Bay of Adulis and Samhar, as well as near Moiet Schahadi below Mekulu, but not in the coast-districts proper. It is apparently to be found along the mountain fringes of the Danakil and Adel coasts to Somali-land. Antinori states that it is common on the plains and on the lower "Kolla" of Shoa, but does not ascend to any height. It has occurred at Ndi in the Teita district, to the east of Kilima-njaro, but was not in Mr. Jackson's collections.

122. LOPHOCEROS SIBBENSIS.

Lophoceros sibbensis, Sharpe, Bull. B. O. C. iv. p. xxxii (1895).

a. $q$ ad. Sibbe, Aug. 3, 1894. Iris brown: feet black, the soles yellowish white; bare skin of neck light blue, Indianred next the bill.

123. BuCorax abyssinicus.

Tmetoceros habessinicus (Bodd.) ; Heugl. Orn. N.O.-Afr. i. p. 731 (1871: pt.).

Bucorvus abyssinicus, Salvad. Ann. Mus. Genov. (2) i. p. 101 (1884), vi. p. 217 (1888).

Bucorax abyssinicus, Ogilvie-Grant, Cat. B. Brit. Mus. xvii. p. 349 (1892); Sharpe, Ibis, 1892, p. 317.

a. Ad. Sheik Mahomed, Nov. 5, 1894. Iris dark brown; neck-pouch and orbits bluish grey; patch on base of bill dull red.

Heuglin gives a wide distribution for this species in North- 
eastern Africa. He did not find it in Samhar, but in the neighbouring mountains of Bogos and Habab, as well as in Takah, throughout the whole of Abyssinia south to Shoa, in Fazogl, Senar, Kordofan, and in the district of the White Nile westwards to the Kosanga River. Antinori collected a number of specimens in Shoa, and Mr. Jackson met with the species on the Turquel River ; but in East Africa, according to Dr. Reichenow, it is replaced by B. cafer.

\section{Fam. UPUPIDE.}

\section{UPUPA SOMALENSIS.}

Upupa epops senegalensis (nec Sw.) ; Shelley, Ibis, 1885, p. 397.

Upupa somalensis, Salvin, Cat. B. Brit. Mus. xvi. p. 13, pl. i. (1892).

a. $q$ ad. Hargeisa, July 21, 1894.

\section{IRRISOR ERYTHRORHYNCHUS.}

Irrisor erythrorhynchus (Lath.); Heugl. Orn. N.O.-Afr. i. p. 214 (1869); Salvad. Ann. Mus. Genov. (2) i. p. 107 (1884), vi. p. 220 (1888); Shelley, Ibis, 1885, p. 395 ; Salvin, Cat. B. Brit. Mus. xvi. p. 19 (1892); Reichen. Vög. Deutsch-Ost-Afr. p. 138 (1894).

a. ¿ ad. Shebeli, Aug. 26, 1894 . Iris brown; legs coralred.

c. Ad. Sheik Mahomed, Oct. 28, 1894.

b. + ad. Shebeli, Sept. 3, 1894. Iris brown; legs bright coral-red; base of lower mandible red.

An inhahitant of the wooded country of N.E. Africa, and met with by Heuglin in Takah, Abyssinia, Senar, Kordofan, and in the White Nile districts, westwards to the Kosanga, as well as on the Abyssinian coast-land, ascending the mountains to 1000 feet. Antinori says that the species was common but local at Daimbi in Shoa. It has not occurred to Mr. Jackson in the interior, but Dr. Reichenow gives a number of localities for it in German East Africa-Dar-es-Salaam, Pangani River, Ugogo, Mpwapwa, \&c.

\section{Rhinopomastus minor.}

Irrisor minor (Rüpp.) ; Heugl. Orn. N.O.-Afr. i. p. 218 (1869); Shelley, Ibis, 1885 , p. 397.

Rhinopomastus minor, Salvad. Ann. Mus. Genov. (2) i. p. 263 (1884), vi. p. 220 (1888) ; Salvin, Cat. B. Brit. Mus. xvi. p. 26 (1892); Salvad. Mem. R. Accad. Torino, (2) xliv. p. 553 (1894: River Adadle and Mt. Goolis).

a. $\delta$ ad. The Haud, July 22, 1894.

$b$. $\delta$ ad. Milmil, July 30,1894 . Bill orange.

There seems to be some mistake in the 'Key' to the genus Rhinopomastus given in the 'Catalogue' (p. 24), as R. minor is placed with $R$. cyanomelas in the section with sub-terminal white spots on the tail. As a matter of fact $R$. minor has the tail 
uniform like $R$. cabanisi, which, however, is easily recognized by the absence of the white band on the quills.

Rüppell discovered this Wood-Hoopoe in Shoa, and Antinori met with the species in the country of the Adda Galas, but not in Shoa proper. It has, however, been obtained at Soddé by Dr. Ragazzi. To the south its place appears to be taken by R. cabanisi.

\section{Fam. Meropidx.}

\section{Merops apiaster.}

Merops apiaster, Linn.; Heugl. Orn. N.O.-Afr. i. p. 196 (1869); Salvad. Ann. Mus. Genov. (2) i. p. 107 (1884); Sharpe, Cat. B. Brit. Mus. xvii. p. 63 (1892); id. Ibis, 1892, p. 319 ; Reichen. Vög. Deutsch-Ostafir. p. 135 (1894).

a. $\delta$ ad. Luku, Sept. 18, 1894. Iris reddish brown.

A migrant throughout N.E. Africa, according to Heuglin, from the end of March to the early part of May, and from August to October, mostly in companies. In Arabia Petræa and in Central Egypt he believes that it breeds in May. Antinori met with it in Shoa, passing south in August, and also obtained one specimen in October. It was found by Mr. Jackson in Ukambani and also in Sotik. Dr. Reichenow records it from Dar-es-Salaam, Kakoma, Wualaba, Ugalla, and Igonda.

\section{Merops nubicus.}

Merops nubicus, Gm.; Heugl. Orn. N.O.-Afr. i. p. 199 (1869); Salvad. Ann. Mus. Genov.,(2) i. p. 108, (1884); Shelley, Ibis, 1885, p. 397 ; Oust. Bibl. Ecole Hautes Etudes, xxxi. no. 10, p. 4 (1886); Sharpe, Cat. B. Brit. Mus. xvii. p. 85 (1892); Salvad. Mem. R. Accad. Torino, (2) xliv. p. 552 (1894); Reichen. Vög. Deutsch-Ost-Afr. p. 135 (1894).

$a, b$. + ad. Tooloo, Jan. 13, 1895. Iris dark red.

Heuglin says that this species is found in the warmer parts of Abyssinia, ascending to 6000 or 7000 feet He found it common in Takah, Senar, Kordofan, and along the White Nile, sometimes occurring in flocks of thousands. It breeds at the commencement of the summer rainy season, in the Negro-lands of the Upper Nile in March and April, and in the Eastern Sudan between June and August. Antinori says that in Shoa it is a migrant, passing in small flocks: he obtained it from September to January. Dr. Reichenow records the species from the Pangani River.

\section{Melitrophagus cyanostictus.}

Melittophagus pusillus cyanostictus, Shelley, Ibis, 1885, p. 398. Merops cyanostictus (Cab.); Oust. Bibl. Eecole Hautes Etudes, xxxi. art. 10, p. 4 (1886).

Melittophagus cyanostictus, Salvad. Ann. Mus. Genov. (2) i. p. 110 (1884), vi. p. 221 (1888) ; Sharpe, Ibis, 1892, p. 319 ; id. Cat. B. Brit. Mus. xvii. p. 48, pl. i. fig. 3 (1892) ; Reichen. Vög. Deutsch- 
Ost-Afr. p. 136 (1894); Salvad. Mem. R. Accad. Torino, (2) xliv. (1894 : Hento Valley, Webbe River).

a. $\&$ ad. Near Berbera, July 12, 1894.

b. $\delta$ ad.; c. Ad. Shebeli, Sept. 5, 1894. Iris bright red.

In Shoa, Antinori states, this species is common throughout the year in the lower "Kolla," but does not ascend to any height. Mr. Jackson procured it on Mt. Elgon, and Dr. Reichenow gives a number of localities for the species in German East Africa.

130. Melittophagus revoilit.

Merops (Melittophagus) revoilii, Oust. in Revoil's Faun. et Flor. Çomalis, Ois. p. 5, pl. i. (1882); id. Bibl. École Hautes Études, xxxi. art. 10 , p. 4 (1886).

Melittophagus revoilii, Shelley, Ibis, 1885, p. 398 ; Sharpe, Cat. B. Brit. Mus. xvii. p. 54 (1892).

a. $\delta$ ad. Hargeisa, July 15, 1894.

b. Ad. The Haud, July 25, 1894.

This species is apparently peculiar to Somali-land.

Fam. Colitde.

\section{Colius leucotis.}

Colius leucotis, Rüpp.; Heugl. Orn. N.O.-Afr. i. p. 710 (1871); Salvad. Ann. Mus. Genov. (2) i. p. 100 (1884), vi. p. 217 (1888); Oust. Bibl. Ecole Hautes Etudes, xxxi. art. no. 10, p. 3 (1886); Sharpe, Cat. B. Brit. Mus. xvii. p. 341, pl. xii. fig. 1 (1892); Salvad. t. c. p. 552 (1894: Habir Valley).

a. of ad. Sheik Husein, Sept. 23, 1894. Iris bluish grey; orbits grey ; legs coral-red.

b. Ad. Sheik Husein, Sept. 27, 1894. Iris bluish grey; legs coral-red.

A resident species, according to Heuglin, in the countries of the Beni-Amer, Bogos-land, and the whole of Abyssinia and the Gala countries; less common in Southern Senar, Fazogl, on the Sobat and Upper White Nile to the Gazelle River. Antinori found it in Shoa in small companies ascending to the higher elevations and breeding; but it is not in Mr. Jackson's collections, nor mentioned in Dr. Reichenow's work.

\section{Colius macrurus.}

Colius macrourus (Linn.); Heugl. Orn. N.O.-Afr. i. p. 712 (1871).

Colius macrurus, Oust. Bibl. École Hautes Études, xxxi. art. 10, p. 3 (1886); Sharpe, Cat. B. Brit. Mus. xvii. p. 345 (1892); Reichen. Vög. Deutsch-Ost-Afr. p. 105 (1894).

$a, b$. of $q$ ad. Boholgarshan, July 15, 1894. Iris and cere crimson.

This Coly is found, according to Heuglin, in Southern Nubia and Takah, from about $17^{\circ} \mathrm{N}$. lat. southwards. It occurs in Bogos- 
land, the lowlands of Abyssinia, extending up to 7000 feet, Senar and Kordofan, but does not go far south along the White Nile. It has not been recorded from Shoa, but Dr. Reichenow gives the Pangani River as a single locality for the species in East Africa.

\section{Fam. CapRIMUlgide.}

\section{Caprimulgus inornatus.}

Caprimulyus inornatus, Heugl. Orn. N.O.-Afr. i. p. 129 (1869); Hartert, Cat. B. Brit. Mus. xvi. p. 556 (1892) ; Sharpe, Ibis, 1892, p. 322 ; Reichen. Vög. Deutsch-Ost-Afr. p. 139 (1894).

a. of ad. Zeila, June 30, 1894.

Heuglin found this Goatsucker not uncommon during the rainy season in Bogos-land, where also Messrs. Blanford and Jesse collected it. Heuglin also procured a specimen near Tedjura on the Adail coast. Mr. Jackson met with the species at Makarunga, and Dr. Reichenow records it from Kigonge in Usaramo.

134. Caprimulgus donaldioni.

Caprimulgus donaldsoni, Sharpe, Bull. B. O. Club, iv. p. xxix (1895).

a. Ad. Hargeisa, July 18, 1894.

This fine species of Goatsucker with its long rictal bristles, its red collar round the hind-neck, mottled with golden-buff spots, with a similar collar across the fore-neck, is very distinct from all other African Goatsuckers, and Mr. Hartert pronounces it unquestionably a new species.

\section{Fam. Cypselide.}

135. TACHORNIS PARVA.

Cypselus parvus, Licht.; Heugl. Orn. N.O.-Afr. i. p. 144 (1869). Tachornis parva (Licht.); Hartert, Cat. B. Brit. Mus. xvi. p. 463.

a. + ad. Shebeli, Aug. 28, 1894.

Heuglin says that this Swift is resident in Southern Egypt, in Nubia, and along the White and Blue Niles, becoming rarer in the Gazelle River district. He believes that he saw it also on the Arabian coast and the Dahlak Islands, but not in the Abyssinian Mountains.

\section{Bubo lacteus.}

\section{Order STRIGES.}

Fam. Bubonide.

Bubo lacteus (T.); Heugl. Orn. N.O.-Afr. i. p. 112 (1869); Sharpe, Cat. B. Brit. Mus. ii. p. 33 (1875); Shelley, Ibis, 1885, p. 392 (Ogadayn); Salvad. Ann. Mus. Genov. (2) vi. p. 206 (1888); Oust. t. c. p. 31 (1886); Sharpe, Ibis, 1892, p. 534 ; Salvad. Mem. R. Accad. Torino, (2) xliv. p. 550 (1894: Warandab); Reichen. Vög. Deutsch-Ost-Afr. p. 96 (1894). 
$a, b$. 우 ㅇ․ Sheik Mahomed, Nov. 1, 1894. Iris dark brown.

According to Heuglin, this large Owl is widely distributed throughout the wooded regions of North-eastern Africa. It is pretty common on the Abyssinian coast-lands, in Takah, on the White and Blue Niles, and ascends high up the Abyssinian mountains. It is not common in Shoa, according to Dr. Ragazzi, but was met with in Turquel by $\mathrm{Mr}$. Jackson, and is recorded by Dr. Reichenow from Tabora, Tanga, the Sigi River, and the southern shores of the Victoria Nyanza.

137. Carine spilogastra.

Athene spilogaster, Heugl. Orn. N.O.-Afr. i. p. 119, tab. iv. (1869).

Carine spilogastra, Sharpe, Cat. B. Brit. Mus. ii. p. 138 (1875); Salvad. Mem. R. Accad. Torino, (2) xliv.p. 551 (Durei Katabel ed Habir).

Carine glaux (nec Savign.), Shelley, Ibis, 1885, p. 391.

$a, b$. of $q$ ad. Ahdeh, July 14, 1894.

This species was discovered by Heuglin in the Abyssinian coastland, between Umkulu and Harkiko, in July. Though Dr. Smith's specimens are rather darker than the figure given by Heuglin, and the rufous streaks on the underparts are broader, I believe that they really belong to Heuglin's species. This is the opinion of Count Salvadori; and I have re-examined Mr. Lort Phillips's specimen, which Capt. Shelley referred to Carine glaux, and it is undoubtedly $C$. spilo $a s t r a$, as suspected by the Count.

\section{Glaucidium perlatum.}

Noctua perlata (V.); Heugl. t. c. p. 120 (1869).

Glaucidium perlatum, Sharpe, Cat. B. Brit. Mus. ii. p. 209 (1875); Salvad. Ann. Mus. Genov. (2) i. p. 77 (1884); Reichen. Vög. Deutsch-Ost-Afr. p. 97 (1894).

a. $q$ ad. Darro Mountains, Nov. 20, 1894. Iris light yellow; bill greenish yellow.

According to Heuglin this Pigmy Owlet is resident in Abyssinia, Senar, Kordofan, and the White Nile district, its northern limit being the district of the Beni-Amer and Bogos-land. It is found usually singly in the wooded regions, up to 8000 feet. Antinori procured a specimen at Ambo-Karra in Shoa in July, and it is apparently widely distributed in East Africa, as Dr. Reichenow records it from the Pangani and Ronga rivers, Aruscha, Parè, Nguruman, Taiveta, Ugogo, and Mpwapwa.

\section{Order ACCIPITRES. \\ Fam. FALCONIDE.}

139. Polyboroides typicus.

Polyboroides radiatus, Heugl. Orn. N.O.-Afr. j. p. 76 (1869).

Polyboroides typicus, Sharpe, Cat. B. Brit. Mus. i. p. 48 (1875); 
Salvad. Ann. Mus. Genov. (2) i. p. 75 (1884), vi. p. 204 (1888); Reichen. Vög. Deutsch-Ost-Afr. p. 85 (1894).

a. $q$ ad. Sheik Mahomed, Oct. 28, 1894. Iris dark brown; face cream-colour mottled with orange; base of bill white; legs pale yellow.

Heuglin found the present species resident in Shoa, Fazogl, Senár, Kordofan, and in the country of the White Nile and its tributaries. It is everywhere rare, and was only observed singly, in June on the Blue Nile, in September and October in Kordofan and on the Lower White Nile, in May in the Dinka and Djur countries in the Gazelle River district. Brehm met with it in August and September on the Blue Nile; Rüppell obtained an example in Shoa, and specimens were also procured there both by Antinori and Ragazzi. Mr. Jackson does not appear to bave met with the species on any of his journeys, but I have seen a very black immature specimen obtained by Mr. Scott Elliot on Ruwenzori. According to Dr. Reichenow, it has been found on Kilimanjaro, and in Usaramo and Walla, and at Kakoma.

\section{Circus macrurus.}

Circus swainsoni, Heugl. Orn. N.O.-Afr. i. p. 105 (1869); Salvad. Ann. Mus. Genov. (2) i. p. 76 (1884), vi. p. 225 (1888).

Circus macrurus, Sharpe, Cat. B. Brit. Mus. i. p. 67 (1874); id. Ibis, 1892, p. 535 ; Reichen. Vög. Deutsch-Ost-Afr. p. 86 (1894).

a. Juv. Sheik Mahomed, Nov. 5, 1894. Iris dark brown; feet and base of bill yellow ; cere grey.

$b$. + ad. Budda, Nov. 11, 1894. Iris yellowish brown; feet light yellow; base of bill yellow.

Common in spring and autumn, according to Heuglin, in Senar, Abyssinia, and Kordofan. Antinori met with the species at Daimbi in Shoa in November and December, and Dr. Ragazzi at Dembi in February. Mr. Jackson procured specimens in Turquel in January, and at Machako's in March; and Dr. Reichenow records the species from Igonda.

\section{Astur sphenurus.}

Nisus badius (nec Gm.), Heugl. Orn. N.O.-Afr. i. p. 70 (1869). Astur sphenurus (Rüpp.), Sharpe, Cat. B. Brit. Mus. i. p. 113 (1874).

Scelospizias sphenurus, Salvad. Ann. Mus. Genov. (2) i. p. 72 (1884).

a. ơ ad̄. Ehrer River, Aug. 18, 1894. Iris red; cere, feet, and eyelids bright yellow.

This species is recorded from the Dahlak Islands by Rüppell, and by Hemprich and Ehrenberg from Arabia. Heuglin collected it on the coast-land of Abyssinia, in Bogos-land, on the Mareb and near Adowa in Tigrié, in the "Quola" of Western Abyssinia, on the Blue Nile near Senar and Khartoum, and along the whole of the White Nile and Gazelle River, westwards to Kosanga in Equatorial 
Africa. It was noticed by Antinori at Daimbi in Shoa in January, but not by Dr. Ragazzi. In the Turquel country Mr. Jackson obtained the Southern race, Astur polyzonoides, which is also the form prevalent in East Africa ( $c f$. Reichen. t. c. p. 88).

\section{Melierax poliopterus.}

Melierax poliopterus, Cab.; Sharpe, Cat. B. Brit. Mus. i. p. 88 ; Salvad. Mem. R. Accad. Torino, (2) xliv. p. 550 (1894); Reichen. Vög. Deutsch-Ost-Afr. p. 86 (1894).

Melierax polyzonus (nec Rüpp.), Oust. Bibl. École Hautes Etudes, xxxi. art. no. 10, p. 2.

a. 0 ad. Doda, Nov. 21, 1894.

$b, c$. Ad. Doda, Nov. 22, 1894. Iris brown; base of bill deep yellow; legs salmon-colour.

This species is not known from Shoa, nor has Mr. Jackson met with it in the interior of East Africa, but Dr. Reichenow records it from Speke Gulf and Irangi.

\section{Melierax gabar.}

Nisus gabar, Heugl. Orn. N.O.-Afr. i. p. 73 (1869).

Melierax gabar (Daud.); Sharpe, Cat. B. Brit. Mus. i. p. 89 (1874); Shelley, Ibis, 1885, p. 391 ; Sharpe, Ibis, 1892, p. 535 ; Reichen. Vög. Deutsch-Ost-Afr. p. 87 (1894).

Micronisus gabar, Salvad. Ann. Mus. Genov. (2) i. p. 72 (1884), vi. p. 203 (1888).

a. $q$ juv. Berbera, July 4, 1894.

$b$. $\sigma^{t}$ ad. Boholgarshan, July 15, 1894. Iris reddish brown.

Heuglin states that the "Gabar" is the commonest Hawk in the cultivated lands and on the islands of the Nile in Nubia and Senar; also on the coast of Abyssinia, on the Mareb, in Takah and Kordofan, but is rare on the Upper White Nile. It was not seen in wooded country or on the Abyssinian highlands. His most northern point for the species was between Wadi-Halfa and Dir ; but according to Schlegel the species has been obtained near Suez. Antinori procured specimens at Daimbi in Shoa in November, and Dr. Ragazzi met with it in the same country in March, June, and August. Mr. Jackson obtained it at Machako's in March and April, and Dr. Reichenow records it from Useguha and Ukamba.

\section{Melierax niger.}

Nisus niger, Heugl. Orn. N.O.-Afr. i. p. 74 (1869).

Melierax niger, Sharpe, Cat. B. Brit. Mus. i. p. 91 (1874); id. Ibis, 1892, p. 535 ; Reichen. Vög. Deutsch-Ost-Afr. p. 87 (1894). Micronisus niger, Salvad. Ann. Mus. Genov. (2) i. p. 73 (1884). a. $q$ ad. Boholgarshan, July 15, 1894. Iris orange.

Heuglin says that this species is often found in localities where M. gabar does not occur, as in Bogos-land, high Central Abyssinia, and on the Upper White Nile, but it was not noticed by him in 
Dongola, where $M$. gabar is the commonest bird of prey. The northern range of $M$. niger is the Bajuda Steppes ; it is resident in Bogos-land and Abyssinia, but was most plentiful in the "Quola" of West Abyssinia, especially in the provinces of Sarago and Qalabat. Antinori met with it at Daimbi in Shoa in May, Mr. Jackson at Turquel in January, and Dr. Reichenow records it from Ukamba.

\section{BUTEO AUGUR.}

Buteo augur, Heugl. Orn. N.O.-Afr. i. p. 92 (1869); Sharpe, Cat. B. i. p. 175 ; Shelley, Ibis, 1885 , p. 391 (30 miles from Berbera); Sharpe, Ibis, 1892 , p. 536; Reichen. Vög. DeutschOst-Afr. p. 93 (1894).

Pterolestes augur, Salvad. Ann. Mus. Genov. (2) i. p. 51 (1884), vi. p. 196 (1888).

a. $q$ ad. Sheik Mahomed, Nov. 5, 1894. Iris golden brown; base of bill and corners of mouth dark greenish yellow; legs light dull yellow.

b. + ad. Budda, Nov. 11, 1894. Iris rich brown; legs and base of bill yellow.

Heuglin says that the Augur Buzzard was found by him from the Taranta Pass, Mensa, and the Tsad-Amba southwards through the whole of Tigrié and Amhara; it is likewise common in Gallaland, very rare on the Blue Nile, in Fazogl and East Senar. On the Tana it was not observed. It is resident, and breeds between 5,060 and 12,000 feet. A very large series of specimens was obtained in Shoa by the Italian naturalists, in nearly every month of the year; Mr. Jackson met with the species in Masai-land in August, in February in Ukambani, and again in the same month on Mount Elgon. Dr. Reichenow records it in East Africa, from Igónda, Ussukúma, Karagwe, and Kagehi.

146. Aquila rapax.

Aquila rapax (Temm.); Heugl. t. c. p. 45 (1869); Sharpe, Cat. B. i.p. $242(1874)$; id.Ibis, 1892, p. 537 ; Reichen. Vög. DeutschOst-Afr. p. 92 (1894).

Aquila albicans, Salvad. Ann. Mus. Genov. (2) i. p. 38 (1884), vi. p. 195 (1888).

a. Ad. Sheik Mahomed, Nov. 1, 1894. Iris golden brown; base of bill, upper and under mandible yellow; cere yellowish; feet light yellow.

b. $q$ ad. Darro Mountains, Nov. 20, 1894. Iris rich brown, mottled whitish; base of bill, corners of mouth, and feet yellow.

According to Heuglin, the Tawny Eagle is spread over the greater part of N.E. Africa. In Egypt and Northern Nubia it is rare and only found in winter. It is common in Southern and Eastern Senar, in Takah, Bogos-land, and throughout the whole of Abyssinia, up to 12,000 feet elevation, as well as on the hot 
Samhar coast, as, for instance, in the valleys of Ailat and Azuz. The light form of this Eagle, known as A. albicans, was obtained in Shoa by Antinori, who collected many specimens. Mr. Jackson has found the species in Turquel, and Dr. Reichenow records it from Aruscha.

\section{Helotarsus ecaudatus.}

Helotarsus ecaudatus (Daud.); Heugl. Orn. N.O.-Afr. i. p. 80 (1869); Salvad. Ann. Mus. Genov. (2) i. p. 46 (1884); Reichen. Vög. Deutsch-Ost-Afr. p. 91 (1894).

a. $\delta$ ad. Sheik Husein, Sept. 25. Irides rich brown; sides of face and eyebrows orange, with small vermilion blotches ; bill bright yellow-ochre at the base, shading abruptly into black towards the apex; feet yellow, varying irregularly from straw- to pale salmon-colour.

Heuglin says that he found the Bateleur Eagle from the Bajuda desert and Takah southwards throughout the whole of Abyssinia, on the Danakil and Somali coasts, in Senar, Kordofan, and the district of the Blue Nile ; also on the White Nile and Gazelle River. Antinori records it from the country of the Eisa and Adal Somalis, as well as from Shoa and the Gala country. Mr. Jackson has not yet obtained it, but Dr. Reichenow notes it from Ugalla, Masailand, Wembere, Ussegúha, Kagehi, and the Simiu River.

\section{Eutolma Ëtus spilogaster.}

Spizaëtus spilogaster, Du Bus ; Heugì. Orn. N.O.-Afr. i. p. 57 (1869).

Nisaëtus spilogaster, Sharpe, Cat. B. Brit. Mus, i. p. 252 (1874); Salvad. Ann. Mus. Genov. (2) i. p. 44 (1884).

a. $\delta$ ad. Nov. 22,1894. Bill light grey; feet greenish yellow; iris yellow-ochre.

A male bird in fine adult plumage.

Heuglin says that this species was observed by him in Northeastern Africa in the months of April, May, September, and November, but not during the true winter season. He states that it was nowhere common, but he observed it on the upper Mareb near Gundet, in Hamedo in the province of Tigrié, on the western slope of the Abyssinian highlands near Wohni, and in Qalabat, in East Senar near Doka, and finally on the Blue Nile northwestwards to the neighbourhood of Khartoum. It is not rare at Denz in Shoa, according to Antinori, bnt it has not yet been recorded from East Africa.

\section{Haliaëtus vocifer.}

Haliaëtus vocifer (Daud.); Heugl. t. c. p. 53 (1869); Sharpe, t. c. p. 310 (1874) ; Oust. Bibl. École Hautes Études, xxxi. art. 10, p. 1 (1886); Salvad. Ann. Mus. Genov. (2) i. p. 45 (1884), vi. p. 196 (1888); Sharpe, Ibis, 1892, p. 538 ; Reichen. Vög. DeutschOst-Afr. p. 90 (1894). 


\section{$2 \mathrm{BHL}$ Biodiversity Heritage Library}

1895. "May 21, 1895. Lt.-Col. H. H. GODWIN-AUSTEN, F.R.S., Vice-President in the Chair." Proceedings of the Zoological Society of London 1895, 400-520. https://doi.org/10.1111/j.1096-3642.1895.tb01794.x.

View This Item Online: https://www.biodiversitylibrary.org/item/97158

DOI: https://doi.org/10.1111/j.1096-3642.1895.tb01794.x

Permalink: https://www.biodiversitylibrary.org/partpdf/72791

\section{Holding Institution}

Natural History Museum Library, London

\section{Sponsored by}

Natural History Museum Library, London

\section{Copyright \& Reuse}

Copyright Status: Public domain. The BHL considers that this work is no longer under copyright protection.

This document was created from content at the Biodiversity Heritage Library, the world's largest open access digital library for biodiversity literature and archives. Visit BHL at https://www.biodiversitylibrary.org. 